\title{
Russian Privatization and Corporate Governance: What Went Wrong?
}

By: Bernard Black, Reinier Kraakman and Anna Tarassova

Working Paper Number 269a

May 2000 


\title{
Russian Privatization and Corporate Governance: What Went Wrong?
}

\author{
Bernard Black \\ Stanford Law School \\ Reinier Kraakman \\ Harvard Law School \\ Anna Tarassova \\ IRIS (Institutional Reform and the Informal Sector) \\ University of Maryland, College Park
}

forthcoming in 52 Stanford Law Review ___ (2000)

(this is an almost final version of the to-be-published article)

\author{
Stanford Law School \\ John M. Olin Program in Law and Economics \\ Working Paper No. 178 \\ William Davidson Institute at \\ University of Michigan Business School \\ Working Paper No. 269 \\ This paper can be downloaded without charge from the \\ Social Science Research Network electronic library at: \\ http://papers.ssrn.com/paper.taf?abstract_id=181348
}




\title{
Russian Privatization and Corporate Governance: What Went Wrong? \\ Bernard Black \\ Reinier Kraakman \\ Anna Tarassova*
}

\begin{abstract}
In Russia and elsewhere, proponents of rapid, mass privatization of stateowned enterprises (ourselves among them) hoped that the profit incentives unleashed by privatization would soon revive faltering, centrally planned economies. The revival didn't happen. We offer here some partial explanations. First, rapid mass privatization is likely to lead to massive selfdealing by managers and controlling shareholders unless (implausibly in the initial transition from central planning to markets) a country has a good infrastructure for controlling self-dealing. Russia accelerated the selfdealing process by selling control of its largest enterprises cheaply to crooks, who transferred their skimming talents to the enterprises they acquired, and used their wealth to further corrupt the government and block reforms that might constrain their actions. Second, profit incentives to restructure privatized businesses and create new ones can be swamped by the burden on business imposed by a combination of (among other things) a punitive tax system, official corruption, organized crime, and an unfriendly bureaucracy. Third, while self-dealing will still occur (though perhaps to a lesser extent) if state enterprises aren't privatized, since self-dealing accompanies privatization, it politically discredits privatization as a reform strategy and can undercut longer-term reforms. A principal lesson: developing the institutions to control self-dealing is central to successful privatization of large firms.
\end{abstract}

\footnotetext{
* The authors are, respectively, Professor of Law, Stanford Law School; Professor of Law, Harvard Law School, Senior Legal Advisor, IRIS (Institutional Reform and the Informal Sector),University of Maryland, College Park. We thank Harry Broadman, Jason Bush, Kevin Covert, Richard Craswell, George Crawford, Simeon Djankov, Alexander Dyck, John Earle, David Ellerman, Itzhak Goldberg, Dale Gray, Barry Ickes, Gregory Jedrzejczak, Tarun Khanna, Miriam Klipper, Michael Klausner, Branco Milanovic, David Moss, Peter Murrell, John Nellis, Hugh Patton, Katarina Pistor, Russell Pittman, Gerhard Pohl, Harold Rogers, Andrei Shleifer, Christopher Stone, Lee Wolosky, Alexander Yushkevich, Lena Zezulin, and participants in workshops at the American Law and Economics Association, George Mason Law School, Harvard Business School, an OECD Conference on Corporate Governance in Russia, the International Monetary Fund, Stanford Center for Russian and East European Studies, Stanford Law School, University of California - Berkeley ( Haas School of Business), University of Michigan (the William Davidson Institute) and the World Bank for helpful discussions and comments. Special thanks to James Fenkner of Troika Dialog for the data on Russian market capitalization and comparable Western values for Russian companies reported in Part III of this article, and to Brian Fonville for research assistance. The research for this article was substantially completed in September 1999; we updated partially through May 2000, primarily to correct statements that were inaccurate by then.
} 


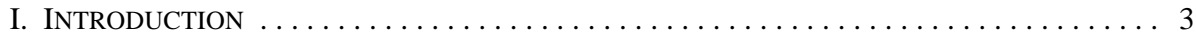

II. A CyNIC's TOUR OF RUSSIAN PRIVATIZATION $\ldots \ldots \ldots \ldots \ldots \ldots \ldots \ldots \ldots \ldots .8$

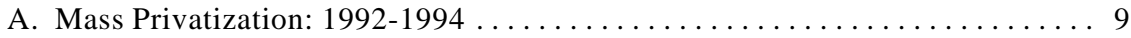

B. "Loans-for-Shares" and Other Rigged Auctions: 1995-Present . . . . . . . 12

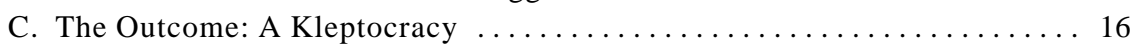

III. Structural Flaws in RUSSIAN Privatization $\ldots \ldots \ldots \ldots \ldots \ldots \ldots \ldots \ldots \ldots$

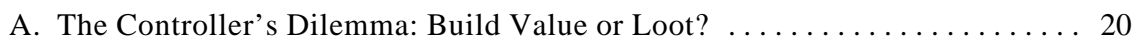

B. Russia's Legal and Institutional Infrastructure $\ldots \ldots \ldots \ldots \ldots \ldots \ldots . \ldots 21$

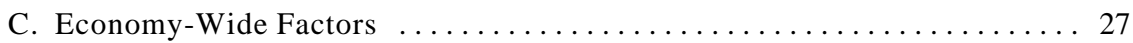

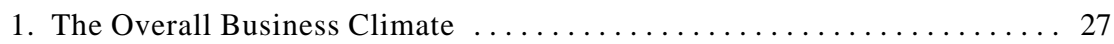

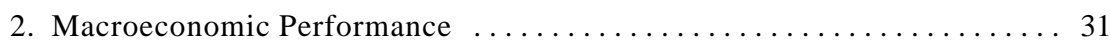

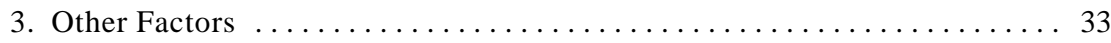

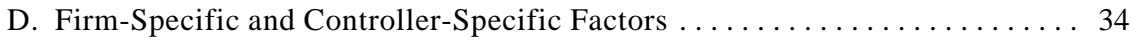

E. Mass-Privatized Enterprises: Manager Theft and Incompetence . . . . . 35

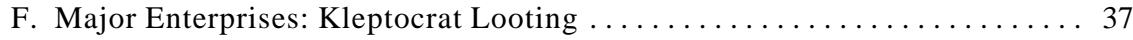

IV. THE COUNTERFACTUAL: W HAT M IGHT HAVEHAPPENEDW ITH STAGED PRIVATIZATION AND MORE INSTITUTION BUILDING? . . . . . . . . . . . . . . . . . . . . 47

A. Did Large-Firm Privatization Make Self-Dealing Worse? . . . . . . . . . . 48

B. The Efficiency and Distributional Consequences of Privatization $\ldots \ldots \ldots 50$

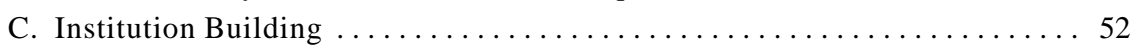

D. Staged Privatization: Enterprise Leasing and Alternatives . . . . . . . 53

1. Enterprise Leasing . . . . . . . . . . . . . . . . . . . 54

2. Other Approaches to Staged Privatization $\ldots \ldots \ldots \ldots \ldots \ldots \ldots \ldots \ldots$

E. The Political Consequences of Dirty Privatization $\ldots \ldots \ldots \ldots \ldots \ldots \ldots 5$

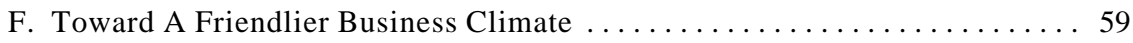

V. InSIDER SELF-DEALING IN THE CZECH REPUbliC $\ldots \ldots \ldots \ldots \ldots \ldots \ldots \ldots \ldots \ldots . \ldots$

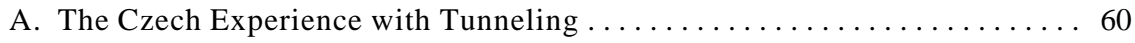

B. Comparing Russia and the Czech Republic .................. 64

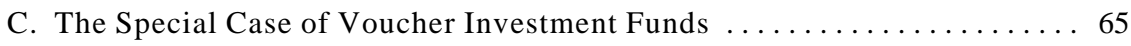

D. A Czech Counterfactual: Mass Privatization with Institution Building . . . 66

VI. IMPLICATIONS FOR FUTURE PRIVATIZATION EFFORTS $\ldots \ldots \ldots \ldots \ldots \ldots \ldots \ldots \ldots$. . . 67

A. Steps Toward Successful Large-Firm Privatization . . . . . . . . . . . . 68

B. The Case for Selective Renationalization and Reprivatization . . . . . . . . . 69

C. Strengthening Product Market Discipline . . . . . . . . . . . . . . 70

D. How Can the Outside World Help Russia? .................. 71

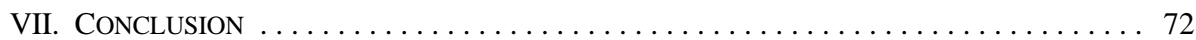

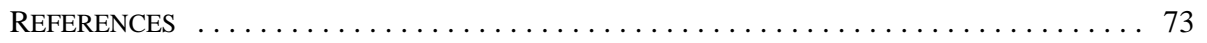




\section{INTRODUCTION}

Rapid mass privatization of state-owned enterprises in formerly centrally planned economies hasn't turned out the way its creators hoped, in Russia or elsewhere. When Russian mass privatization began in the early 1990s, its proponents (including ourselves) hoped that the Russian economy would soon bottom out and then turn upward, as the efficiency incentives unleashed by privatization took hold. ${ }^{1}$ That didn't happen.

Russia's mass privatization "voucher auctions" were moderately honest, but gave control to managers. This permitted insiders (managers and controlling shareholders) to engage in extensive self-dealing (transactions between insiders and the company, in which the insiders profit at the company's expense), which the government did nothing to control. Later privatization "auctions" were a giveaway of Russia's most important companies at bargain prices to a few wellconnected "kleptocrats," who got the funds to buy these companies by skimming from the government and transferred their skimming talents to the enterprises they acquired.

At the macro level, the Russian economy stumbled along through mid-1998, then collapsed again, as it had in 1991-92 prior to privatization. Russia's medium-term prospects are only so-so. The Russian ruble has plunged; the Russian government has defaulted on both its dollar- and ruble-denominated debt, most banks are bankrupt, corruption is rampant, tax collection is abysmal, capital flight is pervasive, and new investment is scarce. The Russian economy rebounded somewhat in 1999 and 2000, but from a greatly shrunken base and mostly because oil prices soared. The fundamentals of nonextractive industries haven't changed that much. It remains to be seen whether Russia's new President, Vladimir Putin, will develop a coherent economic policy-none has emerged in his first year as Prime Minister and then President.

Russia's disappointment with mass privatization is mirrored in other former Soviet Union countries and, less severely, in the Czech Republic, which at one time seemed to be a model of the transition from central planning to a market economy. This suggests that the failure of privatization to jumpstart the Russian

\footnotetext{
1 The best statement of the optimists' view is MAXIM BOYCKO, ANDREI SHLEIFER \& RoBERT ViShNY, PRIVATIZING RUSSIA (1995). Boycko was one of the principal Russian architects of mass privatization. Shleifer and Vishny are American economists who helped to design the Russian mass privatization program. They and their collaborators recruited us (Tarassova beginning in 1992, Black and Kraakman beginning in 1993) to work on the legal infrastructure for Russia's capital markets. One outgrowth of that effort was the current Russian law on joint stock companies, which we have described elsewhere. See Bernard Black \& Reinier Kraakman, A Self-Enforcing Model of Corporate Law, 109 HARV. L. REV. 1911 (1996); BERNARD S. B LACK, REINIER KRAAKMAN \& ANNA TARAssova, Guide to the Russian LaW On Joint StOck COMPANIES (1998).
} 
economy may reflect structural flaws in mass privatization as a transition mechanism, not just Russia's specific circumstances.

This paper joins an emerging literature that questions whether rapid mass privatization of large firms is an important element of the transition from central planning to a market economy. ${ }^{2}$ We develop below a case study of what went wrong with large-firm privatization in Russia, using the Czech Republic as a comparison case study to assess the extent to which Russia's problems are generalizable. We bring to this task a reasonable mix of insiders' knowledge and outsiders' skepticism, gained through experience with privatization and capital markets reform in Russia and other countries. ${ }^{3}$

We leave to others analysis of the macroeconomic steps that Russia might have taken and focus on microeconomic steps related to privatization and capital markets development. But the two are related. Russia's macro effort to balance the budget, control inflation, and attract investment was defeated, in large measure, by the micro failures we discuss below.

We see three main failures in the Russian privatization effort. First, rapid mass privatization of large enterprises is likely to lead to massive insider selfdealing unless (implausibly in the initial transition from central planning to

\footnotetext{
2 Early doubters about rapid privatization include JANOS KoRNAI, THE ROAD TO A FREE ECONomy: Shifting from a Socialist System-The EXAMPle of Hungary (1990); Stephen S. Cohen \& Andrew Schwartz, Privatization in the Former Soviet Empire: The Tunnel at the End of the Light, Amer. Prospect, Spr. 1993, at 99; Peter Murrell, What is Shock Therapy? What Did it Do in Poland and Russia?, 9 PosT-Soviet AfF. 111 (1993); Peter Murrell \& Yijiang Wang, When Privatization Should be Delayed: The Effect of Communist Legacies on Organizational and Institutional Reforms, 17 J. COMP. ECON. 385 (1993). Recent work includes GERARD ROLAND, TRANSITION ECONOMICS: POlitics, MARKeTs AND Firms (forthcoming 2000); David Ellerman, Voucher Privatization with Investment Funds: An Institutional Analysis (World Bank Pol'y Research Paper No. 1924, 1998); Janos Kornai, Ten Years After "The Road to a Free Economy": The Author's Self-Evaluation, working paper presented at the Annual Bank Conference on Development Economics (World Bank 2000); Joseph E. Stiglitz, Whither Reform? Ten Years of the Transition, working paper presented at the Annual Bank Conference on Development Economics (World Bank 1999); John Nellis, Time to Rethink Privatization in Transition Economies?, Fin. \& DeV., June 1, 1999, at 16.

3 Anna Tarassova was a senior legal advisor to the Russian Privatization Ministry during mass privatization and later a senior legal advisor to the Russian Securities Commission. She participated in drafting many of the basic laws and Presidential decrees that support Russia's capital markets. Bernard Black and Anna Tarassova worked together on several Russian capital markets laws and decrees, including joint stock company law, securities law, limited liability company law, and a decree on investment funds; Reinier Kraakman assisted in developing the theoretical structure for the Russian joint stock company law. Black has also been an advisor on privatization, corporate governance, and capital markets legislation in Armenia, the Czech Republic, Indonesia, Mongolia, South Korea, Ukraine, and Vietnam; Kraakman has advised on company law in Vietnam; Tarassova has advised on capital markets and commercial legislation in Armenia, Belarus, Kazakhstan, Macedonia and Ukraine.
} 
markets) a country has a good infrastructure for controlling self-dealing. If control is given to the current managers, as in Russian mass privatization, they often won't know how to run a company in a market economy. Some managers will loot their companies, perhaps killing an otherwise viable company. If outsiders can acquire control in the stock market, as in the Czech Republic, bad owners will often drive out good ones. A controlling stake is worth more to a dishonest owner who will extract all of a firm's value than to an honest owner who will share that value with minority shareholders.

To prevent this outcome, development of a decent legal and enforcement infrastructure must precede or at least accompany privatization of large firms. If privatization comes first, massive theft is likely to occur before the infrastructure to control it can develop. At the same time, important parts of this infrastructure require a base of existing private firms. For example, to learn to prosecute fraud and self-dealing, regulators need some fraud and self-dealing to practice on. Thus, privatization must to some extent be staged, lest the crooks simply outrun the regulators.

In a mythical thick market for corporate control, good owners could buy companies from bad owners if the company was worth more if run honestly than if run to maximize short-run skimming. But in fact, good owners don't exist in Russia in significant numbers or with the capital to buy large enterprises. If they existed, they wouldn't pay a bad owner anything close to fair value, because they couldn't verify what shape the business was in. Moreover, the business might be worth more to the bad owner, who has a comparative advantage in the important tasks of self-dealing, evading taxes, obtaining favors from the government, not paying workers, and using effective albeit unofficial means (read: the Mafia) to enforce contracts and scare off competitors. In contrast, an honest owner risks having the government expropriate his investment.

Second, the profit incentives to restructure privatized enterprises (instead of looting them), and to create new businesses that could draw workers from shrinking enterprises, can be swamped by a hostile business environment. In Russia, that environment included a punitive tax system, official corruption, organized crime, an unfriendly bureaucracy, failure to privatize urban land, and a business culture in which skirting the law is seen as normal, even necessary behavior.

Third, corrupt privatization of large firms can compromise future reforms. In Russia, self-dealing was widespread before privatization began, and would have continued if large enterprises were privatized more slowly. But privatization can make self-dealing easier. In a vicious circle, dirty privatization also reinforces corruption and organized crime, as the new owners (some already with Mafia ties) turn their new wealth to the task of bribing judges and 
government officials. Corrupt officials and company insiders join forces to resist future reforms, while the public comes to see privatization (and, by inference, other market reforms) as connected with self-dealing, corruption, and organized crime.

To be sure, Russia's economic problems weren't caused by privatization. Ukraine offers a sobering example. It hasn't privatized large firms, but is as corrupt as Russia and has done even worse economically. Comparing Russia with Ukraine suggests that if government is bad enough-badly enough corrupted, incapable of sustaining sensible policy-mass privatization won't affect economic performance very much, for better or worse. The assets of state-owned enterprises will be stolen whether they are privatized or not.

Our concerns here are with rapid mass privatization of large enterprises, not with the other elements of the "shock therapy" prescription dispensed by Western advisors. There is much to be said, in the transition to a market economy, for the government rapidly selling or giving away small shops and businesses to the people who work there, and apartments and land to the people who live there. These steps don't entail the separation of ownership and control that encourage self-dealing by controllers of large enterprises. But we believe that a concerted effort to control self-dealing is central to successful large firm privatization. $^{4}$

An important piece of the overall puzzle: The largest Russian companies were sold in massively corrupt fashion to a handful of well-connected men, soon dubbed "kleptocrats" by the Russian press (Russian: 8: , BH@" $>Z$ ), who made their first centimillions or billions through sweetheart deals with or outright theft from the government, and then leveraged that wealth by buying major companies from the government for astonishingly low prices. The "reformers" who promoted privatization regretted the corruption, but claimed that any private owner was better than state ownership. Even if the new owners got their ownership in regrettable ways, they would have incentives to increase company value. Many foreign advisors bought this story, viewed dirty privatization as better than no privatization, and supported Russia's privatization czar, Anatoli Chubais, as he pursued privatization by any available means.

Left unnoticed was that the new owners had two ways to make money-increase the company's value, or steal what value already existed. The first was difficult, perhaps beyond their ability, and uncertain in outcome. The second was easy; they were expert at it; and it was sure to produce a handsome profit that could be tucked away overseas, beyond the reach of a

${ }^{4}$ We do not assess in this paper where the line should be drawn between small enterprises, for which rapid privatization seems desirable, and large enterprises, for which it is problematic. 
future Russian government. Most of the kleptocrats chose the second, easy approach.

An example: Bank Menatep (controlled by kleptocrat Mikhail Khodorkovski) acquired Yukos, a major Russian oil holding company, in 1995. For 1996, Yukos' financial statements show revenue of $\$ 8.60$ per barrel of oil-about $\$ 4$ per barrel less than it should have been. ${ }^{5}$ Most of the missing revenue likely ended up in offshore bank accounts controlled by $\mathrm{Mr}$. Khodorkovski and his accomplices. Khodorkovski skimmed over 30 cents per dollar of revenue while stiffing his workers on wages, defaulting on tax payments, destroying the value of minority shares in Yukos and its production subsidiaries, and not reinvesting in Yukos' oil fields.

It's doubtful that running Yukos honestly could have earned Khodorkovski a fraction of what he earned by skimming revenue, let alone offshore and taxfree. He made a rational, privately value-maximizing choice. Even if running Yukos honestly was the best long-run strategy, Khodorkovski might have preferred present profit over future uncertainty. Besides, skimming was a business that he knew, while oil production was a tough business that he might fail in.

This example illustrates a general point: Privatization is not enough. It matters who the owners are, what constraints on self-dealing they face, and the business climate they operate in. If it isn't politically feasible to import foreign owners, who are more likely to run privatized businesses honestly (though foreign owners must be watched too, as the Czechs learned) and to invest if profit opportunities exist, the government's second-best choice may be to first privatize selected firms with strong profits and reputedly honest managers, and watch these firms carefully once they are privatized, while building the legal and market institutions to control self-dealing. ${ }^{6}$

Even without immediate privatization, managers can be motivated to restructure by the promise of running a company that will be privatized if profitable. The government's ability to control theft will be higher if the enterprise is still state-owned. And the enterprise's sale price will be far higher

5 This assumes that Yukos exported roughly 25\% of its production, at world prices of around $\$ 18 /$ barrel, and sold the balance at domestic prices of around $\$ 10.50 /$ barrel. Yukos revenue is based on translated Yukos financial statements provided to us by Graham Houston of National Economic Research Associates. Houston's numbers are also reported in Jeanne Whalen, Shareholders Rights: Round 2, Moscow Times, Feb. 17, 1998.

${ }^{6}$ It is beyond the scope of this article to discuss which institutions were most important. That topic is addressed in Bernard S. Black, The Legal and Institutional Preconditions for Strong Securities Markets, 48 UCLA L. REV. (forthcoming 2000), available in Social Science Research Network at <http://papers.ssrn.com/paper.taf?abstract_id=182169>. 
if it is sold in a stronger legal environment, in a fairer auction, and perhaps with more foreign participation than was politically acceptable in the near term. Ironically, Russia had such a "staged privatization" program in place in the early 1990s, through a program called enterprise leasing. The privatizers killed enterprise leasing because they thought it wasn't fast enough.

Proponents of fast privatization may respond that there is no assurance that the infrastructure to control self-dealing will develop anytime soon. This is indeed a risk. But the right response may be to stage privatization and work hard to develop this infrastructure, rather than privatize large firms anyway and hope that the outcome will somehow be acceptable.

Several countries on the fringes of the former Soviet Union created a reasonably friendly climate for new businesses and achieved corresponding economic success-including Estonia, Hungary, Latvia, Poland, Slovenia, and the Czech Republic (which may have done reasonably well despite, rather than because of, mass privatization). Poland offers a nice contrast to Russia. It was slow to privatize its major businesses or its banks. It succeeded economically because it quickly privatized small businesses, created a climate in which new businesses could thrive, and built strong capital markets regulation that largely preceded large-firm privatization. ${ }^{7}$

This article proceeds as follows. Part II surveys Russian privatization and the sometimes astonishing corruption that accompanied the privatization effort. Part III discusses the factors that affect how much self-dealing the controllers of privatized enterprises will engage in, the structural flaws in Russia's privatization efforts, and the often unhappy outcomes from privatization. Part IV addresses the counterfactual question of what might have happened with staged privatization and greater effort to build institutions to control self-dealing. Part V evaluates Czech mass privatization, to assess the extent to which Russia's experience was rooted in large-firm privatization without controls on self-dealing, and to what extent that experience reflects Russia's unique problems. Part VI offers some suggestions for future privatization efforts and future aid to Russia. Part VII concludes.

We seek to understand what went wrong with a plausible reform program, what reforms might have worked better, and what can be done now. We part company with critics of mass privatization who espouse implausible alternatives,

\footnotetext{
${ }^{7}$ For a case study that attributes Poland's economic success partly to strong capital markets regulation, see Simon Johnson \& Andrei Shleifer, Coase v. the Coasians (working paper 1999), available in Social Science Research Network at 〈http://papers.ssrn.com/abstract_id=193776〉.
} 
such as Asian-style industrial policy (which Russia was incapable of carrying out), or seem mostly interested in assigning blame. ${ }^{8}$

\section{ACYNIC'S TOUR OF RUSSIAN PRIVATIZATION}

This Part surveys Russia's privatization history. Some of the stories that we report are well-known; others are newly reported here. Taken together, they paint a grim picture of a government that privatized small, mid-sized, and many large companies in semi-honest fashion through mass privatization, but tolerated virtual giveaways of majority stakes in the largest companies, where most of the value lay, as well as insiders' theft of the value of minority shares in most large companies.

A warning. The misdeeds that we report don't lend themselves to easy fact-checking. For some, we have personal knowledge; this is indicated in footnotes. For the others, we rely on news stories and sometimes, even less satisfactorily, on "general knowledge"-for example, the general belief that Gazprom CEO Rem Vyakhirev owns a substantial percentage of Gazprom's shares. Thus, we may inadvertently tell a story that isn't true or, more likely, provides a partial picture. Still, we believe that our overall depiction of Russian business practices is accurate. The problem in recounting misdeeds by Russian insiders isn't finding true stories, but picking among the juicy stories that abound.

\section{A. Mass Privatization: 1992-1994}

Russia in 1992 was a huge country with a weak central government, that had neither will nor capacity to force privatization onto unwilling company managers. The prevailing Western advice called for "shock therapy"-rapid decontrol of prices, freeing of markets, and privatization of industry. Speed was thought critical, both to revive the economy and to reduce the state's role in the economy before popular tolerance for the dislocations that accompanied the shock was exhausted and reform lost its political momentum. As shock therapist Jeffrey Sachs wrote:

The need to accelerate privatization is the paramount economic policy issue facing Eastern Europe. If there is no breakthrough in the privatization of large

\footnotetext{
8 For an industrial policy proposal, see Alice H. AmSden, JaceK Kochanowicz \& Lance TAYlor, The MARKet MeEts Its MATCh: Restructuring the ECONOMIES OF EASTERN Europe (1994). For a blaming effort, see ANINE R. WEDEl, Collision AND Collusion: The StRANGe CASE OF WeStern AID to EASTERn EuRoPe, 1989-1998 (1998).
} 
enterprises in the near future, the entire process could be stalled for years to come. Privatization is urgent and politically vulnerable. ${ }^{9}$

Privatization of state-owned enterprises in developed countries and some transition countries has proceeded primarily through one-company-at-a-time auctions, generally with reasonable transparency. ${ }^{10}$ But countries attempting the transition from centrally-planned to market economies had thousands of state-owned enterprises to dispose of, many of modest size, only some of which were viable. One-at-a-time cash auctions couldn't meet the shock therapists' timetable, and involved large transaction costs relative to enterprise value. Mass cash auctions were thought likely to exhaust the citizenry's funds and to risk political backlash if companies were sold to wealthy crooks, ex-government officials, or foreigners. ${ }^{11}$

Mass privatization became the favored alternative. Citizens would be given vouchers, which they could use to buy shares of privatized companies. The Czech Republic showed the way. Czech voucher privatization began in 1991, was well underway in 1992 when Russia started down the same road, and was largely complete by 1994 . Czech industry was in private hands, and a new investment fund industry had sprung up to collect vouchers from citizens and invest in privatized firms. These "voucher investment funds" promised diversification, plus strong outside owners who could replace managers who

\footnotetext{
9 Jeffrey Sachs, Accelerating Privatization in Eastern Europe: The Case of Poland, 1 NEw EuR. L. ReV. 71, 71 (1992); see also JefFrey SACHS, Poland's Jump to the MARKet ECONOMY (1993). For other statements of the prevailing Western wisdom, see ANDERS AsLund, How Russia Became a MARKet Economy (1995); Joseph R. Blasi, Maya Kroumova \& Douglas Kruse, Kremlin Capitalism: Privatizing the Russian Economy (1997); BOYCKO, SHLEIFER \& VISHNY (1995), supra note 1. For an argument that Poland's economic success came from building on existing institutions, not the shock of discarding them, see CRZEGORZ W. Kolodko, From Shock to Therapy: The Political Economy of Postsocialist TRANSFORMATION (2000).

10 See, e.g., Steven L. Jones, William L. Megginson, Robert C. Nash \& Jeffry M. Netter, Share Issue Privatizations as Financial Means to Political and Economic Ends, 53 J. FIN. Econ. 217 (1999).

${ }^{11}$ See Boycko, Shleifer \& Vishny (1995), supra note 3, at 71-72; Maxim Boycko, Andrei Shleifer \& Robert W. Vishny, Voucher Privatization, 35 J. Fin. ECON. 249 (1994). In hindsight, some of the arguments against mass cash auctions seem thin. Foreign participation in cash auctions could have been limited, as it was for voucher auctions. Ill-gotten wealth could be used to buy vouchers (Russian vouchers were tradeable) as easily as to buy companies in cash auctions. And Russians were not that poor. They had over $\$ 100$ billion in the state savings bank, at least before the government froze savings accounts and then destroyed their value through inflation.
} 
couldn't make the transition to a market economy. And the wealth giveaway from voucher auctions made them initially popular. ${ }^{12}$

Russia followed in the Czech Republic's footsteps, with some important differences. In the Czech Republic, most of a company's shares were distributed in voucher auctions; only a limited number of shares were reserved for managers and employees. A small number of voucher investment funds accumulated most of the vouchers and bought large stakes in most major firms. This gave most Czech firms major outside owners.

In Russia, there was neither political will nor administrative capacity to force privatization on unwilling managers. The political solution was to bribe them with cheap shares so they would pursue privatization voluntarily. Employees were also given large numbers of cheap shares, in a political bow to the Communist ideology of worker ownership of the means of production. The result: most privatized firms were initially majority owned by workers and managers. A typical outcome was 60-65\% manager and employee ownership, perhaps $20 \%$ ownership by individuals and voucher investment funds, with 15 $20 \%$ still held by the state, which planned to sell its remaining shares for cash in the future. Given Russian workers' passivity and ignorance of free markets, this ownership structure led to manager control of most enterprises.

Russian managers' personal stake in their companies was often modest to begin with, but rose quickly. In Russia, vouchers were tradeable. This let managers buy vouchers that they could trade for shares in their own companies. Managers often got the funds to buy vouchers by illegally "privatizing" company funds. They continued to accumulate shares after the voucher auctions were completed, by convincing or coercing employees to sell their shares cheaply. ${ }^{13}$

Some auctions were marked by other irregularities. Under the auction design, if fewer vouchers were bid for a company's shares, more shares would be distributed per voucher. This gave insiders an incentive to discourage others from bidding. There were various ways to achieve this result. The auction location could be hard to reach (Russia is a large country with limited transportation), or could be announced or changed at the last minute. In some cases, phone calls and air flights into the city where the auction took place were conveniently disrupted shortly before the auction, or armed guards excluded

\footnotetext{
12 We discuss the Czech Republic's experience with mass privatization in Part V infra. Our discussion of Russian privatization relies primarily on BLASI, KROUMOVA \& KRUSE (1997), supra note 9: Boycko, SHLEIFER \& VISHNY (1995), supra note 1; and the personal knowledge of Black and Tarassova.

13 See Blasi, Kroumova \& KrUSE (1997), supra note 9, at 193 (management ownership rose, on average, from $7 \%$ in 1994 to $10 \%$ in 1996, with the general director's stake rising from $2 \%$ to $4.5 \%$ ).
} 
unwanted bidders from the auction. The more valuable the company, the more likely its managers (or well-connected outside investors) were to use tactics like these. And perhaps 1000 of the 15,000 mass-privatized firms cut special deals with the government.

Finally, the largest enterpris es were held out of voucher privatization, with the government distributing at most a minority stake. In several important industries, the government created pyramid structures, bundling controlling stakes in a number of operating companies into a few holding companies and later sold controlling stakes in the holding companies. The government created seven oil holding companies: LUKOil, Sidanko, Sibneft, Rosneft, Tyumen Oil, Yukos, and VNK. Electric power (with United Energy Systems as the principal holding company) and telecoms (with Svyazinvest as the principal holding company) followed a similar pattern.

Pyramid structures everywhere are an invitation for controlling shareholders to siphon wealth from companies that they control, but have a limited economic stake in. ${ }^{14}$ This risk is imperfectly controlled in other countries because the pyramid commonly begins as a wholly-owned corporate group. The controlling family must develop a reputation for honesty, or no one will buy the noncontrolling shares that it wants to sell. The risk from pyramid structures was magnified in Russia by weak enforcement, plus controllers' ability to acquire control of a pyramid without first developing a reputation for honesty.

The privatizers knew that the auctions wouldn't be perfectly clean, and that manager/worker control of privatized companies would limit shareholder oversight of managers. They saw this as an acceptable political price to pay for rapid privatization. Even bad private owners were far better than state ownership. As Andrei Shleifer, a principal Western advisor to the Russian privatizers, and Dmitri Vasiliev, a top Russian privatizer, explained:

[Russian ownership] structures have been to a large extent determined by the political imperative of accommodating managerial preferences in the privatization program, since without manager support firms would have remained under political control. We believe that the ownership structures emerging from Russian privatization, while farsuperior to state ownership, still

${ }^{14}$ See Lucian Bebchuk, Reinier Kraakman \& George Triantis, Stock Pyramids, Cross-Ownership, and Dual Class Equity: The Creation and Agency Costs of Separating Control from Cash Flow Rights (Olin Ctr. for Law, Econ., and Bus., Harvard Law Sch., Working Paper No. 249, 1998), available in Social Science Research Network at <http://papers.ssrn.com/paper.taf?abstract_id=147590〉. 
give managers too much control relative to what is needed to speed up efficient restructuring .... ${ }^{15}$

The privatizers ignored the special risks created by pyramid structures. We recall no discussion of this issue at the time, and it isn't mentioned in contemporaneous literature.

For our part, we don't doubt that privatization gave managers incentives to make profits. The harder question, to which we return in Part III, was how many managers would seek to profit by improving their business, versus how many would steal the value that the business still had.

\section{B. "Loans-for-Shares" and Other Rigged Auctions: 1995-Present}

A story. The U.S. Government owes $\$ 25$ billion to Germany. To pay off the obligation, it gives $\$ 25$ billion to Bank of America with instructions to wire the funds to the German government. The money never arrives. No one ever finds out where it went, or really tries to find out. No one at Bank of America goes to jail. The government never asks Bank of America to pay the money back, and the government continues to do business with Bank of America. Indeed, the President invites Bank of America's CEO to become a cabinet secretary, in charge of economic reform. For a time he agrees, before deciding that there is more profit to be made by dealing with the government than by helping to run it.

This story isn't remotely possible in the United States. But change the bank to Oneksimbank (owned by kleptocrat Vladimir Potanin), run the money not through Oneksimbank itself but through two affiliated banks, and reduce the amount to $\$ 502$ million, which is a rough Russian equivalent of $\$ 25$ billion as a proportion of GNP, and it becomes a true Russian story, less widely known than it ought to be. ${ }^{16}$ It's no longer hard to understand how Oneksimbank accumulated enough money to become a principal proponent and beneficiary of the rigged "loans-for-shares" auctions of major companies, through which

\footnotetext{
15 Andrei Shleifer \& Dmitry Vasiliev, Management Ownership and Russian Privatization, in 2 Corporate Governance in CEntral Europe And Russia: Insiders AND the State 62 , 76-77 (Roman Frydman, Cheryl W. Gray \& Andrzej Rapaczynski eds., 1996); see also Nellis (1999), supra note 2, at 18 (For the IMF and the World Bank, "[t]he immediate need was to create a basic constituency of property owners: to build capitalism, one needed capitalists- lots of them, and fast.").

16 See Matt Bivens \& Jonas Bernstein, The Russia You Never Met (informally circulated English version; Russian version was published in DEMOKRATIZATZIYA (1999)) (on file with authors, available without footnotes at <//http://www.wayan.net/journal/russia/feb_22.htm>); Russian Finance: Byzantium, Inc., ECONOMIST, July 19, 1997, at 62.
} 
Russia sold its largest companies for a small fraction of fair value, beginning in 1995. The same deep corruption that let Potanin walk off with half-a-billion dollars can explain why the Russian government tolerated the obvious rigging of the loans-for-shares auctions, even though it was desperate for the revenue that honest auctions might have produced. ${ }^{17}$

Another popular way to instant wealth: Arrange to manage government funds, which involved paying little or no interest to the government while reinvesting the funds at market rates during a high-inflation period when interest rates were in triple or high-double digits. Vladimir Gusinski's MOST Bank got its start managing money in this manner for the Moscow city government; Potanin's Oneksimbank managed money for the Finance Ministry and the Foreign Trade Ministry; Mikhail Fridman's's Alfa Bank managed funds for the Customs Service and distributed agricultural subsidies. Khodorkovski's Bank Menatep handled the funds that Russia spent on its 1996 military operations in Chechnya and later promised to spend on rebuilding Chechnya. A Russian government audit later estimated that some $\$ 4.4$ billion of these funds never arrived at their intended destination. ${ }^{18}$ As Pyotr Aven, then head of Alfa Bank (controlled by kleptocrat Mikhail Fridman), candidly explained:

To become a millionaire in our country it is not at all necessary to have a good head and specialized knowledge. Often it is enough to have active support in the government, the parliament, local power structures and law enforcement agencies. One fine day your insignificant bank is authorized, for instance, to conduct operations with budgetary funds. Or quotas are generously allotted ... for the export of oil, timber, and gas. In other words, you are appointed a millionaire ... ${ }^{19}$

17 For a more recent example, see Funds Sent to Kemerovo Missing? RADIO FreE Europe/RAdio Liberty Newsline, May 21, 1999 <http://www.rferl.org/newsline/1999/05/1rus/rus-210599.html> ( $\$ 100$ million foreign loan, intended for the coal industry in Kemerovo Oblast, never arrived at its destination) (<http://www.rferl.org/newsline/1999/05/210599.htm〉). On general Kremlin corruption, see Celestine Bohlen, Russian Says He Has Proof Bribes Were Paid to Kremlin, N.Y. Times, Aug. 31, 1999, at A8; Celestine Bohlen \& Michael R. Gordon, Lawmakers Turn Back Another Attempt by Yeltsin to Dismiss His Chief Prosecutor, N.Y. TIMES, Oct. 14, 1999, at A6; Geoffrey York, Kremlin Kills Corruption Probe of Highly Placed Officials, Globe \& MAIL (TORONTO), June 26, 1999, at A16.

18 On Gusinski and Potanin, see Bivens \& Bernstein (1999), supra note 16. On Fridman, see Craig Mellow, The Oligarch Who Knew Better, INST. InveStor, June 1999, at 95 . On Khodorkovski, see The Abuses of "Authorized Banking," RADio FreE Europe/RAdio Liberty (Jan. 1998) <http://www.rferl.org/nca/special/rufinance/authorize.html>.

19 Igor Baranovsky, Terror is a Fact of Russian Competition, Moscow News, July 22, 1994, at 22 (quoting Mr. Aven). 
Loans-for-shares was an audacious scheme to leverage wealth acquired in these dubious ways, by using it to acquire Russia's biggest companies for a small fraction of their value. ${ }^{20}$ It began in 1995 with a proposal by Potanin, backed by most of the major new Russian banks. The Russian Government wanted to raise revenue but found it politically hard to sell its stakes in these enterprises, which had been excluded from voucher privatization. The banks proposed to loan funds to the government for several years, with repayment secured by the government's controlling stakes in these enterprises. Everyone understood that the Government would not repay the loans, and would instead forfeit its shares to the banks that made the loans.

Under loans-for-shares, the Government auctioned its shares in a number of major oil, metals, and telephone companies, with accompanying voting rights, as security for loans, giving the shares to whomever would loan it the most money. But the auctions were peculiar indeed. The right to manage the auctions was parceled out among the major banks, who contrived to win the auctions that they managed at astonishingly low prices. The bid rigging that was implicit in divvying up the auction-managing role became explicit in the actual bidding. The auction manager participated in two separate consortia (to meet the formal requirement for at least two bids), each of whom bid the government's reservation price or trivially above that. No one else bid at all. Foreigners were either excluded formally or understood that it was pointless to try to bid.

In the couple of cases when someone bid for a company intended to be won by someone else, pretexts were found to disqualify the high bidder. For example, Oneksimbank managed the Norilsk Nickel auction, with a reservation price of $\$ 170$ million. It arranged three bids from affiliates, all at $\$ 170$ or $\$ 170.1$ million. Unexpectedly, Rossiiski Kredit Bank offered \$355 million, over twice as much. Oneksimbank disqualified Rossiiski Kredit's bid on the grounds that the bid amount exceeded Rossiiski Kredit's charter capital (the nominal value of its outstanding shares); Oneksimbank's affiliate won the bidding at $\$ 170.1$ million. No matter that Oneksimbank's winning bid suffered from the same defect, nor that Rossiiski Kredit's charter capital didn't affect its ability to pay the bid amount, nor that the auction rules required Oneksimbank to provide any objections in advance of the auction, to give bidders time to cure them. Not that either bid reflected the value of Norilsk Nickel, which had annual profits of around $\$ 400$ million.

\footnotetext{
${ }^{20}$ Our discussion of the loans-for-shares auctions relies primarily on Ira W. Lieberman \& Rogi Veimetra, The Rush for State Shares in the "Klondyke" of Wild East Capitalism: Loans-for-Shares Transactions in Russia, 29 GEO. WASH. J. INT'L L. \& ECON. 737 (1996), and the personal knowledge of Black and Tarassova.
} 
The loans-for-shares auctions were auctions that the world was watching. Hopes that visibility, plus the government's desperate need for revenue, would instill some semblance of honesty, were disappointed. Meanwhile, auctions that the world wasn't watching were often even worse. For example, Russian formed Zarubezhtsvetmet (in Russian, this means "foreign nonferrous metals") to hold its $49 \%$ stake in a joint venture with the Mongolian government, which ran Mongolia's Erdenet copper mine. Zarubezhtsvetmet's market value was perhaps $\$ 250$ million. It was sold for $\$ 150,000$ to insiders with connections to the Russian Metallurgy Ministry. No matter that Mongolia had the right to approve any transfer of Russia's interest in Erdenet, and a right of first refusal to buy Russia's stake at the price at which it was offered to someone else. That right was ignored, despite Mongolia's official government complaint. ${ }^{21}$

Rather more of a nuisance was the Russian prosecutor who sued in 1997 to reverse the privatization of Zarubezhtsvetmet, on the grounds that Mongolia hadn't consented to Russia's transfer of its interest in Erdenet. ${ }^{22}$ The prosecutor's error was soon corrected, and the suit has proceeded no further. A second official complaint by Mongolia in 1998 received a blunt response:

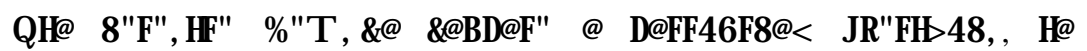

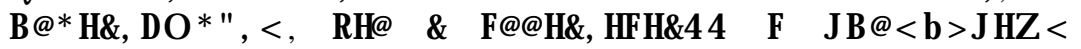
$<, 0$ BD' $\& A H: \backslash F H \&>>Z<E \propto:$ :T, $>4,<4<$ b\& b, $\mathrm{Fb}$ @BDZH@ "8P4@, D@@ @V , FH@ “\%, T >, 8@@4R, F8@ @ $\mathrm{X}, * 4>,>4$,

$1 " \mathrm{D} \$, 0 P \& H, H$. [With regard to your question about the Russian participant [in Erdenet], this is to verify that in accordance with the [RussianMongolian agreement on creation of Erdenet], it is Zarubezhtsvetmet. $]^{23}$

The fix was still in.

${ }^{21}$ Our discussion of Erdenet and Zarubezhtsvetmet is based on conversations between1996 and 1998 between Bernard Black and Z. Enkhbold, Head of the State Property Committee of Mongolia, and on the Erdenet joint venture agreement, $\mathrm{E} \propto$ : "T, $>4,<, 0 * \mathrm{~J}$ BD'\&4H: \FH\&@<

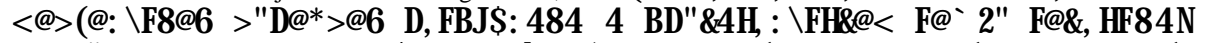

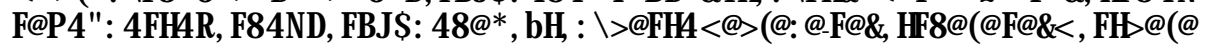

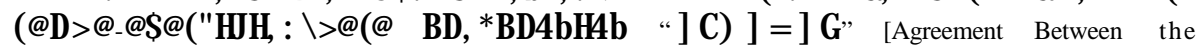
Government of the Mongolian Peoples' Republic and the Government of the Union of Soviet Socialist Republics on the Activity of the Mongol-Soviet Joint Mining-Concentrating Enterprise "ERDENET"] (June 5, 1991) (on file with authors).

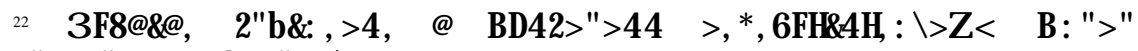

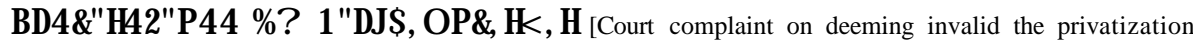
plan for VO Zarubezhtsvetmet], filed by the General Prosecutor in the Moscow Arbitration Court (May 6, 1997) (on file with authors).

${ }^{23}$ Letter from Yuri Maslyukov, First Deputy Prime Minister of the Russian Federation, to Prime Minister Elbegdorj of Mongolia (Oct. 29, 1998) (on file with authors). 
Another common tactic: Beginning in 1994, the government of ten required bidders in privatization auctions to promise specified future investments in the enterprise. ${ }^{24}$ Once the winning bidder acquired the shares, the promised investments were often quietly shelved, or the shares were transferred to supposedly good faith purchasers, who weren't bound by the investment promise. An honest purchaser couldn't use these dodges, so dishonest purchasers tended to win the auctions.

Another privatization rule gave a firm's managers the right to acquire $30 \%$ of its shares cheaply if they first secured an agreement with the employees that would prevent the enterprise from going bankrupt for one year. Since proof that the enterprise would go bankrupt without the agreement, or wouldn't go bankrupt for a year with it, was in the eye of the beholder, this was an all-butopen gift of a controlling stake to the managers, in return for a phony agreement with the employees. ${ }^{25}$

The rigged auctions still continue. For example, in late 1999, an unknown offshore company, presumably controlled by LUKOil's managers, bought $9 \%$ of its shares from the government for $\$ 3$ per share when the market price was $\$ 8$, marking the third time in five years that LUKOil management had bought a block of LUKOil shares from the government for less than the market price. ${ }^{26}$

\section{The Outcome: A Kleptocracy}

Taken as a whole, Russian privatization led to several distinct outcomes. First, a kleptocracy emerged. A small number of individuals, who mostly achieved initial wealth through favorable deals with or outright theft from the government, ended up controlling most of Russia's major firms and, to a nontrivial extent, the government itself. Second, as we discuss in Part IV, mass privatization hasn't measurably improved firm productivity.

Third, the Russian public came to associate privatization with corruption, increased crime, and fabulous wealth for a chosen few while workers and pensioners go unpaid. By 1992, Russia had a new slang term for privatization

\footnotetext{
${ }^{24}$ See Basic Provisions of the State Programme of Privatization of State-Owned and Municipal Enterprises in the Russian Federation after July 1, 1994 § 3.4.2, approved by Decree of the President of the Russian Federation No. 1535 of July 22, 1994 (LEXIS, Intlaw Library, RFlaw File).

${ }^{25}$ See Regulations for the Procedure of Concluding an Agreement for Acquiring Shares with the Group of an Enterprise's Workers Who Have Undertaken to Implement the Privatization Plan and to Prevent the Bankruptcy of the Enterprise to be Privatized, approved by Order of the State Committee for State Property Management of the Russian Federation No. 862-R of Nov. 23, 1992 (LEXIS, Intlaw Library, RFlaw File).

${ }^{26}$ See Matt Bivens, Cyprus Company Buys LUKOil Share, Moscow Times, Oct. 30, 1999.
} 
that combined the word for privatization (Russian: BD4\&'HA2'P4b (privatizatziya)) with the verb BDANQ'HAH (to grab, to take improperly) to form BD4N\&"'H2"P4b (prikhvatizatziya), roughly translated as "grabprivatization." Top privatizer Anatoli Chubais was known as the (: " $\$ Z \mathbf{Z 6}$ BD4N\&' HA2" HCD (glavni prikhvatizator; the chief grab-privatizer). Popular disgust with privatization strengthened the Communists and other anti-reform political parties. ${ }^{27}$

As the kleptocrats' power grew, many bought TV stations, newspapers, and other media outlets to promote the election of friendly politicians and blunt public criticism of their activities. They now control most major Russian newspapers and TV stations. To follow a political debate in the Russian press, or a turf battle within the government, one must understand which kleptocrat owns which newspaper, and which kleptocrat is allied with which politician. ${ }^{28}$

Table I lists those most often named as among the kleptocrats, and their principal investments, government connections, and media outlets. Other recent or current major players include Roman Abramovich (Berezovski's apparent partner; Chairman of Sibneft); Vladimir Bogdanov (Surgutneftegaz); the Chernoy brothers (aluminum companies); Anatoli Chubais (former Prime Minister; head of the UES electric power company); and Vladimir Vinogradov (Inkombank). ${ }^{29}$

27 Stiglitz (1999), supra note 2, also notes the chilling effect that dirty privatization had on other market reforms. On the possibility that a rule, although efficient in the near term, may be inefficient in the long run because it produces political backlash, see Mark J. Roe, Backlash, 98 Colum. L. Rev. 217 (1998).

${ }^{28}$ See, e.g., Laura Belin, A Year of Discord, in AnNual Survey of EASTERn EuRope AND THE Former Soviet Union: 1997-The Challenge of Integration, at 276 (Peter Rutland ed. 1998); Laura Belin, Changes in Editorial Policy and Ownership at Izvestiya, in id. at 291; Floriana Fossato \& Anna Kachkaeva, Russian Media Empires III, RADIO FreE EuRoPE/RAdio LIBERTY (May 26, 1998) <http://www.rferl.org/nca/special/rumedia3/index.html>.

${ }^{29}$ Sources for Table I include many of the articles cited above, personal knowledge, a chart made public by the U.S. State Department section on Intelligence and Review, Russia's Business Magnates: Their Empires and Interrelationships (July 1998), Juliet Johnson, Russia's EmergingFinancialIndustrial Groups, 13 POST-Soviet AFr. 333 (1997), Donald N. Jensen, Russia's Financial Empires, R A D I O FRE E E U R P E / R A D I O L I b E R T ( J a n . 1998 ) <http://www.rferl.org/nca/special/rufinance/index.html>, and Kirsten Vance, FIGs Rx Figures, RussIA REV., July 31, 1998, at 24. We used our best judgment in resolving conflicts between sources about who owns what. On the LUKOil-Luzhkov connection, see "Party of Exporters" to be Victor in Upcoming Parliamentary Elections, RUSis J., May 24-30, 1999, <http://www.russiajournal.com/start/opinion/article_17_450.htm>. On Gazprom, Chernomyrdin, and Vyakhirev, see, e.g., Aleksandras Budrys, Ex-Russia PM Chernomyrdin returns to Gazprom, REUTERS, June 30,1999; Gazprom and Regions Cozy Up, RussiA J., May 24-30, 1999, <http://www.russiajournal.com/start/business/article_17_466.htm>; John Lloyd, The Russian Devolution, N.Y. TIMES, Aug. 15, 1999, $§ 6$ (Magazine), at 34, 51 (discussing Chernomyrdin's 
Table I

Russia's Kleptocrats and their Principal Holdings

\begin{tabular}{|c|c|c|}
\hline $\begin{array}{l}\text { Kleptocrat (known } \\
\text { political } \\
\text { connections) }\end{array}$ & Principal Companies & Media Outlets \\
\hline $\begin{array}{l}\text { Vagit Alekperov } \\
\text { (ties to Moscow } \\
\text { Mayor Yuri } \\
\text { Luzhkov) }\end{array}$ & $\begin{array}{l}\text { LUKOil (largest Russian oil } \\
\text { company); Bank Imperial (with } \\
\text { Vyakhirev) }\end{array}$ & $\begin{array}{l}\text { Izvestia newspaper (with } \\
\text { Potanin); TV-6 (with } \\
\text { Berezovski) }\end{array}$ \\
\hline $\begin{array}{l}\text { Boris Berezovski } \\
\text { (ties to the family of } \\
\text { former President } \\
\text { Boris Yeltsin; former } \\
\text { Prime Minister } \\
\text { Viktor } \\
\text { Chernomyrdin; } \\
\text { Kremlin chief of } \\
\text { staff Alexander } \\
\text { Voloshin) }\end{array}$ & $\begin{array}{l}\text { Sibneft (oil and gas holding } \\
\text { company), LogoVAZ (auto } \\
\text { distributor), Aeroflot and } \\
\text { Transaero airlines, } \\
\text { Avtovazbank; Obyedinenni } \\
\text { Bank }\end{array}$ & $\begin{array}{l}\text { ORT (with Fridman), TV6 (with } \\
\text { Alekperov), and STS } \\
\text { television stations; Vremya } \\
\text { television program; NSN } \\
\text { radio, Nezavisimaya gazeta, } \\
\text { Novaya izvestya and } \\
\text { Kommersant newspapers, } \\
\text { Ogonek magazine }\end{array}$ \\
\hline $\begin{array}{l}\text { Viktor } \\
\text { Chernomyrdin } \\
\text { (former Prime } \\
\text { Minister) }\end{array}$ & \multicolumn{2}{|c|}{$\begin{array}{l}\text { Gazprom (natural gas) (chairman; reputed share ownership) } \\
\text { (Gazprom's ownership of other companies is listed below for } \\
\text { Vyakhirev) }\end{array}$} \\
\hline $\begin{array}{l}\text { Mikhail Fridman } \\
\text { (ties to Kremlin } \\
\text { chief of staff } \\
\text { Alexander Voloshin) }\end{array}$ & $\begin{array}{l}\text { Alfa Group holding company, } \\
\text { Alfa Bank, Tyumen Oil (oil } \\
\text { holding company), Alfa } \\
\text { Cement, various real estate, } \\
\text { construction and oil export } \\
\text { companies }\end{array}$ & $\begin{array}{l}\text { Alfa TV, ORT television } \\
\text { station (with Berezovski) }\end{array}$ \\
\hline
\end{tabular}

reputed ownership of Gazprom shares). There may be an ongoing power struggle between Chernomyrdin (appointed as Gazprom's Chairman in 1999) and Vyakhirev (Chief Executive Officer) for control of Gazprom. On Berezovski's media interests, see Get Gusinsky, ECONOMIST, Nov. 20, 1999, at 58; Andrew Higgins, Russian Newspaper Finds Itself in a Tug of War Over Ownership, WALL ST. J., Aug. 9, 1999, at A15. On Luzhkov, see Paul Klebnikov, Who Will be the Next Ruler of Russia? The Slick City Boss or the Rough-Edged Populist General, ForBES, Nov. 16, 1998, at 152; Mark Whitehouse, Moscow Mayor Steals Political Spotlight, WALl St. J., May 20, 1999, at A14. 


\begin{tabular}{|c|c|c|}
\hline $\begin{array}{l}\text { Kleptocrat (known } \\
\text { political } \\
\text { connections) }\end{array}$ & Principal Companies & Media Outlets \\
\hline $\begin{array}{l}\text { Vladimir Gusinski } \\
\text { (ties to Moscow } \\
\text { Mayor Yuri } \\
\text { Luzhkov) }\end{array}$ & $\begin{array}{l}\text { Media Most holding company, } \\
\text { Most Bank }\end{array}$ & $\begin{array}{l}\text { Sevodnya, Novaya gazeta } \\
\text { (with Smolenski), Obshchaya } \\
\text { gazeta, } 7 \text { dnei and Smena } \\
\text { newspapers; Ekho Moskvuoy } \\
\text { radio; NTV and NTV+ (with } \\
\text { Vyakhirev), and TNT } \\
\text { television stations, Itogi and } \\
\text { Lisa magazines }\end{array}$ \\
\hline $\begin{array}{l}\text { Mikhail } \\
\text { Khodorkovski (ties } \\
\text { to former Prime } \\
\text { Minister Yevgeni } \\
\text { Primakov; former } \\
\text { Fuel and Energy } \\
\text { Ministry head } \\
\text { Sergei Generalov) }\end{array}$ & $\begin{array}{l}\text { Rosprom (holding company), } \\
\text { Bank Menatep, Yukos and } \\
\text { VNK oil and gas holding } \\
\text { companies, various } \\
\text { manufacturing, copper, } \\
\text { chemical, timber, and retail } \\
\text { companies }\end{array}$ & $\begin{array}{l}\text { Moscow Times, St. Petersburg } \\
\text { Times, and Literaturnaya } \\
\text { gazeta newspapers }\end{array}$ \\
\hline $\begin{array}{l}\text { Yuri Luzhkov } \\
\text { (Moscow Mayor) }\end{array}$ & $\begin{array}{l}\text { through City of Moscow: Guta } \\
\text { Bank, Bank Moskvuoy, Bank } \\
\text { for Reconstruction and } \\
\text { Development, reputed to take a } \\
\text { piece of every significant real } \\
\text { estate deal in Moscow }\end{array}$ & $\begin{array}{l}\text { Moskovski komsomolets } \\
\text { newspaper; TV Center (TV } \\
\text { station owned by City of } \\
\text { Moscow) }\end{array}$ \\
\hline $\begin{array}{l}\text { Vladimir Potanin } \\
\text { (former Deputy } \\
\text { Prime Minister, ties } \\
\text { to former Deputy } \\
\text { Prime Minister } \\
\text { Anatoli Chubais) }\end{array}$ & $\begin{array}{l}\text { Interros holding company, } \\
\text { Oneksimbank, RosBank, MFK } \\
\text { Renaissance investment bank, } \\
\text { various insurance companies, } \\
\text { Norilski Nickel (nickel and other } \\
\text { nonferrous metals), Sidanko (oil } \\
\text { and gas holding company), } \\
\text { Novolipetsk (steel), 25\% of } \\
\text { Svyazinvest (telephone holding } \\
\text { company), Perm Motors } \\
\text { (aircraft), various metallurgical, } \\
\text { shipping and industrial } \\
\text { companies }\end{array}$ & $\begin{array}{l}\text { Izvestia (with Alekperov), } \\
\text { Komsomolskaya pravda (with } \\
\text { Vyakhirev) and Russki telegraf } \\
\text { newspapers, Ekspert magazine }\end{array}$ \\
\hline
\end{tabular}




\begin{tabular}{|l|l|l|}
\hline $\begin{array}{l}\text { Kleptocrat (known } \\
\text { political } \\
\text { connections) }\end{array}$ & Principal Companies & Media Outlets \\
\hline $\begin{array}{l}\text { Aleksander } \\
\text { Smolenski }\end{array}$ & $\begin{array}{l}\text { SBS-Agro Bank, Agromprom } \\
\text { Bank, possible co-owner with } \\
\text { Berezovski of Sibneft }\end{array}$ & $\begin{array}{l}\text { Novaya Gazeta (with Gusinski) } \\
\text { and National News Service } \\
\text { newspapers, Dengi magazine }\end{array}$ \\
\hline $\begin{array}{l}\text { Rem Vyakhirev (ties } \\
\text { to former Prime } \\
\text { Minister Viktor } \\
\text { Chernomyrdin) }\end{array}$ & $\begin{array}{l}\text { Gazprom (natural gas) (CEO, } \\
\text { reputed share ownership), Bank } \\
\text { Imperial (with Alekperov), } \\
\text { Inkombank (minority stake), } \\
\text { Gazprombank, National Reserve } \\
\text { Bank, Promstroibank, Komitek } \\
\text { oil company }\end{array}$ & $\begin{array}{l}\text { Komsomolskaya pravda (with } \\
\text { television stations (with } \\
\text { Gusinski); Rabochaya tribuna, } \\
\text { Trud, and Profil magazines, } \\
\text { various regional newspapers } \\
\text { and TV stations; minority } \\
\text { stake in Media Most (see } \\
\text { Gusinski) }\end{array}$ \\
\hline
\end{tabular}

\section{STRUCTURAL FLAWS IN RUSSIAN PRIVATIZATION}

Russian privatization was dirty. On the whole, the bigger the stakes, the dirtier the deal. Its advocates hoped that even if the manner of distributing the state's wealth was regrettable, the outcome would be salutary. New owners, motivated by profit, would improve the privatized companies' operations. The new owners would get rich, perhaps undeservedly, but the whole country would benefit from the productivity gains.

These hopes have not been fulfilled. This Part seeks to understand why. Sections A-D are the theoretical core of this article. They develop a framework for understanding why Russia's corporate owners and managers often chose self-dealing over company building, and apply that framework to the Russian environment. Sections $\mathrm{E}$ and $\mathrm{F}$ discuss the outcomes from voucher privatization and the kleptocrats' actions after they acquired control of Russia's biggest companies. Part IV turns to the counterfactual: what might have happened with slower privatization and greater efforts to build market-supporting institutions.

${ }^{30}$ Smolenski is often listed as one of the kleptocrats, but there is also evidence that he is partly or mostly a front man for Boris Berezovski, who rarely owns anything in his own name. Conversely, Berezovski's partner, Roman Abramovich, may be emerging as a first-tier kleptocrat in his own right. See Eduard Gismatullin, Sibneft Director Steps onto Kremlin Stage, Moscow Times, June 1, 1999 (describing Abramovich's and Berezovski's joint control of Sibneft and related companies). 


\section{A. The Controller's Dilemma: Build Value or Loot?}

Consider a stylized account of the dilemma facing a Russian manager or outside investor who acquires control of a privatized firm. The controller wishes to maximize his private return on investment. He is, we will assume, amoral, interested only in personal gain. In the short run, he has nearly absolute power over his firm's decisions and faces no restrictions on self-dealing. If the enterprise isn't viable, our amoral controller will steal what he can, leaving an empty shell behind. The more interesting case is when the firm is potentially profitable. How will the controller behave?

There are two basic ways for our hypothetical amoral controller to earn private returns. The first (the "value-creating" strategy) is to increase the firm's value, and thus the value of the controller's fractional stake in the firm. The second (the "self-dealing" strategy) is to expropriate value from other claimants. For example, by self-dealing enough to extract all of the firm's free cash flow, the controller can appropriate the payments that would otherwise go to the government as income taxes or to minority shareholders as dividends. By self-dealing beyond this point, the controller can skim revenues that would otherwise go to pay the firm's suppliers, employees, or creditors.

If the value creating and self-dealing strategies were independent, an amoral controller would maximize returns along each dimension independently. He would create as much value as possible and steal as much of that value as possible. The two strategies are not independent, however. A controller who skims revenues owed to suppliers and employees risks destroying the firm's going concern value. Suppliers and employees can't be defrauded indefinitely, even if they have no legal recourse. Sooner or later, they will stop doing business with the firm.

Even for self-dealing limited to a firm's free cash flow, there are tradeoffs between increasing value and self-dealing. For example, if the controller skims the firm's profits while continuing to pay its suppliers and employees, he expropriates the government's income tax revenues and the value of minority shares without jeopardizing the firm's survival. But the firm will be unable to obtain external financing to pursue new business opportunities or support major investments. Nor can the controller use internal financing for these purposes without revealing the firm's profitability to the tax authorities and minority investors. Moreover, it may be hard to skim tax payments without also stiffing suppliers and employees. A company that pays its suppliers and employees reveals that it can afford to pay some taxes (or bribes in lieu thereof), which the tax authorities will try to collect.

A controller also can't expropriate the value of minority shares and then sell the company at fair value to a new owner. The steps taken to expropriate the 
minority will conceal the firm's profitability. Potential buyers will discount heavily claims about true value by controllers who have proven themselves untrustworthy by expropriating minority shareholders. Finally, a controller may be skilled at self-dealing or creating value but not both.

For all these reasons, self-dealing will decrease a profitable firm's value. The controller can't independently maximize returns from creating value and self-dealing; he must maximize them jointly. With no enforcement, controllers are likely to pursue a mixed strategy. A controller who mostly maximizes value is likely to also extract some private returns. Conversely, a controller who mostly self-deals will likely keep a potentially viable firm alive. A firm that continues to operate can bring in new funds from suppliers, employees, creditors, and perhaps the government and shareholders, as long as it can find new contracting parties or pay the old ones just enough to keep their hopes of full payment alive. Moreover, keeping the firm alive lets the controller retain the option to sell the firm or build value in the future if business conditions improve.

The tension between creating value and looting increases as the risk of future sanctions grows. Consider the extreme case in which sanctions are certain, but won't be imposed for a while. Thieves who will be caught if they linger too long won't capture the firm's long-term value anyway. An amoral controller then has a sharp choice: create value (perhaps with self-dealing at a level that is unlikely to lead to sanctions), or steal as much as you can and then flee the jurisdiction before the police arrive.

In Russia, with enforcement uncertain, most controllers of viable enterprises would likely pursue a mixed strategy of enhancing firm value and grabbing the existing value. The critical question is: How much of each will they do?

In our view, three broad classes of factors shape controllers' choices. The first (Section B) is the legal and institutional infrastructure that affects the level of self-dealing that is feasible and the risk that self-dealing will lead to sanctions. The second (Section C) includes general regulatory and economic factors that affect all firms, especially the overall business climate. The third (Section D) includes factors associated with particular firms or controllers.

\section{B. Russia's Legal and Institutional Infrastructure}

Consider first the legal and institutional constraints on self-dealing. The Soviet Union wasn't a very honest place to begin with. At the same time, the scale of dishonesty was limited. Managers and workers in stores could appropriate and resell some of the best goods, but there were others whose job was to control this petty theft. Managers of state-owned firms couldn't set up 
transfer pricing schemes with other companies that the managers owned because citizens couldn't own companies. Bureaucratic controls kept managers away from direct access to the payments that a company received for its goods, and provided oversight of those who had access to money.

Besides, the money from large-scale corruption couldn't buy very much-a new Russian car or a nice vacation (but senior managers and government officials already had cars and government-provided vacations), but not a fancy house, a fat savings account (which would be noticed), or a foreign vacation or bank account (both generally not possible). And if you got caught being too greedy, you faced a lengthy term in a miserable Russian jail or gulag (work camp), which you certainly wouldn't enjoy and might not survive. Thus, we disagree with those who claim that Russia was so hopelessly corrupt at the start of the 1990s that little could be done to control managers' theft of company assets.

In the early 1990s, Russia wholly lacked the institutional infrastructure to control self-dealing. Prosecutors, judges, and lawyers had no experience in untangling corporate transactions or understanding of the indirect ways in which company insiders can siphon off profits. Concepts of fiduciary duty and proscriptions against self-dealing didn't exist. ${ }^{31}$ Russia had neither business lawyers who could advise managers on how to behave towards shareholders, nor accountants who could ensure accurate financial disclosure. Its accounting rules were designed to meet the needs of central planners, not investors. The Finance Ministry is gradually updating Russia's accounting rules, but often develops rules to determine how much tax a company owes rather than to help investors understand the company's cash flows. ${ }^{32}$

Basic commercial and capital markets laws didn't exist when voucher privatization was completed in 1994. The tax rules all but compelled managers to hide profits from tax inspectors and shareholders alike. A Securities Commission was created in 1994, but has a tiny budget, can't pay its staff

\footnotetext{
${ }^{31}$ In drafting the Russian Law on Joint Stock Companies, we had to adapt an existing word that didn't quite fit (2"4 H D, F@\&' $\gg$ Z6; zainteresovannuy) to refer to a person who has a conflict of interest for a transaction by a company. We were unable to employ the concept of fiduciary duty to behave in the company's interests rather than one's own interests, because we couldn't find an acceptable way to state this concept in Russian legal language.

${ }^{32}$ See Interview with Sergey Shatalov, First Deputy Minister of Finance, in No More Delays, in the Move to IAS, ACCT. REP., Jan./Feb. 2000, at 1 (Int'l Center for Acct. Reform, Moscow) (discussing Finance Ministry delays in moving to accounting rules based on International Accounting Standards; Shatalov explains that the IAS rules "do not specify in detail individual transactions . . . and the way to account for them for tax purposes").
} 
enough to keep qualified people, and lacks the political clout to investigate kleptocrat misdeeds.

Finally, the business culture was one of law avoidance. Under Communist rule, a good manager often had to obtain the parts and supplies needed to keep a factory running in unofficial ways. ${ }^{33}$ In a market economy, those skills were easily transferred to the new tasks of asset stripping and self-dealing.

The weak legal and institutional framework was no secret to the privatizers. But writing good laws can take years and building good institutions takes decades. The privatizers weren't willing to wait. They chose to privatize immediately, and hope that the laws and institutions would follow later. The laws did indeed follow. The first two Parts of a new Civil Code were adopted in 1995-96. A weak law on securities (since modestly strengthened) was adopted in 1995; a fairly strong law on joint stock companies in 1996; decent laws on bankruptcy and limited liability companies in 1998. These laws have weaknesses, but no more so than the laws in many other developing countries.

But the privatizers hoped for more than just decent laws. They hoped that broad private ownership would create a constituency for strengthening and enforcing those laws. That didn't happen. Instead, company managers and kleptocrats opposed efforts to strengthen or enforce the capital markets laws. They didn't want a strong Securities Commission or tighter rules on self-dealing transactions. And what they didn't want, they didn't get.

The tax rules are revised periodically, but haven't improved much. Why isn't clear. Perhaps their vagueness lets most businesses escape with a modest payment to the tax inspectors (and little to the government). The Finance Ministry and the tax inspectors mostly oppose reform, perhaps because clear rules and reasonable rates would reduce bribes. Perhaps too, company managers aren't too unhappy with the current system. They must hide their income, but can then steal the hidden profits. ${ }^{34}$

IMF intervention didn't help. A core IMF condition for new loans was higher tax revenues now. Lower tax rates and less administrative discretion wouldn't achieve that. In contrast, reforming the tax system was a soft condition that the IMF never insisted on. But Russia's drive to collect more tax revenue was counterproductive. Tax revenue as a percentage of GDP declined while corruption intensified, as businesses responded to higher tax demands with larger bribes.

\footnotetext{
33 See, e.g., Rozalina V. Ryvkina, What Kind of Capitalism Is Being Created in Russia?, RuSSIAN POL. \& L., May-June 1998, at 5, 21.

34 On the political economy of Russian tax reform, see ANDREI SHLEIFER \& DANIEL Treisman, Without a Map: Political Tactics AND ECONOMiC Reform In Russia (2000).
} 
The kleptocrats were able to co-opt the Central Bank and the Finance Ministry into opposing a strong securities law or Securities Commission. The Central Bank's bureaucrats were none too honest themselves, ${ }^{35}$ and didn't need much convincing that they, not the upstart Securities Commission, ought to control Russia's capital markets. As a result, the Securities Commission has limited powers and ended up in a protracted fight for political survival, which took most of what little resources it had.

The government's own behavior reinforced disrespect for rules. Managers had to cheat on their taxes, bribe tax and customs inspectors, and avoid cash transactions to survive. The government didn't pay its own bills to companies that provided it with goods and services, hardly an incentive for those companies to pay their tax bills. It became increasingly clear that corruption went right to the top—-to the extended Yeltsin "family."136

Company managers soon learned that they could plunder their firms with negligible risk of prosecution. For example, it's been almost two years since the 1998 ruble collapse exposed self-dealing at Russian banks and prompted a race to strip the assets that remained. Yet not a single bank official has been charged with anything. Khodorkovski's Bank Menatep offers an example of how the bankers behaved. After Bank Menatep collapsed in mid-1998, Khodorkovski transferred its good assets to a new bank, Menatep-St. Petersburg, leaving depositors and creditors to pick at the old bank's carcass. To ensure that the transactions couldn't later be traced, Khodorkovski arranged for a truck containing most of Bank Menatep's records for the last several years to be driven off a bridge into the Dybna river. Where presumably they will remain. ${ }^{37}$

Russia's core problem today is less lack of decent laws than lack of the infrastructure and political will to enforce them. ${ }^{38}$ For example, the company

${ }^{35}$ An example: the Central Bank's use of an obscure offshore firm to manage some of the Bank's foreign currency reserves, including keeping two sets of books to hide what it was doing. See Celestine Bohlen, Secrecy by Kremlin Financial Czars Raises Eyebrows, N.Y. Times, July 30, 1999, at $\mathrm{A} 8$.

${ }^{36}$ See, e.g., Michael Wines, Yeltsin Son-in-Law at Center of Rich Network of Influence, N.Y. TIMES, Oct. 7, 1999, at A1; sources cited in note 17 supra.

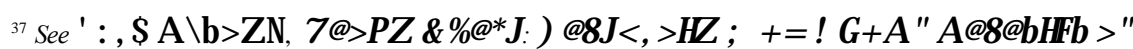
$*>$, ) J $\$>Z, 7 @<<, D^{\prime \prime} \nsucc$ [Gleb Pyannuyx, Endings in the Water: Menatep Documents Come to Rest at the Bottom of the Dybna, KommersanT], May 29, 1999, at 1.

38 See Katharina Pistor, Martin Raiser \& Stanislaw Gelfer, Law and Finance in Transition Economies (Eur. Bank for Reconstr. and Dev. Working Paper No. 48, 2000), available in Social Science Research Network at <http://papers.ssrn.com/paper.taf?abstract_id=214648> (reporting Russia's weakness on a variety of "rule of law" measures; finding a correlation between these measures 
law prohibits much of the rampant self-dealing by managers and large shareholders that occurs every day. But the courts respect only documentary evidence, which is rarely available given limited discovery and managers' skill in covering their tracks.

Moreover, a shareholder who sues a major company will usually lose at trial and first-level appeal, because of home-court bias, judicial corruption, or both. A shareholder with a strong case has a decent chance of getting an honest decision on further appeal, but that will take years. And judgments must be enforced (or, often, not enforced) by the same biased or corrupt lower court where the case began. ${ }^{39}$

A recent example: The bankruptcy proceedings for Sidanko, an oil holding company owned by kleptocrat Vladimir Potanin, and Chernogoneft and Kondpetroleum, two key Sidanko subsidiaries. Chernogoneft and Kondpetroleum went bankrupt after selling oil to Sidanko, which failed to pay for the oil and was itself looted so severely that it went bankrupt. In the Chernogoneft bankruptcy proceedings, $98 \%$ of the creditors voted for one external manager, but the local judge appointed a different manager with ties to Tyumen Oil, owned by kleptocrat Mikhail Fridman, which wanted to acquire Chernogoneft cheap. The court also rejected a Chernogoneft offer to pay all creditors in full! Tyumen was able to buy Chernogoneft for \$176 million and Kondpetroleum for $\$ 52$ million (a small fraction of actual value), in what Potanin publicly called "an atmosphere of unprecedented pressure on the court system." ${ }^{40}$ Which apparently means that Tyumen didn't merely bribe judges

and the strength of a country's capital markets).

39 For appraisals of Russian judicial corruption, see Jeffrey M. Hertzfeld, Russian Corporate Governance: The Foreign Direct Investor's Perspective, in Organization for Economic Co-operation and Development, Corporate Governance in Russia, at 6-7 (Conference Proceedings 1999) <http://www.oecd.org/daf/corporate-affairs/governance/roundtables/in-Russia/1999/index.htm> ("In many cases, the most likely explanation [for court decisions] is that improper influence has been exerted either through inducements or coercion. . . . [Among other problems], Russian courts have been regularly refusing to recognize and enforce international arbitration awards rendered against Russian parties."); Lee S. Wolosky, Putin's Plutocrat Problem, ForeIGN AFF., Mar./Apr. 2000, at 18, 27 ("In cases involving the oligarchs, trial and appellate judges are routinely bribed. Failing that, judges who evince a dangerous predisposition to impartiality are reassigned without explanation by superiors who are presumably on the take.").

${ }^{40}$ See Jeanne Whalen \& Bhushan Bahree, How Siberian Oil Field Turned into a Minefield, Wall St. J., Feb. 9, 2000, at A21, (quoting Potanin). Bernard Black was an advisor to a minority shareholder in Kondpetroleum in litigation against Sidanko and BP Amoco (a large Sidanko shareholder) for looting Kondpetroleum. For other pieces of the Chernogoneft bankruptcy story, see Igor Semenenko, Siberian Oil Company Fights Hostile Takeover, Moscow Times, May 29, 1999; Alan S. Cullison, Russia's Tyumen Oil Seeks to Expand with Some Assets of Troubled Sidanko, Wall St. J., July 8, 1999, at A12; Neela Banerjee, From Russia, With Bankruptcy, N.Y. TIMES, 
(Sidanko could have offered its own bribes), but threatened them as well. Indeed, a judge who issued an early ruling against Tyumen was beaten for his troubles. ${ }^{41}$

Sidanko's bankruptcy was marked by similar irregularities, some reflecting a battle between Potanin and Fridman for control of the proceedings. ${ }^{42}$ Other prominent bankruptcy cases were also rigged by insiders, with the cooperation of the courts and (for bankrupt banks) the Central Bank. ${ }^{43}$

Prosecutors are no better than judges. The reported price to stall a criminal investigation into, say, a business-related Mafia hit: \$50,000 in Moscow; less elsewhere. ${ }^{44}$

The privatizers, ourselves included, underestimated the extent to which functioning law requires honest courts and prosecutors that can redress gross violations. We called the Russian company law that we helped to draft a "selfenforcing" model because we thought that stating sensible rules would encourage corporate norms to coalesce around those rules (even with minimal enforcement), and that the courts could enforce simple procedural rules (for example, approval of self-dealing transactions by noninterested shareholders). ${ }^{45}$ Instead, self-dealing transactions were hidden, courts were of little help even when self-dealing was obvious, and managerial culture coalesced around concealing self-dealing instead of our intended norm of disclosure and a noninterested shareholder vote.

We've thought since about ways to strengthen the constraints on selfdealing. For example, requiring a company's accountants to report to shareholders on any self-dealing transactions they find and whether those transactions were completed in compliance with the company law would make it harder to conceal self-dealing. But our central view is that if enforcement is

Aug. 13, 1999, at C1.

${ }^{41}$ See Rules of War, ECONOMIST, Dec. 4, 1999, at 65 (Tyumen rival alleges that Tyumen intimidated local judges and complains that "If they just stuck to bribing judges, we could play that game too."); Wolosky (2000), supra note 39, at 30 (reporting the beating).

42 See, e.g., Gary Peach, Sidanko Squabbles Give Investment a Bad Name, Moscow TimES, June 1, 1999, at 14 (court rejects external manager proposed by 80\% of Sidanko's creditors).

43 See Olivier Blanchard, The Economics of Post-Communist Transition (1997).

${ }^{44}$ See Wolosky (2000), supra note 39, at 27.

45 See Black, Kraakman \& Tarassova (1998), supra note 1; Jonathan R. Hay \& Andrei Shleifer, Private Enforcement of Public Laws: A Theory of Legal Reform, 88 AMER. ECON. Rev. (Papers \& Proceedings) 398 (1998). 
weak enough, these and other possible changes to Russia's current not-so-bad rules won't matter much.

Having recounted Russia's many weak institutions, we should mention a problem that Russia didn't have in the early 1990s, at least in severe form. Theorists have speculated that social "trust"-the willingness of people to deal fairly with each other and expect others to do likewise-is an important marketsupporting institution. ${ }^{46}$ We have no sense that Russia was an especially lowtrust country at the beginning of the 1990s. Russians didn't trust their government, but enterprise managers routinely dealt with each other on an oral basis (often to circumvent formal regulations). Indeed, these informal contacts helped to make extensive barter chains a feasible substitute for cash-based transactions. One of the tragedies of Russian misgovernment in the 1990s is that Russia is a far more corrupt and lower-trust place today than a decade ago, with all that implies for its future prospects.

\section{Economy-Wide Factors}

A second broad class of factors that influence a controller's choice between value creation and self-dealing are economy-wide factors that affect a firm's potential profitability, and thus the opportunity cost from self-dealing instead of creating value.

\section{The Overall Business Climate}

A key factor is predicting the extent of looting is the overall business climate. The worse the business climate, the smaller the expected gains from creating value, and thus the more likely that controllers are to loot instead. Moreover, many state-owned enterprises will fail, and even viable enterprises will generally need to shed workers to improve productivity. New businesses must take up the employment slack. If they don't emerge, the market pressure

\footnotetext{
46 On trust and the related concept of social capital, see, e.g., FrANCIS FUKUYAMA, TRUST: The Social Virtues AND THE CReation of Prosperity (1995); Jonathan Temple \& Paul A. Johnson, Social Capability and Economic Growth, 113 Q.J. ECON. 965 (1998); Paul S. Adler \& Seok-Woo Kwon, Social Capital: The Good, the Bad, and the Ugly (working paper 1999), available in Social Science Research Network at <http://papers.ssrn.com/paper.taf?abstract_id=186928>; Luigi Guiso, Paola Sapienza \& Luigi Zingales, The Role of Social Capital in Financial Development (Ctr. for Research in Sec. Prices Working Paper No. 511, 2000), available in Social Science Research Network at <http://papers.ssrn.com/paper.taf?abstract_id=209610>. Russia doesn't appear on published multicountry rankings of trust or social capital, due to lack of data, so we can't use these rankings to verify or refute our intuition that Russia was a moderate-trust society in 1990.
} 
on large firms to restructure will be weaker; political pressure for firms to maintain employment and related social services will be stronger. ${ }^{47}$

Russia's business climate was lousy. We discuss the most important problems below, in rough order of importance.

a. Tax. Perhaps the single most important regulatory obstacle to earning an honest profit was the Russian tax system. Russian tax law is both amazingly complex and quite simple. The complex part is the vague and constantly changing rules and administrative interpretations. The nominal tax rates aren't extreme, but apply to a measure of "income" that grossly overstates actual income. Actual taxes can easily exceed $100 \%$ of profits. In addition, tax inspectors have broad discretion to seize a company's bank accounts and other assets to pay whatever taxes the inspector claims are due. Companies can appeal, but will be out of business long before the appeal is heard. Tax audits have become a potent political weapon, deployed by the government against businesses that don't support the incumbents. ${ }^{48}$

The simple part is how businesses behave: The confiscatory rates produce derisory revenues, because almost no one pays them. Instead, everyone hides income as best they can and bribes the tax inspectors to reduce whatever initial assessment the inspectors make. An important reason for Russia's development of an extensive barter economy is that cash in a bank account invites the tax inspectors to seize it. ${ }^{49}$

Falsified books preclude strong public capital markets. Companies that can't report income honestly to the tax inspectors also can't report honestly to investors. Investors therefore can't use a company's financial statements to check on management honesty and skill. They have to hope that the company is profitable and (usually in vain) that managers won't steal its hidden income. The frequent use of barter makes matters still worse. In a barter transaction

47 See Olivier Blanchard, The Economics of Post-Communist Transition (1997)

48 See, e.g., Paul Goble, Repression by Selective Prosecution, RAdio FrEe EUROPE/RAdio LIBERTY, May 12, 2000 <http://www.rferl.org/newsline/2000/05/120500.html> (discussing tax police inspection of Media-MOST offices, presumably ordered by Russian President Vladimir Putin).

49 On barter generally, see DAvid WOODRUfF, MONey UNMADE: BARTeR AND THE FATE of Russian CAPITALism (1999). On barter as a tax-avoidance strategy, see Kathryn Hendley, Barry Ickes \& Randi Ryterman, Remonetizing the Russian Economy, in RUSSIAN ENTERPRISE ReForm: Policies to Further the Transition 101 (Harry G. Broadman ed., 1999) (World Bank Discussion Paper No. 400); Alan Reynolds, Russia and Japan in the Shadow of Tax Policy, JoBS AND CAPITAL, Summer/Fall 1998, at 50 (published by Milken Inst.). For a non-tax explanation for barter, see Clifford G. Gaddy \& Barry W. Ickes, Russia's Virtual Economy, ForeigN AFF., Sept./Oct. 1998, at 53. 
that involves multiple intermediaries and is designed to hide true profits from the tax inspectors, the opportunities for insiders to skim profits are endless and the prospects of catching them are remote.

Hidden transactions also preclude using the courts to enforce contracts. If the true contract between two companies involves a large quantity of goods at a high price, while the nominal contract (prepared for the tax inspectors) specifies a small quantity at a much lower price, and one party defaults, the other can hardly go to court to enforce the true deal.

b. Corruption. The need to pay multiple bribes-to tax inspectors, to customs officials, to the police not to harass you, to the many bureaucrats from whom you need a permit to operate-has landed Russia near the bottom of most lists of official corruption. ${ }^{50}$ Russia may be better than Nigeria, but not by much.

Moreover, while payoffs to organized crime provide protection against similar demands by competing Mafia groups, payoffs to government officials don't protect you against demands by other officials. The combined bribe demanded by multiple officials can be far larger than a "monopoly" official, seeking to maximize long-term income, would demand. ${ }^{51}$ Corruption and the unfriendly bureaucracy are closely connected. Corrupt officials look for opportunities to enforce picky rules and add new rules.

c. Unfriendly bureaucrats. Russian red tape, often dating from the Soviet era when businessmen needed planning ministry permission to do almost anything, can be overwhelming. An average new business must obtain permission from "20-30 agencies and receive 50-90 approved registration forms." ${ }_{52}$ On average, Russian shops take three months to register (versus three weeks in Poland), are inspected 83 times per year (versus half that in Poland), and are fined $19 \%$ of the time (versus 9\% in Poland). ${ }^{53}$ Disfavored

50 See, e.g., Transparency International, 1999 Corruption Perceptions Index, available at <http://www.transparency.de/documents/cpi/index.html> (ranking Russia $82^{\text {nd }}$ of 99 ranked countries, with a corruption rating of 2.4 on a 1-10 scale, with lower ratings indicating higher corruption).

${ }^{51}$ See Andrei Shleifer \& Robert W. Vishny, Corruption, 108 Q. J. ECON. 599 (1993).

52 Harry G. Broadman, Reducing Structural Dominance and Entry Barriers in Russian Industry, REV. IND' L ORG. (forthcoming 2000).

${ }^{53}$ See MCKinsey Global Institute (1999), supra note 56, exh. 33. 
(read: new) businesses are inspected far more often than these averages, and the price of not being fined is usually bribing the inspector. ${ }^{54}$

d. Organized crime. If there is a street-level retail establishment in a major Russian city that doesn't pay a healthy share of revenue for "protection", we haven't heard of it. Arguing too strongly over how much to pay can reduce one's life expectancy, as can complaining to the police, who are likely to be in the pay of the Mafia. This leaves businesses to try to persuade their protectors to leave them enough profit to stay in business.

Many large businesses also engage private security forces. But private security is expensive, offers imperfect protection when goods are transported to market, and can be turned to pernicious use-enforcing price-fixing and market-division agreements with competitors or scaring off competitors. More generally, Russian managers can write off unpaid debts, try to enforce them through ineffective courts, or engage their krysha (8DZT ", Russian for "roof," a slang term for Mafia protection) to collect the bill. They can compete on price and quality or pay the krysha to put competitors out of business. They can pay the bribes demanded by local officials or hire the krysha to negotiate a lower payment. ${ }^{55}$ Yet when managers rely on the Mafia for services like these, they strengthen the Mafia, strengthen government-Mafia ties, shorten managers' time horizons (you could be put out of business next), and contribute to a lawless environment.

If a company stays small, it has a better chance of staying out of sight of tax inspectors, other bureaucrats, and the Mafia. Russia is the only country we know where small businesses routinely avoid publicity and obtain customers only by word of mouth. Business cards commonly contain no telltale address, and often not even a local phone number (the prefix will give away the business's approximate location). Even retail businesses often operate from behind unlabeled doors.

\footnotetext{
${ }^{54}$ See Guy Chazan, Russian Entrepreneurs Fret Over Putin, Wall St. J., Mar. 21, 2000, at A23 (“[M]any small-scale entrepreneurs say their biggest headache is a plethora of overlapping and often competing bureaucracies. In many cases, [regulations are used as] a tool against firms that have fallen out of favor with local authorities.").

55 See Neela Banerjee, Tough Times in Crime Too, Bus. Rev. Apr. 1999, at 16, 17 ("A krysha offers its clients everything from 'office renovations to killing off a business rival, though that costs extra,' says Pavel, a women's clothing importer.”); Simon Johnson, John McMillan \& Christopher Woodruff, Contract Enforcement in Transition (working paper 1999) (in survey on contract enforcement, $48 \%$ of Russian firms report using "an informal agency specializing in such disputes" to help resolve the dispute).
} 
e. Subsidies to unprofitable firms. A rational capital market provides funds to profitable businesses and starves unprofitable ones. The Russian government usually did the opposite-funneling subsidies to money-losing businesses, often by accepting nonpayment of wages, taxes, and energy bills. Subsidies for losses let a controller loot the same asset multiple times. ${ }^{56}$ The explicit and implicit government subsidies to money-losing firms are huge-around $15-20 \%$ of GDP. ${ }^{57}$ Meanwhile, profitable Russian businesses are targets of opportunity for tax collectors, the Mafia, and bribe-seeking bureaucrats. And the products produced by subsidized competitors drive down market prices and lower the profitability of otherwise viable firms.

f. Urban land. Starting a new business or growing an existing one requires land. In most Russian regions, urban land hasn't been privatized. Obtaining land requires bribing government officials, who can then collect taxes from you, tell their Mafia buddies about you, and revoke your land rights if you don't pay enough taxes or bribes. Moreover, insecure land rights mean that businesses won't invest much in immoveable buildings or equipment, and thus won't grow very large or employ many people.

g. Lack of capital. Russians have limited savings and don't trust banks. A recent good reason: In 1991-1993, the government froze private savings held in the state savings bank and confiscated almost all of those savings by paying interest rates far below inflation. About $\$ 100$ billion in savings that might have helped to found new businesses was wiped out, and Russians learned to keep savings away from domestic banks, often in hard currency, and hence unavailable to support new investment.

Those citizens who put savings into the new private banks, often run by kleptocrats, soon regretted that choice. During and after the 1998 ruble crash, a bank run ensued, and many banks refused to honor depositor demands for their funds. The Central Bank was in no hurry to straighten out the mess, and

56 See McKinsey Global Institute, Unlocking Economic Growth IN Russia 24 (1999) ("[T]he continuous flow of implicit government subsidies . . . makes the endless milking of [nonviable] assets (with the complicity of local authorities) a more attractive proposition to managers than selling cheap to industry consolidators ....”).

57 See Brian Pinto, Vladimir Drebentsov \& Alexander Morozov, Give Growth and Macroeconomic Stability in Russia a Chance: Harden Budgets By Eliminating Nonpayments (working paper 2000). 
allowed bank controllers to strip the banks of their remaining assets, leaving depositors and creditors with an empty shell. ${ }^{58}$

h. A dysfunctional banking system. It was not for nothing that Jeffrey Sachs once called Central Bank head Viktor Gerashchenko perhaps the worst central banker in history. He not only mishandled monetary policy; he tolerated and perhaps personally benefitted from a system in which the reported (bribe) cost of transferring funds through the banking system from one part of Russia to another was around $15 \%$ of the amount transferred. That drove business activity underground and made it hard to conduct business across long distances at all.

i. Unfriendliness to foreign investment. Foreign investors face additional problems, including ever-changing currency regulations that make it hard to withdraw money once invested and ensure that the Central Bank takes a cut of every dollar that is withdrawn. The regulations don't stop capital flight, because the kleptocrats and other major players exploit loopholes or bribe their way out of compliance. Instead, they discourage honest capital from entering.

j. Labor laws. Russia's labor laws, dating from its Communist days, formally prohibit most layoffs, and in practice make them expensive. Even top managers can't be easily fired. Standard practice is to pay employees to leave voluntarily. Many businesses don't pay their employees on time or in full, but honestly run or foreign-owned businesses can't escape so easily. ${ }^{59}$

\section{Macroeconomic Performance}

A second key factor that affects firm controllers' expected gains from value creation, and thus the level of self-dealing they will engage in, is a country's macroeconomic performance. Macroeconomic performance interacts with the business climate and with asset stripping. The worse the business climate, the more asset stripping will take place, and the worse macroeconomic performance will be. In a vicious circle, poor macroeconomic

\footnotetext{
58 On the Central Bank's ineffective response to bank failures, see Mark Whitehouse, Frustration Soars for Russian Bank Depositors: Moscow Does Little to Resolve Crisis, WALL ST. J., Apr. 8, 1999, at A14. For an asset stripping example, see text accompanying note 37 supra.

59 As one Western law firm recently warned its clients, when "Russian employees sue foreign companies in Russian courts for wrongful termination, they usually win." Mary Holland \& Olga Kozyr, Downsizing Russian-Style, CIS LAwNotes (Patterson Belknap Webb \& Tyler), Mar. 1999, at 6,7 .
} 
performance then further depresses firm profitability and encourages asset stripping. ${ }^{60}$

Our overall judgment is that Russia's macroeconomic policy decisions were sometimes poor but not terrible. Inflation was brought under reasonable control by around 1995, and the budget deficit was tolerable. On the other hand, high real interest rates chilled investment. And from 1995 through 1998, Russia's central bank managed the ruble/dollar exchange rate, letting the ruble gradually slide against the dollar. The ruble's roughly $75 \%$ devaluation in 1998 suggests that the ruble was overvalued before devaluation, which made Russian businesses less competitive. ${ }^{61}$

Some evidence of the overall chill on business, from both micro and macro factors: At a time when business opportunities should have been abundant and workers readily available, the number of small Russian businesses dropped from 877,000 in 1995 (many started in an early 1990s burst of enthusiasm) to 829,000 in $1997 .{ }^{62}$ On a per capita basis, this is about a quarter of the number of small American businesses. ${ }^{63}$ The Russian pattern of firms not paying workers for months on end is possible only because workers have no alternative. In successful post-Communist countries, even state-owned firms have shrunk payrolls and improved productivity. In Russia, it is common for a privatized firm to have cut production by $50 \%$ since 1991 , but to have cut employment by only $10 \%$.

Capital flight is another good measure of the investment climate. For those who follow Russia's woes, the $\$ 10$ billion Bank of New York money laundering scandal that broke in 1999 was uninteresting. We merely learned how a small fraction of the money that has left Russia (a ballpark estimate is $\$ 200$ billion

${ }^{60}$ Simon Johnson, Peter Boone, Alasdair Breach \& Eric Friedman, Corporate Governance in the Asian Financial Crisis (working paper 1999), argue that such a vicious circle can help to explain the 1997-98 financial collapses in a number of countries.

${ }^{61}$ The exchange-rate problem was suggested to us by Gerhard Pohl. He sees the too-high ruble valuation as central to Russian firms' troubles. In contrast, we see it as only one factor that affected profit opportunities. Also, the decline in the sustainable ruble/dollar exchange rate partly reflects the declining productivity of Russian industry. Thus, the ruble's overvaluation may be as much a result of other factors as an independent cause of low profitability.

62 See Robert Orttung, Newly Elected Regional Governors Grapple with Moscow, in ANNUAL Survey of EASTERn Europe AND THE Former Soviet Union: 1997-THE Challenges of INTEGRATION 285 (Peter Rutland ed., 1998).

63 Employment data tell a similar story. See Broadman (2000), supra note 52 (small and medium Russian enterprises employ only $13 \%$ of workers, compared to $53 \%$ in the United States and $37-58 \%$ in selected other transition economies). 
[VOL. 52:XXX

during the 1990s) happened to leave. The money is still leaving, just by another route. ${ }^{64}$

The lack of foreign investment is a further measure of the business climate. Russia's official statistics estimate cumulative foreign direct investment at a scant $\$ 13$ billion from 1992 through 1999. Even the major oil companies, no strangers to tough political environments, have invested little and lost much of what they invested. ${ }^{65}$

\section{Other Factors}

Some additional important market-wide factors that affect the upside from a value creation strategy, and thus the likelihood of looting:

a. An inefficient capital market. The harder it is to raise capital or sell one's stake at a fair price, the less the incentive to build firm value. In Russia, public offerings at fair value weren't possible because disclosing true profits to investors meant disclosing them to tax inspectors also. A private buyer can be shown a company's true books. But the general prevalence of self-dealing makes it hard to persuade investors that a particular controller is (or will stay) honest. Russian firms also can't address investor suspicions by getting auditors to vouch for the company's books, since the real books are unofficial.

b. Uncertainty and controllers' effective time horizons (or implicit discount rates). A value-increasing strategy often requires investing capital in the near term, and generates additional cash only in the long run. Economic and political uncertainty makes long-term profits less certain, and hence less valuable.

${ }^{64}$ On the Bank of New York scandal, see, e.g., Andrew Higgins, Alan S. Cullison, Michael Allen \& Paul Beckett, Brash Russian Banker and His Deals are Key to Laundering Probe, WaLl ST. J., Aug. 26, 1999, at A1; Andrew Higgins, Paul Beckett \& Ann Davis, A Scheme for Ducking Taxes May Be a Key in Russia Money Probe, Wall St. J., Sept. 15, 1999, at A1. For capital flight estimates, see Timothy L. O’Brien, Follow the Money, If You Can, N.Y. Times, Sept. 5, 1999, § 3, at 1. On continued capital flight, see Mark Whitehouse, In Russia, Capital Flight Continues Unabated, WaLL ST. J., Apr. 19, 1999, at A19.

\footnotetext{
${ }^{65}$ On overall foreign direct investment, see Troika Dialog Research, Foreign Direct INVESTMENT (2000) (reporting data from the State Statistics Committee). On oil sector investment, see Jeanne Whalen \& Bhushan Bahree, How Siberian Oil Field Turned Into a Minefield, Wall St. J., Feb. 9, 2000, at A21 (estimating foreign investment in the oil sector at $\$ 3.9$ billion since 1990).
} 
c. Product market competition. Strong competition provides incentives to restructure enterprises and reduces the rents that a controller can loot. In Russia, multiple factors weakened product market competition: privatized enterprises were often monopoly providers in their region; the poor business climate discouraged new entry; trade barriers limited import competition; poor transportation and state-owned local distribution monopolies limited import and interregional competition. ${ }^{6}$

\section{Firm-Specific and Controller-Specific Factors}

In addition to these market-wide factors, a number of factors that were specific to particular firms, or particular controllers, affected the likelihood that a firm's controllers would choose self-dealing as their dominant strategy.

a. Firm profitability. The more profitable a firm is (holding constant the market-wide factors discussed above), and the stronger its growth opportunities, the greater the opportunity cost from self-dealing. Privatizing non-viable firms was an open invitation to loot them.

b. Managerial skill. Poor management reduces a firm's expected earnings, and thus reduces the opportunity cost of self-dealing. Voucher privatization left the old managers in control. Many could muster the skill to strip assets but were incapable of adapting to a competitive market, even if they wanted to.

c. Separation between control and cash flow rights. The smaller the controller's percentage holdings of cash flow rights and the weaker his hold on future control, the smaller the foregone gain from creating value, while the benefits of self-dealing remain the same. From this perspective, voucher privatization is inherently dangerous because it separates control from cash flow rights, not only for the largest firms, for which this separation is hard to avoid, but for mid-sized firms that often have concentrated ownership in developed economies. Pyramid structures or dual-class voting structures that let controllers maintain control with a fraction of a firm's cash flow rights further

\footnotetext{
${ }^{66}$ On barriers to competition, see Broadman (2000), supra note 52. On the correlation between competition and productivity, see J. David Brown \& John Earle, Competition and Firm Performance: Lessons from Russia (working paper 2000), available in Social Science Research Network at <http://papers.ssrn.com/paper.taf?abstract_id=222229>.
} 
encourage asset stripping. Yet pyramid structures were built into many of Russia's largest enterprises.

With no constraints on self-dealing, honest management and dispersed ownership are an unstable combination. A controlling stake is worth more to a self-dealer, who will extract $100 \%$ or more of the firm's value from $51 \%$ of the shares, than to an honest owner who will keep only his prorata share of the firm's profits. Bad owners will thus tend to drive out good ones. ${ }^{67}$

Letting voucher investment funds aggregate the ownership stakes of individuals lets the funds provide a counterweight to managerial control of firms, but recreates the self-dealing problem at a different level-investment fund controllers can strip assets both from the funds and the companies that the funds control. As we argue in Part V.C, investment fund managers are more likely than company managers to find asset stripping attractive.

d. Prosecution risk and effective time horizons. Economic and political uncertainty makes time horizons short (implicit discount rates high) for all managers. A controller who pursues a self-dealing strategy faces a still shorter horizon (a higher implicit discount rate), because of the risk that a future government will prosecute the controller for current self-dealing. This risk doesn't affect the firm's value, but reduces the value of the controller's stake in the firm. The Russian kleptocrats, having gotten the money to buy major firms in questionable ways, already faced future prosecution risk, which enhanced the attractiveness of asset stripping.

e. The controller's morals. Our informal model of the asset stripping decision assumes an amoral controller. In the real world, morals matter. Some controllers will seek to create value rather than steal it, as long as they have decent prospects of doing so. Others will see skimming as a quick way to generate a handsome return on investment, and won't evaluate whether a valuecreating strategy might be optimal in the long term. Give control of an enterprise to a crook and he's likely to loot it, whatever its long-term prospects.

In Russia, market-wide and firm-specific factors combined to make selfdealing the strategy of choice for many otherwise viable firms. Self-dealing was easy, running a business for profit was hard, growth prospects were dim, voucher privatization separated control from cash flow rights, controllers' time

\footnotetext{
${ }^{67}$ Lucian Arye Bebchuk, A Rent-Protection Theory of Corporate Ownership and Control (Nat'1 Bureau of Econ. Research Working Paper No. W7203, 1999), available in Social Science Research Network at <http://papers.ssrn.com/papaer.taf?abstract_id=203110>.
} 
horizons were short, capital markets were rudimentary, managerial skill was scarce, unprofitable firms were subsidized while profitable ones were heavily taxed, and many businesses were sold to crooks who were predisposed to selfdealing.

\section{E. Mass-Privatized Enterprises: Manager Theft and Incompetence}

Voucher privatization left Communist-appointed managers in control of most privatized enterprises. The privatizers hoped that outside investors would invest in salvageable firms and profit by installing better management. That happened in a few cases. Sometimes outsiders reached an accord with the company's managers to buy a stake directly from the company; sometimes they bought controlling stakes in the market or by hiring agents to stand at the company's gates and make offers directly to employees. Occasionally, managers sought outside investors and accepted oversight in return.

But more often, enterprise managers acted in dubious ways to acquire more shares and thereby cement their control. Managers had the easiest access to employees' shares, and often bought them at very low prices, sometimes by threatening retribution if the employees didn't sell. Sometimes shares were bought with company funds, but the managers ended up with the shares. Other times, managers siphoned funds from the company through self-dealing, which they used both to buy employee shares and to improve their own standard of living. ${ }^{68}$

Not infrequently, manager self-dealing compromised the firms' viability. Russia's coal industry offers an example. Many coal-mining firms were doomed to fail. But even potentially profitable firms were sometimes bankrupted by crooked managers. Common skimming techniques included: selling the coal to an intermediary at below-market prices; buying mining equipment at inflated prices; and paying workers with vouchers redeemable at the company store, which sells goods to this captive market at above market prices; with the managers in each case pocketing the difference. Coal workers and their unions, instead of asking where the cash went, periodically go on strike against the Government for unpaid back wages, sometimes shutting down railways to dramatize their claims.

\footnotetext{
${ }^{68}$ For a list of 27 techniques used by Russian managers to cement their control, "apart from the purely criminal ones," see Alexander Radygin, Ownership and Control of the Russian Industry, in Organization for Economic Co-operation and Development, Corporate Governance in Russia (Conference Proceedings 1999) <http://www.oecd.org/daf/corporateaffairs/governance/roundtables/in-Russia/1999/index.htm>.
} 
An irony: Privatized land, while valuable for new businesses, would have been a mixed blessing if coupled with mass privatization. Land was the most valuable asset of many businesses. If salable, it often would have been sold cheaply to insiders, robbing shareholders of some of the value that their enterprises otherwise retain.

Not every privatized enterprise was run by crooks. But many were, and many managers who started out honest changed their minds because they saw what their fellow managers were able to get away with; the tax system demanded that profits be hidden (which made them easy to steal); they saw the Mafia and dishonest managers becoming wealthy while they struggled to survive; and the authorities were too corrupt to do anything about obvious theft. Others, discouraged by the hostile business environment, sold out to crooks, who could earn a swift return on their investment in ways that honest managers couldn't. Honest and dishonest behavior alike can be contagious, and Russia fell into a dishonesty equilibrium. ${ }^{69}$

Hard data on the extent of looting of mass privatized enterprises isn't available. Our own qualitative sense: Transfer pricing schemes and other dodges to hide profits from tax collectors and minority shareholders are all but universal. A few controllers invest some of the hidden profits in new capital equipment, but many more pocket the profits, often offshore. Total business investment is very low. We discuss in Part IV.B the mixed evidence on whether privatized firms show higher productivity than non-privatized firms.

\section{F. Major Enterprises: Kleptocrat Looting}

The enterprises that were privatized through voucher privatization were large in number, but often small in value. But there was enormous value in Russia's natural resources companies, related companies (steel and aluminum mills), and power and telephone companies. The government sold at most minority stakes in these companies during voucher privatization, and sold controlling stakes later, through loans-for-shares and other "auctions." Estimates of these companies' value, if permitted to sell their products at market value, run to maximize profit, and valued at developed country multiples, are often staggering. Table II gives some rough values (precise estimates aren't possible).

\footnotetext{
69 See Paul J. Zak \& Stephen Knack, Trust and Growth (working paper 1998), available in Social Science Research Network at <http://papers.ssrn.com/paper.taf?abstract_id=136961> (modeling a separating equilibrium, in which countries can be characterized as either high or low trust).
} 
How then, can Russia have a total market capitalization at September 1999 of only around \$20 billion? How can the government be unable to pay the \$2 billion it owed to the IMF in 1999 and unable to timely pay its own pensioners and employees the modest amounts they are owed?

An inescapable answer is theft of these companies' value on a massive scale by the kleptocrats who acquired them. Theft at the time of sale, by buying controlling interests for a tiny fraction of fair value; followed by extensive selfdealing that left many of Russia's most valuable companies unable (or unwilling) to pay taxes, pay their workers, or reinvest.

Russian share prices can be understood as out-of-the-money options: Investors expect that the firm's entire value will likely go to the government or the firm's controllers. Minority shares still have some value because there is a small positive probability of realizing a return sometime in the future. 
Table II

September 1999 Value Estimates for Major Russian Companies

Rough value estimates for selected major Russian companies, if run to maximize profit, taxed on that profit at a $33 \%$ marginal rate, permitted to sell their products at world prices, and valued at developed market multiples, provided to us by James Fenkner of the Troika Dialog investment bank. Value estimates for oil and gas companies are based on $\$ 13$ per barrel of oil reserves (or gas equivalent); for electric companies on $\$ 795,000$ per megawatt of generating capacity; for steel companies on $\$ 148$ per ton of capacity; for aluminum companies on $\$ 2793$ per ton of capacity; for Norilsk Nickel on $.085 \times$ value of reserves at current commodity prices; for Rostelecom on $3.3 \times$ book value of property, plant and equipment; for Sberbank on $3.1 \times$ book value of as sets; for Aeroflot on $\$ 16.5$ million per plane.

\begin{tabular}{|llcc|}
\hline Company & Industry & $\begin{array}{c}\text { Value at Western } \\
\text { Multiples (\$ } \\
\text { billions) }\end{array}$ & $\begin{array}{c}\text { Market } \\
\text { Capitalization } \\
\text { (\$ billions) }\end{array}$ \\
\hline Gazprom & natural gas & 1960 & 4 \\
LUKOil & oil & 195 & 5.5 \\
Yukos & oil & 170 & 0.3 \\
United Energy & electricity & 110 & 3.1 \\
Systems & & & \\
Surgutneftegaz & oil & 91 & 4.4 \\
(producing co.) & & & 0.4 \\
Tatneft & oil & 75 & 0.4 \\
Sberbank & bank & 60 & not traded \\
Tyumen Oil & oil & 47 & 0.8 \\
Mosenergo & electricity & 12 & 0.4 \\
Irkutskenergo & electricity & 10 & 0.5 \\
Norilsk Nickel & nickel & 9 & 0.9 \\
Rostelecom & telephone & 5 & 0.03 \\
Bratsk Aluminum & aluminum & 2.3 & 0.08 \\
Krasnoyarsk & aluminum & 2.2 & 0.09 \\
Aeroflot & airline & 2 & 0.04 \\
Magnitogorsk & steel & 1.8 & 0.08 \\
Seversal & steel & 1.7 & $\mathbf{2 0 . 8}$ \\
\multicolumn{1}{c}{ Total } & & $\mathbf{2 7 5 4}$ & \\
\hline
\end{tabular}


Privatization proponents argued that privatization would put control of Russia's major companies in the hands of competent businessmen, who had incentives to restructure these enterprises, replace managers who couldn't make the transition to a market economy, and make the investments needed to improve productivity. The kleptocrats devoted themselves instead to skimming profits from their companies; starving them of funds (to the point where many were unable to pay their workers or their tax bills, let alone invest in new equipment); replacing managers who resisted the skimming (or threatening/bribing them into submission); and shooting managers or local government officials who resisted too strongly.

This story can only be told through anecdotes. We offer five below-hopefully enough to convince the reader that our strong words are justified. For the first four, we have firsthand knowledge of the shenanigans. The fifth, Gazprom, is simply too big to be left out.

Khodorkovski/Yukos: We recounted above the example of Yukos, whose 1996 oil revenues were reported at $\$ 8.60$ per barrel, about $\$ 4$ below what they should have been, with the rest presumably skimmed. But this was only part of Yukos' activity. Yukos owned several operating subsidiaries, each with large minority interests. Yukos purchased oil from these subsidiaries at even lower prices, averaging around $\$ 7.50$ per barrel-low enough so that these subsidiaries, with combined pretax profits of around $\$ 1$ billion before Yukos acquired control, were soon reporting minimal profits or outright losses, and defaulting on their tax payments. Yukos had bled them of whatever cash they had. ${ }^{70}$ The subsidiaries' sale of oil to Yukos, without approval by the subsidiaries' minority shareholders, was a flagrant violation of the company law, but no matter. No one sued, and if they had, well, judges could be bought or their decisions ignored. The transactions were flagrant enough to prompt the Russian Securities Commission to investigate the dealings between Yukos and its subsidiaries. But the investigation went nowhere, perhaps because the Commission didn't have the staff to pursue it, or because it was warned off by Khodorkovski's government allies. ${ }^{71}$

Khodorkovski's ambition exceeded his reach, however. In 1997 and 1998, he borrowed heavily from Western banks, using Yukos shares and guarantees

${ }^{70}$ See Joseph Kahn \& Timothy L. O'Brien, For Russia and Its U.S. Bankers, Match Wasn't Made in Heaven, N.Y. TIMES, Oct. 18, 1998, at A1 (reporting on Yukos' dealings with subsidiaries).

${ }^{71}$ See Geoff Winestock, The Quixotic Technocrat, Moscow TIMES, Mar. 31, 1998 (Securities Commission head Dmitri Vasiliev says that he was dissatisfied with Yukos' response to the Commission's investigation, but the Commission had no power to do any more). 
from Yukos' subsidiaries as collateral. When the Russian ruble collapsed in mid-1998, Khodorkovski's Bank Menatep, like most major banks, was heavily exposed because of investments in ruble-denominated Russian government bonds. If one counts his offshore wealth, Khodorkovski surely could have weathered this storm, but he chose instead to let Menatep and Yukos sink. Yukos defaulted on its loan payments, which meant that $30 \%$ of its shares would soon be seized by Western lenders. But Khodorkovski still controlled Yukos for the moment, and he used that control to strip Yukos of its real value-ownership of its oil producing subsidiaries.

At each major subsidiary-Tomskneft, Yuganskneftegaz, and Samaraneftegaz - each worth many billions of dollars based on their oil reserves-Yukos proposed for shareholder approval the following package of proposals, with minor variations:

(i) A massive new share issuance to obscure offshore companies, at dirt-cheap prices that valued the companies at $1 \%$ or less of their true value, and perhaps $10 \%$ of their depressed trading prices. Even that modest amount would be paid not in cash but in promissory notes issued by other Yukos subsidiaries, of dubious legality and even more dubious value. Enough shares were to be issued (between $194 \%$ and $243 \%$ of the previously outstanding shares) to transfer control from Yukos to the offshore companies.

(ii) A multiyear agreement obligating the subsidiary to sell its output to the offshore companies at the laughable price of 250 rubles per ton (around $\$ 1.30$ per barrel at mid-1999 exchange rates, and headed lower as the ruble depreciates against the dollar).

(iii) Shareholder approval of large asset transfers to still other obscure companies, including both past and unidentified future transactions.

Shareholders who opposed these proposals were given the opportunity to sell their shares back to the company at prices that valued the three companies, with proven oil and gas reserves of around 13 billion barrels of oil equivalent, at a total of $\$ 33$ million- $\$ .0025$ per barrel of proven reserves. No, this is not a misprint. $^{72}$

\footnotetext{
${ }^{72}$ For pieces of this story, see Selected Documents in Regard to Minority Shareholders Rights Abuses in YUKOS's Production Subsidiaries (May, 31, 1999) (materials presented by Michael Hunter, President of Dart Management Inc., a major investor in the Yukos subsidiaries, at OECD Conference on Corporate Governance in Russia (Moscow, June 1, 1999)); Alan S. Cullison, Russian Firm Bars Minor Holders, Passes Contentious Share Increase, Wall ST. J., Mar. 24, 1999, at A21; David Hoffman, Out of Step With Russia? Outsider's Battle over Stake in Oil Giant Offers a Glimpse of Nation's Uncertain Capitalist Ways, WASH. Post, Apr. 18, 1999, at H1; Alan S. Cullison, Yukos
} 
To be sure, Yukos needed shareholder approval for this raw theft. Yukos owned only $51 \%$ of the shares in the subsidiaries, and needed $75 \%$ of the votes of the shareholders who participated in a shareholder meeting to authorize the share issuance (plus a majority of the votes of noninterested shareholders). Khodorkovski's solution was bold, if not exactly legal: The day before the subsidiaries' shareholder meetings, Yukos arranged for a compliant judge to declare that the minority shareholders were acting in concert, in violation of the Antimonopoly Law. The judge disqualified everyone but Yukos and its affiliates from voting. When minority shareholders arrived at the meetings, they were greeted by armed guards; most were barred from voting or attending on the basis of this court order. Yukos' shares were voted and were counted as noninterested; the proposals all passed. Having used Yukos' voting power to ram through these proposals, Khodorkovski then transferred Yukos' remaining shares in two of the three oil-producing subsidiaries to offshore companies.

Maybe, if oil prices stay strong, Khodorkovski will put Yukos back together. Maybe in a few years, an appellate court will rule that all this was illegal. But the initial lawsuits have been abandoned. And in the meantime, Khodorkovski will have stolen billions through below-market sales of the subsidiaries' oil.

Besides, opposing Yukos can be bad for one's health. The mayor of Nefteyugansk was murdered in 1998, shortly after he publicly demanded that Yukos subsidiary Yuganskneftegaz pay its local taxes and back wages. ${ }^{73}$ In 1999, Yevgeni Rubin, the head of a company which had won a lawsuit against Yukos, had his car blown up near his home, with armed attackers waiting to finish off anyone who survived the bomb. By chance, he wasn't inside, but his bodyguards were less fortunate. ${ }^{74}$

Transfers Two Oil Units to Offshore Firms, WALl St. J., June 4, 1999, at A12; Alan S. Cullison, Vanishing Act: How Oil Giant Yukos Came to Resemble an Empty Cupboard, Wall St. J. EuR., July 15, 1999, at 1; Alan S. Cullison, Russian Share Shuffle Maddens Investors, Wall St. J., July 23, 1999, at A12. Yukos eventually settled with Kenneth Dart, reportedly buying his shares for over $\$ 100$ million_far above market value, but still far below their true value. See Jeanne Whalen, Russia's Yukos to Buy Dart Stock, Ending Long Feud, WAll St. J., Dec. 21, 1999, at A16.

73 See, e.g., E, D,6 G@® \& D46 7 @'R@® $7 @$ : 48H 422" >, LH ' (">F8@@DZ>8" 2"8@R4: Fb J \$46FH\&@< <'D', $7 @<<, D F ">H$ [Sergei Topov \& Yuri Konachokov, Conflict Over Nefteyugansk Market Ends in Mayor's Assassination, KOMMERSANT], June 27, 1998 (reporting the murder and the mayor's conflicts with Yukos); \% "*4<4D9"*>46, 7D@ 4 =, LH, $7 @ \& @<@ । 8 " b$ BD' \&*" [Vladimir Ladni, Blood and Oil], Komsomolskaya Pravda], at 2 (speculating that Khodorkovski and Yukos were likely to be behind the attack).

${ }^{74}$ See Grigori Mkrtchyan \& Oleg Luriye, Holiday Contract, E? \%+CS +==? E+7 C+G=? [TOP SECRET], Mar. 1999 (interview with the intended victim, Yevgeni Rubin, about the attack, a prior attack on his life three months earlier, and his conflicts with Yukos). 
Khodorkovski's behavior didn't trouble senior Russian officials. In the middle of the scandal, he accompanied then Prime Minister Yevgeni Primakov on a trip to meet President Clinton (aborted in midair when NATO began bombing Serbia). It did trouble the Securities Commission, which launched an investigation. But the outcome of that investigation was hardly promising. The Chairman of the Securities Commission resigned in disgust, after failing to get the cooperation he needed from other government agencies to bring a court action; the Commission's remaining members approved the share issuances. ${ }^{75}$

Berezovski/Sibneft: Sibneft is another major Russian oil holding company. So far as anyone can tell, it is controlled by Boris Berezovski and his partner Roman Abramovich (and perhaps also by Aleksandr Smolenski). But no one knows for sure, because Berezovski rarely owns shares in his own name, and operates through obscure intermediary companies. Sibneft's main production subsidiary is Noyabrskneftegaz, which in 1997 was $61 \%$ owned by Sibneft. In round numbers, Noyabrskneftegaz earned $\$ 600$ million in 1996 , before Berezovski acquired control of Sibneft, and $\$ 0$ in 1997. Most of the missing $\$ 600$ million showed up as Sibneft profit, even though under the company law, transactions between parent and subsidiary require approval by the subsidiary's minority shareholders, which was never obtained.

Simply appropriating Noyabrsk's profits didn't satisfy Berezovski. At the 1998 Noyabrsk annual general meeting, shareholders were asked to approve a new charter and a proposal to increase the number of "announced" common shares that could be issued by decision of the board of directors. Management announced at the shareholder meeting that it proposed new announced shares equal to an astounding 196,300\% of the current number of issued shares. Virtually no shareholder other than Sibneft voted to authorize these shares, but the authorization squeaked through with the necessary support from $75 \%$ of the shareholders who showed up and voted, perhaps because Sibneft hadn't previously disclosed how many shares it proposed to authorize and some minority shareholders didn't attend the meeting.

Noyabrsk's charter provided for preemptive rights, which let all shareholders buy newly issued shares in proportion to their current holdings.

\footnotetext{
75 See Alan S. Cullison, Russian Watchdog Sues Oil Giant, Seeks Probe of Share Shufflings, Wall ST. J., July 22, 1999, at A22 (Securities Commission to investigate Yukos); Neela Banerjee, Frustrated, Russian Securities Regulator Resigns, N.Y. TIMES, Oct. 16, 1999, at B1 (Vasiliev explains his resignation, saying "It's perfectly clear that we haven't gotten the support of other Government agencies we need in connection with some recent shareholder disputes."); David Hoffman, Russia's Rookie Capitalists Can't Count on Law, WASH. Post, Nov. 4, 1999, at A1 (Securities Commission, without Vasiliev, approves share issuance by Yukos subsidiary).
} 
Noyabrsk's management ignored its charter and issued shares at roughly half of Noyabrsk's trading price (already severely depressed by Sibneft's expropriation of Noyabrsk's profits) to four purchasers with close relationships to Sibneft, ignoring along the way the company law requirements that shares be issued at "market value" and that any transaction with a $20 \%$ shareholder or its affiliated persons be approved by noninterested shareholders.

These actions enhanced Sibneft's trading price at the same time that they depressed Noyabrsk's trading price. Sibneft then announced an exchange offer to swap four Sibneft shares for each Noyabrskneftegaz share held by Noyabrsk's minority shareholders. This exchange rate was around $4 \%$ of the relative value of Noyabrsk and Sibneft, before this sorry saga started. Most minority shareholders accepted the offer-the alternative was no more attractive. One shareholder who sued found the local courts unreceptive. The local appellate court rejected the shareholder's appeal on the astonishing grounds that the lawyer's signature on the appeal papers differed from the signature on the original complaint (it didn't, and it would make no difference under Russian law if it had). The shareholder settled rather than fight a yearslong battle in the upper appellate courts. ${ }^{76}$

Berezovski's behavior hasn't improved since. After consolidating Noyabrskneftegaz, Sibneft announced its intent to behave properly towards minority shareholders in the future, adopted a nonbinding "Corporate Governance Charter," and appointed a high-profile Corporate Governance Advisory Board. ${ }^{77}$ But anyone who believed that one should have remembered the old lyric - "Fool me once, shame on you. Fool me twice, shame on me." In early 2000, a Sibneft affiliate stiffed the European Bank for Reconstruction and Development on a $\$ 58$ million loan, by persuading a persuadable Russian court that it had paid the loan. ${ }^{78}$

\footnotetext{
76 Bernard Black was an advisor to a minority shareholder in Noyabrskneftegaz in the matters described in the text. A fuller account of the litigation can be found in Bernard Black, Shareholder Robbery, Russian Style, ISSUE ALERT, Oct. 1998, at 3 (published by Institutional Shareholder Services). On the exchange rate offered by Sibneft, see Christina Ling, Russia Sibneft Swap Riles Minority Investors, REUTERS, July 2, 1998.

${ }^{77}$ See Sebastian Alison, Russian Oil Co Sibneft Sets Out Policy, ReUTERS, July 16, 1998.

${ }^{78}$ See Andrew Higgins, EBRD Says Dispute Tests Russian Legal System, WALl St. J., Feb. 11, 2000 , at A12.
} 
Like Khodorkovski, Berezovski isn't a safe guy to sue, compete with, or write unflattering stories about. Those who try have a distressing tendency to end up beaten, jailed, or dead. ${ }^{79}$

Potanin/Sidanko: Sidanko is another major Russian oil holding company, which in 1998 was 96\% controlled by Vladimir Potanin through Oneksimbank and its affiliates, especially MFK (Mezhdunarodnaya Finansovaya Kompaniya). Oneksimbank, and its affiliates also held significant stakes in Sidanko's subsidiaries. Since MFK was trying to establish itself as the first major Russianowned investment bank, one might think that Potanin wouldn't tarnish his reputation by diluting the already small minority interest in Sidanko. That expectation, like many Western expectations about how Russian businessmen concerned about reputation ought to behave, turned out to be unjustified. ${ }^{80}$

In early 1998, Potanin decided to kill two birds with one stone-simplify the share ownership structure within the Oneksimbank financial-industrial group and dilute the $4 \%$ minority in Sidanko. The chosen means: Sidanko issued convertible bonds to Oneksimbank affiliates in exchange for their shares in other group companies. The conversion price was around $0.1 \%$ of Sidanko's current market price (this isn't a typo either). The effect was to more than triple Sidanko's outstanding shares, once the bonds were converted, and to dilute the $4 \%$ minority down to $1.3 \%$.

This story had a temporarily not-too-unhappy ending for Sidanko's minority shareholders. The shareholders screamed, the Securities Commission launched an investigation into company law violations, and Sidanko agreed to issue enough shares to minority shareholders at the same low price to compensate for

\footnotetext{
79 See Wolosky (2000), supra note 39, at 30 (head of Omsk refinery, who opposed Sibneft's takeover of Omsk, was killed; Noyabrskneftegaz's head of oil exports was jailed for months without charges); James Michaels, Keeping the Old KGB Busy, FoRBES, Dec. 30, 1996 ("[A]fter you've read the [accompanying Forbes expose of Berezovski, Godfather of the Kremlin, Forbes, Dec. 30, 1996], you will understand why we have omitted [the reporters'] names. . . Berezovsky stands tall as one of the most powerful men in Russia. Behind him lies a trail of corpses, uncollectible debts, and competitors terrified for their lives."); Mark Taibbi \& Mark Ames, All Fired Up: Interview with Leonid Krutakov of Moskovsky Komsomolets, EXILE, Oct. 23, 1999 ("Q: You were beaten twice? Krutakov: Yes, once very severely, after my article on Berezovsky came out. A bunch of guys caught me outside my doorway and beat me there, breaking bottles over my head. . . A And of course they didn't take my wallet, didn't ask for anything. Clearly they were just sending a message.”).

${ }^{80}$ Bernard Black and Reinier Kraakman advised a minority Sidanko shareholder in connection with the dilution effort described in the text. For pieces of the Sidanko story, see Jeanne Whalen, Sidanko Bond Issue Tests Legal Water, Moscow Times, Feb. 10, 1998; Jeanne Whalen, Sidanko Talks Tackle Bond Dispute, Moscow TIMES, Feb. 12, 1998; Jeanne Whalen, Shareholders Right: Round 2, Moscow Times, Feb. 17, 1998; Jeanne Whalen, Sidanko President, Top Managers Quit, Moscow Times, Mar. 17, 1998.
} 
the dilution caused by the convertible bond offering. But investor satisfaction didn't last long. After the ruble crash in mid-1998, Potanin found himself in financial trouble (not counting his offshore assets, anyway). He stripped Oneksimbank of most of its remaining assets and looted Sidanko and its subsidiaries as well. Sidanko's minority shareholders, including BP Amoco, which paid $\$ 571$ million for $10 \%$ of Sidanko (after the shenanigans described above), found their shares nearly worthless. ${ }^{81}$

Zarubezhtsvetmet/Erdenet: We described above Russia's illegal sale of its $\$ 250$ million stake in Erdenet for $\$ 150,000$ by privatizing Zarubezhtsvetmet. Now that Zarubezhtsvetmet's (unknown) owners held 49\% of Erdenet, how would they behave? Would they improve Erdenet's operations or invest in the new refining capacity that Erdenet wanted?

The answer was not long in coming. In early 1998, it was discovered that Erdenet was bankrupt, unable to pay either its taxes or its overdue bills for electric power. Some $\$ 30$ million had disappeared, surely with the connivance of Erdenet's general director, Mr. Elbegdorj. The unpaid electric bills meant the utilities couldn't pay Russia for fuel, leaving Mongolia's capital city, Ulaanbaatar, mostly without heat for several months of a bitterly cold Mongolian winter. The Mongolian government sought to fire Elbegdorj and trace the funds; the Russian members of Erdenet's board of directors refused to cooperate. Their resistance deadlocked the company (which has three Mongolian and three Russian board members) for the better part of a year. Mongolia finally used emergency legislation to wrest control of Erdenet away from Elbegdorj and his Russian accomplices. ${ }^{82}$

Gazprom: Gazprom's wealth is fabulous. Even a conservative $\$ 600$ billion estimate of its market value implies that privatizing this one company, on the basis of one citizen, one share, could have delivered $\$ 4,000$ in value to each citizen. That, plus honest management that delivered that value to shareholders, would without more have redeemed the promise of mass privatization-that the state was returning ownership of its property to the people. Continued state ownership would also have let the government finance its payments to pensioners and employees, while still permitting future privatization.

${ }^{81}$ On the Sidanko bankruptcy, see sources cited in note 40 supra. On Oneksimbank, see Guy Chazan, Russia's Uneximbank is Close to a Deal on Debt, Wall St. J., Nov. 12, 1999, at A15.

${ }^{82}$ Bernard Black was an advisor to the Mongolian State Property Committee in connection with its efforts to regain control of Erdenet and prepared a legal opinion on the legality of Mongolia's actions in replacing Mr. Elbegdorj. 
This was not to be. Who owns how much of Gazprom is a secret, but its managers received a huge cut. In early 2000 , the government still owned $38 \%$, while the managers' official stake was around $35 \%$, most of it held by a small group of people who reportedly received stakes of $1 \%$ to $5 \%$ each-with each percentage point worth multibillions at Western valuations. That left another $25 \%$ in other hands. Some of that ownership can be traced, but much is hidden. Some of the hidden shares are likely also held by Gazprom insiders; how many is anyone's guess. Gazprom chairman and former Russian Prime Minister Viktor Chernomyrdin is rumored to be a major owner. Meanwhile, Gazprom pays little in taxes, despite its wealth and despite IMF complaints that Gazprom is seriously undertaxed. ${ }^{83}$

How (dis)honestly Gazprom has been run is impossible to know from the outside. Its reported revenues are around $\$ 30$ billion per year. Its true revenues are hard to determine, because it faces political constraints on cutting off important nonpaying customers (including Ukraine and Belarus). Still, billions of dollars per year could easily be getting skimmed instead of appearing in Gazprom's financial accounts ; Gazprom has also transferred reserves worth $\$ 30$ billion or so to an unknown company that its managers presumably control. ${ }^{84}$ Gazprom also spends money lavishly—including building a glitzy new Moscow headquarters complex and buying top-of-the-line corporate jets.

Given the anecdotes we have recounted, and many others that we could have told instead (the better known ones include Berezovski's looting of AvtoVAZ and Aeroflot; Trans World Metals' tolling agreements with the Novolipetsk steel mill and all three of Russia's major aluminum refineries; Primorski Krai governor Yevgeni Nazdratenko's takeover of Far Eastern Shipping Co.; and reversal of the Lomonosov Porcelain Factory privatization after foreign investors bought control and sought to oust the factory's

\footnotetext{
${ }^{83}$ For IMF estimates of potential tax revenues from Gazprom, see Dale F. Gray, Evaluation of Taxes and Revenues from the Energy Sector in the Baltics, Russia, and Other Former Soviet Union Countries (Int'l Monetary Fund Working Paper 98/34, 1998).

${ }^{84}$ On Gazprom's cash flow, see Adell Karian, Russia's Dirtiest Secret: Where the Money Goes, RUSSIA J., Aug. 23, 1999 , <http://www.russiajournal.com/start/business/article_26_70.htm> ("Where [Gazprom's] cash flow winds up is anybody's guess, and whether the company's numbers even remotely reflect reality is a question that securities analysts would far prefer to avoid."); Aksenenko Complains Gas Exports Too Cheap, Radio Free Europe/Radio Liberty Newsline, Aug. 30, 1999 (First Deputy Prime Minister Nikolai Aksenenko complains that Gazprom is selling gas cheaply to middlemen, who are making "enormous profits"). On transfer of its reserves, see Craig Mellow, Putin's Problem, InST' L INVESTOR, Apr. 2000, at 44, 50.
} 
managers) ${ }^{85}$ one might ask: Are there any honest major companies left in Russia?

Well, maybe. Some behave better than others. LUKOil and Surgutneftegaz are better respected than other Russian oil companies, and their shares trade at a higher price per barrel of reserves, though still at a small fraction of Western prices. Their managers still steal, just less egregiously. LUKOil's managers recently bought $9 \%$ of its shares from the government for a slender $\$ 200$ million (with funds almost surely obtained by self-dealing); Surgutneftegaz recently proposed merging its holding company (which held 16 billion shares of its principal producing subsidiary) into the producing subsidiary, in exchange for 12 billion subsidiary shares-an instant $25 \%$ dilution of the holding company's minority shareholders. ${ }^{86}$

But gross misbehavior was the norm. The new investment that the privatizers hoped for rarely occurred. The kleptocrats often reneged on investment promises that they made when acquiring shares, or that their companies had made before the kleptocrats acquired them. ${ }^{87}$ The underlying question must be: If privatization of even the largest, most valuable firms

85 On AvtoVAZ and Berezovski, see [authors omitted by Forbes because of concern for their safety], Godfather of the Kremlin?, ForBES, Dec. 30, 1996, at 90. On Aeroflot, see Paul Klebnikov, The Day They Raided Aeroflot, ForbeS, Mar. 22, 1999, at 106; John Tagliabue, Swiss Ask Whether Russian Used Aeroflot to Siphon Millions, N.Y. TimES, Sept. 15, 1999, at A8; Elif Kaban, Russia Suspects $\$ 600 \mathrm{mln}$ Aeroflot Cash Laundered, REUTERS, Oct. 20, 1999. On Trans World Metals, see Erin Arvedlund, Investors, Factory Face Off Over Board, Moscow Times, Feb. 11, 1997; Tom Warner, The Supply Wars of Ukrainian Aluminum, N.Y. TIMES, Aug. 23, 1999, at C2; Neela Banerjee, Swiss Expand Inquiry on Russian Money Flow, N.Y. TIMES, Oct. 14, 1999, at A6. On Nazdratenko and Far Eastern Shipping Co., see Russell Working, Cloak, Dagger and Strong-Arming in the Russian Far East, N.Y. TIMEs, June 24, 1999, at C4; Bruce Ramsey, Red Faces Here Over Visit by a Russian Official, SeAttle Post-Intelligencer, July 24, 1999. On Lomonosov, see Jeanne Whalen, Russia Ousts Foreign Owners of Prized Factory, Wall ST. J., Oct. 12, 1999, at A19; David Lynch, Investor Caught in Russian Tug of War, US A TodAY, Dec. 17, 1999, at 1. For a recounting of many more scandals, see Radygin (1999), supra note 68, 126.

${ }^{86}$ For the market capitalization of LUKOil and Surgutneftegaz, see Table II. On the sale of LUKOil shares, see note 26 supra and accompanying text. On Surgutneftegaz's dilution of holding company shareholders, see Neela Banerjee, Shareholder Value in a Russian Oil Stock?, N.Y. TIMES, Jan. 27, 2000, at C4.

${ }^{87}$ Yukos again provides an example. Shortly after acquiring control of Yukos, Khodorkovski renounced Yukos' contract with Amoco to jointly develop the Priobskoye oil field in West Siberia. See Jeanne Whalen, Pena: Russia Should Respect Its Oil Deals, Moscow Times, Sept. 24, 1997; Jeanne Whalen, Amoco Eyes Sale of Stake in Far North Oil Project, Moscow Times, Nov. 14, 1998. 
produced outcomes like these, can the alternative have been worse? We turn to that question next. ${ }^{88}$

\section{The Counterfactual: What Might Have Happened With Staged PRIVATIZATION AND MORE INSTITUTION BUILDING?}

Some early proponents of rapid privatization of large firms still defend this strategy; others have backed off. ${ }^{89}$ The defenders have responded to our recounting of scandals with two principal assertions. First, they contend that massive theft would have occurred if firms hadn't been privatized. Second, they contend that privatization led to productivity gains at some firms. We consider these arguments to be only partial responses, for several reasons.

The first step in assessing what might have happened is to define a counterfactual. For us, the counterfactual is not just slower privatization of large firms. That might have reduced political backlash against market reforms, but wouldn't have helped the Russian economy much, nor laid the groundwork for later privatization. Ukraine, for example, didn't privatize and is as corrupt as Russia and in even worse economic shape.

A more optimistic counterfactual, that we believe was attainable in the early reform period of 1991-1993, would have included several interrelated steps:

- staging privatization of large firms, while promising managers that their firm will be privatized if the firm performs well enough to justify privatization

- designing the privatization strategy (for example, enterprise leasing, cash auctions instead of voucher auctions, and sale of minority stakes to foreign firms) to produce concentrated instead of dispersed ownership of all but the largest firms

- devoting the political energy that went into rapid privatization instead to building the institutions to control self-dealing, corruption, and organized crime

\footnotetext{
${ }^{88}$ Part III ends our storytelling. This may be an appropriate place to answer a question that readers knowledgeable about Russia have frequently asked us: Having written this article, are we scared to return to Russia? A glib yet serious answer-it's a nice place to visit (quietly), but we wouldn't want to live there anytime soon. And we've chosen for now not to publish in Russia a Russian-language version of this article.

89 The defenders include Andrei Shleifer and Anders Aslund. See ANDREI SHLEIFER \& DANIEL Treisman (2000), supra note 35; Anders Aslund, Russia's Collapse, Foreign Afr. Sept./Oct. 1999, at 64. The backtrackers include Jeffrey Sachs, who now concedes being "overly optimistic about . . mass privatization," and explains: "[W]hen privatization was rushed through via mass voucher schemes, as in Czechoslovakia in 1991 and Russia in 1993, the result all too often was corrupt asset grabs, managerial plunder of enterprises, and paralysis of firms. The voucher holders often ended up with nothing.” Jeffrey D. Sachs, Life After Communism, WaLl St. J., Nov. 17, 1999, at A22.
} 
July 2000

- creating a friendlier business climate, especially a friendlier tax regime.

We discuss below why we believe these steps were at least partly attainable.

Some critics have argued to us that our counterfactual overstates the Russian government's capacity and honesty, even in the early 1990s. They believe that massive theft couldn't have been prevented, with or without privatization. $^{90}$ If they are right, that leaves us with our basic position: If the government is bad enough, rapid large firm privatization won't help or hurt the economy much, compared to available alternatives. But it will still poison the political climate against further reform, reinforce corruption, and, as we argue next, likely facilitate theft at the margin.

\section{A. Did Large-Firm Privatization Make Self-Dealing Worse?}

In Russia and other former Soviet Union countries, much theft from stateowned companies occurred prior to privatization. This theft was even given a polite name-"spontaneous privatization." The counterfactual question is whether theft would have been greater or less if large-firm privatization had proceeded more slowly, and higher priority had been given to controlling selfdealing.

We think the theft was likely worse in fact than in our counterfactual. To begin with, our counterfactual includes devoting political energy to a full-scale effort to control self-dealing. That effort would include prosecuting raw theft and developing the enforcement institutions needed to attack spontaneous privatization less crude than simply walking off with the assets. There was ample public support for prosecuting managers who were lining their own pockets with state assets. Given the awful state of Russian prisons, it might not have taken many exemplar cases to turn many managers' risk-reward calculus toward more honest conduct.

Second, even without this redirection of political energy, there are cases where theft increased as a result of privatization. The market price of Tomskneft, for example, plummeted in 1997 when Yukos acquired a controlling

\footnotetext{
90 This is the principal defense of mass privatization by Dmitri Vasiliev, Deputy Minister in the Russian Privatization Ministry during mass privatization and later head of the Russian Securities Commission, in commenting on this paper at a 1999 conference. But Vasiliev defends only Russia's 1993-1994 mass privatization. He opposed loans-for-shares and similar "auctions" of Russia's largest companies. Andrei Shleifer has also argued to us that our counterfactual is unrealistic, there was "tremendous looting from state enterprises by their managers," and privatization didn't make the looting worse. Letter from Andrei Shleifer to Bernard Black (Sept. 29, 1999).
} 
stake from the government, evidence that investors expected worse treatment from Khodorkovski than from the former managers. By mid-1999, the shares of Tomskneft, other Yukos subsidiaries, and Yukos itself had lost 98-99\% if their former value.

Similarly, the ratio of the market price of Noyabrskneftegaz to the price of its parent, Sibneft, dropped from 100:1 in 1996 to 6:1 in mid-1998 after Sibneft acquired control, as minority investors incorporated ever-lower expectations about how much value Sibneft would leave for them. Sibneft then completed an exchange offer of four Sibneft shares for each Noyabrskneftegaz share. Sidanko also looted its subsidiaries, and then was looted itself, with both Sidanko and its principal subsidiaries ending up in bankruptcy. Reported earnings tell the same story. Tomskneft, Noyabrskneftegaz, and other major enterprises reported large profits under government ownership, which turned to breakeven or outright losses after a kleptocrat acquired control.

Third, many privatized enterprises weren't viable in a competitive market. For these firms, liquidation was inevitable, but mass privatization still had pernicious consequences. Consider an unprofitable firm with assets worth $\$ 1000$ in piecemeal liquidation, and worth $\$ 1500$ if sold to a competitor, who will close the firm but obtain some value from its customer relationships. The government could sell the firm for $\$ 1500$ in a cash auction. If the firm isn't privatized, its managers will sell its movable assets cheaply to an intermediary, earning perhaps $\$ 500$. If the firm is mass privatized, the controllers, who may own only $10 \%$ of the firm's shares, will strip its assets as best they can. They will realize $\$ 1000$ from piecemeal liquidation, and perhaps another $\$ 1000$ in wealth transfers from employees who work but don't receive wages, suppliers who deliver goods but don't get paid, and customers who receive defective merchandise and have no recourse.

Fourth, if natural resource enterprises remained under government ownership, the current profits could be stolen, but the remaining resources could be recovered by a future honest government. With privatization at knock-down prices, not only the short-term flow, but the full long-term stock, was stolen.

Fifth, control mechanisms under government ownership were weak, but still likely stronger than after privatization. Company managers still faced a chain of command to whom they reported. Gross theft might upset one's superiors. There was also possible embarrassment or even a jail term if theft became obvious and was publicly reported.

The theoretical case for privatization rests in part on removing enterprises from political oversight, so that managers' decisions are motivated by profit, not by whatever motivates politicians. As Shleifer \& Vishny argue, "privatization widens the separation between the manager and the politician, and in this way 
stimulates restructuring."91 But that same freedom from state control that facilitates restructuring also facilitates theft, if the manager wants to steal.

Indeed, it's hard to see how one could construct a theoretical model in which privatization promotes restructuring by freeing firms from state control, in which that diminished control does not also permit increased self-dealing. To prevent increased theft, the state would have to devote specialized resources (prosecutors, a strong Securities Commission) to controlling self-dealing. Russia didn't take these steps initially, and once managers and kleptocrats became strong, they opposed controls on self-dealing. The kleptocracy became selfreinforcing.

Moreover, the Russian government would be financially stronger today if it still owned Russia's major natural resources companies. Oil and gas revenues alone would easily cover its foreign debt service and pension and salary obligations. And there would be strong political pressure to use those revenues for these purposes.

\section{B. The Efficiency and Distributional Consequences of Privatization}

Dirty privatization might be justified if it accelerated the restructuring of inefficient state-owned enterprises. Unfortunately, there is little evidence of this. Russian productivity fell sharply during the 1990s. The productivity of the average Russian worker fell from 30\% of the U.S. level in 1992 to only $19 \%$ in 1999. Capital investment has plunged as well, to only $13 \%$ of GDP ( $40 \%$ of the pre-1992 level). ${ }^{92}$

In many countries, case-by-case privatization of state-owned firms, often natural resources firms or monopolies like railroads, telephone, and electric utilities, increased productivity. ${ }^{93}$ But evidence on post-privatization efficiency gains in Russia and other former Soviet Union countries that pursued mass privatization is mixed. As John Nellis concludes in a recent survey:

Evidence-early and fragmentary,but impossible to ignore-from... Armenia, Georgia, Kazakhstan, the Kyrgyz Republic, Moldova, Mongolia, Russia, and Ukraine-shows less promising results:

\footnotetext{
91 Andrei Shleifer \& Robert W. Vishny, The Grabbing Hand: Government Pathologies AND Their CuREs 147 (1998).

${ }^{92}$ See MCKinSEy GLOBAL InSTitute, supra note 56.

${ }^{93}$ For a current survey, see William L. Megginson \& Jeffry M. Netter, From State to Market: A Survey of Empirical Studies on Privatization (N.Y. Stock Exchange Working Paper No. 98-05, 2000), avalable in Social Science Research Network at <http://papers.ssrn.com/paper.taf?abstract_id=158313>.
} 
- Private ownership often does not lead to restructuring ... .

- Some partially state-owned firms perform better than privatized firms.

- In some countries, there are few differences in performance between (wholly) state-owned and privately owned firms.

-In other countries, there are clear performance improvements only in those very few firms sold to foreign investors. ${ }^{94}$

The culprit appears to be, in part, the diffuse ownership created by voucher privatization. Diffuse ownership is associated with less restructuring than any other form of firm ownership, including continued state ownership. ${ }^{95}$

The evidence doesn't suggest that privatized companies perform worse than state-owned companies, on average. They merely don't perform much better, if at all. But that in itself is damning. Enormous political energy was devoted to large-firm privatization, which was seen as a key to economic revival. Ex post, the efficiency gains are so small that economists are debating whether they exist at all. The outcome suggests that political energy might have been better spent elsewhere.

Moreover, we often measure efficiency in terms of the size of the social pie, without regard to who owns which slice. That's too simple in Russia. One Russian tragedy is that wealth differences soared while the social pie was shrinking. Russia's per capita GDP declined by $40 \%$ in the 1990 s, while a standard measure of inequality, the Gini coefficient, soared from around 24 in 1988 to 47 in 1997 (compared to a U.S. level of about 43). The rising Gini coefficient tells us that the bottom half of the Russian population faced an income decline far greater than the $40 \%$ average decline. The percentage of Russians living in absolute poverty (by standard measures) grew from a small fraction of the population in 1989 to an estimated 55 million (37\% of the population) in 1999. ${ }^{96}$ The billions held offshore by a few kleptocrats have far

${ }_{94}$ Nellis (1999), supra note 2, at 16; see also Simeon Djankov \& Peter Murrell, Enterprise Restructuring in Transition: A Quantitative Survey (working paper 2000) (finding no statistically significant effect of privatization on firm restructuring for former Soviet Union countries); Megginson \& Netter (2000), supra note 93 (abstract) ("those countries which have chosen the mass (voucher) privatization route ... face ongoing efficiency problems as a result").

${ }^{95}$ See Djankov \& Murrell (2000), supra note 94, fig. 1.

96 On inequality and Gini values, see Branko MILANOvic, INCOME, INEQUALITY, AND Poverty During the Transition from Planned to Market Economy (World Bank 1998) <http://www.worldbank.org/research/transition/inequal.htm〉; Stiglitz (1999), supra note 4, fig. 2; Elizabeth Brainerd, Winners and Losers in Russia's Economic Transition, 88 AMER ECON. Rev. 1094 (1998). On poverty rates, see Milanovic (1998), supra; Michael R. Gordon, Hardened to Hardships, Russians Simply Stretch the Rubles Further, N.Y. TIMES, Aug. 22, 1999, at A1. 
less social value than the same amount distributed broadly among the Russian population.

Privatization doesn't have to be all or none. Our judgment is that Russia's privatization of small shops and businesses (basically given to their employees) was a positive step. Mass privatization of medium and larger enterprises was neither a clearly good nor a clearly bad step. It produced many viable companies and some decent owners, though with a tendency for bad owners to buy or squeeze out good ones. But loans-for-shares and other rigged sales of the largest enterprises were a failure both economically and politically. They produced bad owners who chose asset stripping over value creation, almost without exception.

\section{Institution Building}

Section $B$ addressed whether rapid large-firm privatization is likely to produce productivity gains compared to continued state ownership, holding constant the (bad) institutional environment. However, our counterfactual does not hold constant the institutional environment. Instead, it assumes that the political energy devoted to privatization goes instead into building the institutions to support privatization.

There's no way to know by how much better laws and institutions could have reduced self-dealing, had they preceded or at least accompanied privatization. Good tax laws, a serious anti-corruption program, and credible enforcement against insider theft of company assets might have made a major difference. Good (and sometimes enforced) capital markets laws might have helped to establish baseline expectations about behavior. Conversely, their early absence contributed to a lawless climate, in which managers could justify selfdealing by claiming (sometimes correctly) that they had done nothing illegal.

Perhaps enforcement of capital markets rules would have been equally minimal if the rules and regulators had come first. Or perhaps Russia would have found a different path-dependent equilibrium, with better and more vigorously enforced capital markets laws, had good laws and a strong securities commission preceded privatization. We cannot say. What we can say is that bad owners reinforce corruption and create pressure for weak enforcement, and this pressure contributed to the non-enforcement of capital markets laws that is the norm today. ${ }^{97}$

\footnotetext{
${ }^{97}$ For a generalization of this argument, see Gerard Roland, Corporate Governance Systems and Restructuring: The Lessons from the Transition Experience; working paper presented at the Annual Bank Conference on Development Economics (World Bank 2000).
} 
At the margin, stronger controls on skimming would have reduced the expected return to skimming, while improving the firm's expected long-term value (because the same government that was building stronger institutions was less likely to expropriate that value). That would have changed at least some managers' decisions to skim instead of build value.

\section{Staged Privatization: Enterprise Leasing and Alternatives}

Our counterfactual also assumes a program of staged privatization, in which companies whose managers have proven both the company's viability and their own honesty are privatized first, and privatization is designed to produce concentrated rather than dispersed ownership. These steps would have reduced the likelihood that enterprise controllers would strip them rather than build value; would have given the enforcers a less overwhelming task; and would have facilitated the virtuous cycle that the privatizers hoped for, in which managers of privatized enterprises support good and enforced commercial and capital markets laws, and their mostly good behavior establishes norms for manager conduct.

Staged privatization can produce value-creation incentives similar to immediate privatization. If the government promises managers that their firm will be privatized if the firm's results justify this, that promise of future wealth can provide incentives similar to those created by immediate privatization, without the loss of state control over self-dealing that privatization entails. ${ }^{98}$ Such a promise won't be fully credible, but semi-credible promises could have been made, and were being made, prior to mass privatization. For example, that the government could reserve a percentage of the company's shares for its managers. The expectation of receiving shares in the future can create incentives similar to restricted stock or stock options that vest over time, which are commonly used as incentive compensation in developed economies.

For us, staged privatization has four key features:

- The promise of future privatization, contingent on performance, can create profit incentives comparable to those created by immediate privatization.

- Bureaucratic controls are loosened firston operating decisions, and only later on self-dealing, as the infrastructure to control self-dealing within fully private enterprises is created.

- Privatization is designed to produce concentrated ownership of all but the

\footnotetext{
${ }^{98}$ See Michael Ian Cragg \& I.J. Alexander Dyck, Management Control and Privatization in the United Kingdom, 30 RAND J. ECON. 475, 477 (1999) (reporting that productivity gains by privatized British firms were achieved primarily in the 5 years prior to privatization).
} 
largest firms, to reduce controllers' incentives to expropriate minority shareholders.

- If only successful, honestly run enterprises are privatized, a virtuous spiral that encourages good managerial behavior can emerge, instead of the downward spiral that resulted from mass privatization without controls on selfdealing.

Staged privatization would not have been perfectly clean. Some companies would have been privatized as a result of bribery rather than performance. But the tilt would still have been toward privatizing the more successful firms first.

\section{Enterprise Leasing}

A promise of future privatization of profitable firms could take many forms. But we need not speculate on its exact form because such promises were being made during the perestroika era, through a program called "enterprise leasing" that began in 1989. The privatizers killed enterprise leasing in 1992, so we don't know how it would have turned out. But we know how it started, and the start was promising. ${ }^{99}$

Enterprise leasing involved a contract between the state, as enterprise owner, and the enterprise or its labor collective. The lease contract promised the enterprise greater freedom to make investment and operating decisions, pay higher wages, and retain profits, and the potential to eventually buy ownership of the enterprise from the state-all conditioned on the enterprise producing profits that could be reinvested, used to pay higher wages, or saved toward an eventual buyout.

This scheme created complex but promising incentives and informationrevelation mechanisms. The incentives were similar to those created by leveraged buyouts (an analogy that the privatizers missed). Saved profits were the only funds that could be used for an eventual buyout, so there was a powerful incentive to run the firm efficiently and not to squander profits through higher wages. Conversely, managers that didn't generate (and then save)

\footnotetext{
99 We thank David Ellerman for calling to our attention the potential promise of enterprise leasing as a strategy for staged privatization. Our discussion of enterprise leasing relies primarily on Anna Tarassova's personal knowledge of enterprise leasing in the Moscow region during 1991-1992. For discussions that convey the reformers' antipathy to a program that they saw as half-a-loaf, see, e.g., ROMAN FRYdman, ANDRZEJ RAPACZYNSKi \& JOHN S. EARle, The Privatization Process in Russia, Ukraine AND THE BAltic States 20-22, 63-64 (1993); Aslund (1995), supra note 9, at 225. Ellerman discusses leasing as one form of privatization in David P. Ellerman, Management and Employee Buy-Outs as a Technique of Privatization: Overview, in MANAGEMENT And Employee Buy-Outs as a Technique of Privatization 31, $42-49$ (David P. Ellerman ed. 1993).
} 
enough profits to buy their own firm faced the risk that the state would replace them or sell the firm to outside owners.

The firm's accounts were open to its workers, who could therefore watch the managers. The workers had incentives to monitor the managers, lest the managers pay high salaries to themselves or skim profits. The workers could police self-dealing by complaining through the existing administrative chain of command. Managers, in turn, knew that they could be fired or jailed, or privatization could be withheld, if they ran the enterprise crookedly.

Privatization, then, would be available to those managers who proved their skill by earning profits and proved their honesty by not self-dealing. A managerial culture of honesty would be reinforced. The state, meanwhile, could collect a fraction of the reported profits as taxes. Managers who hid profits would also deprive themselves of the chance for a future buyout. And the state would have a strong incentive to honor the privatization promise when the time came. Privatization would raise revenue today while still promising tax revenue down the road. With a respectable tax base in place and privatization revenue also flowing in, the government would have been less inclined to turn to draconian tax rules in a desperate attempt to raise revenue. Slower privatization of large enterprises would also have given Russia time to develop a better infrastructure to police self-dealing when full privatization occurred.

The early returns from enterprise leasing were positive. It began in 1990, based on an April 1989 decree and a November 1989 law, ${ }^{100}$ and soon proved highly popular with managers and workers. Enterprises that entered the leasing program — self-selected to be sure—often did well. By early 1992, about 9,500 leased enterprises accounted for $8 \%$ of total Russian employment and $13 \%$ of industrial production. The privatizers then shut down the leasing programs, lest too many profitable firms choose leasing and be unavailable to be privatized.

Some nuances of the choice between staged and immediate privatization: First, some firms could become profitable only under new management. Enterprise leasing wouldn't directly lead to replacement of the old managers. But mass privatization as actually carried out, with control given to workers and managers, also produced only limited managerial turnover. The turnover that occurred wasn't always for the better; sometimes bad owners ousted or coopted honest managers. Moreover, with leasing, the state retained the power to install new managers or to sell unsuccessful enterprises to new owners.

\footnotetext{
100 See Decree of the Presidium of the Supreme Soviet of the USSR on Lease and Lease Relations in the USSR (Apr. 1989) (on file with authors); Fundamentals of Legislation of the USSR and the Union Republics on Lease (Nov. 1989) (on file with authors).
} 
Second, enterprise leasing won't work for nonviable enterprises. For these enterprises, the managers' best option will be to skim what they can while they can. But for these enterprises, privatization only accelerated the plunder by loosening bureaucratic controls on theft from state-owned enterprises. The government could more usefully have retained ownership of nonviable enterprises; not subsidized them further, and ideally supervised their liquidation.

Third, for Russia's huge natural resources and utility companies, leasing would have openly conveyed too much wealth to a few lucky managers to be politically feasible. Honest privatization auctions might have been preferable. But even for these enterprises, leasing would likely have been better than the dirty privatization that actually took place.

It's ironic that the Russian Communists of a decade ago, knowing that central planning was a dead end but not fully trusting markets either, likely built through enterprise leasing a better means to manage privatization than the privatize-now approach that Western advisors later promoted and Russian reformers enthusiastically followed. The Russians who blame Western advice for destroying their economy are not entirely wrong.

\section{Other Approaches to Staged Privatization}

Enterprise leasing is only one example of a staged privatization strategy. We discuss below several other approaches to privatization that are consistent with this overall approach.

Cash Auctions. Enterprise leasing is one way to sell enterprises for cash-where the current managers are the only permitted bidders and can pay only with the firm's own accumulated profits. Another way is cash auctions, designed to produce concentrated ownership. A realistic reservation price can segregate viable from nonviable firms, and ensure that insiders don't steal viable firms for a small fraction of true value. Firms for which no one bids the reservation price can be left in state hands, where controls on theft are likely to be stronger. The government can still give their managers incentives to build value by promising to sell their enterprise if its prospects improve, as well as incentives to pursue an orderly liquidation if that is the best alternative.

Russians had enough wealth to make cash auctions viable. At the start of the 1990s, they held about $\$ 100$ billion in savings accounts. The government froze these savings accounts and then inflated the currency, wiping out almost all of their value before they were unfrozen. Once the savings were gone, only crooks and the nomenklatura had the money to buy large enterprises. But cash auctions were feasible ex ante. 
Privatizing Leveraged Companies. Russia privatized companies free of debts to the government. Having firms issue debt to the government as part of privatization could have ensured a realistic minimum price when the companies were sold in cash auctions, because the government's net receipt would be the payment for the equity plus the present value of the debt. By reducing the firm's equity value, it would reduce the amount that the managers could expropriate from minority shareholders. And, if the government were willing to promptly seize and resell firms that defaulted on their debt payments, this would give managers incentives to generate enough cash to make those payments. ${ }^{101}$

Two caveats: First, selling leveraged companies is a form of seller-financing that enables the buyers to leverage their limited cash. That's valuable as an antidote to limited citizen funds, but also dangerous, because leverage creates asset-stripping incentives not too dissimilar from partial equity ownership. So leverage makes sense only for clearly viable firms, and the debt should be limited to a moderate percentage of firm value. Second, either control must automatically revert to the state if the debt isn't paid, ${ }^{102}$ or the government must have both the means and the will to quickly seize companies that don't pay their debts (the Russian government lacked the will for tax debts), or the strategy will collapse.

Selling Minority Stakes to Foreign Firms. For Russia's very large natural resources companies, domestic sales for cash weren't feasible. There wasn't enough cash around to pay more than a fraction of their value, and the largest cash hoards were often obtained in dubious ways. Selling controlling stakes to foreigners was a political nonstarter. But it might have been politically possible to sell to a foreign firm a significant minority stake in, say, a government-owned oil company, with the expectation that the foreign firm would manage the company in the near term, would coinvest in new projects, and the government would sell its remaining stake through a public offering a few years hence, once the Russian securities market had developed enough to make that a viable option. ${ }^{103}$

At the same time, foreign ownership is no panacea. The wrong foreigners can strip assets too. A corrupt government that can't conduct honest auctions

\footnotetext{
${ }^{101}$ This alternative was suggested to us by Dale Gray.

102 For example, upon payment default, the debt could automatically gain voting rights or convert into voting common stock.

${ }^{103}$ This alternative was suggested to us by Janos Kornai.
} 
or control self-dealing isn't likely to do a good job of screening investors, domestic or foreign.

\section{E. The Political Consequences of Dirty Privatization}

Russians themselves do not distinguish sharply between voucher privatization (in which most received worthless shares) and the corrupt sales of the largest enterprises. Both have led to popular distrust of privatization and a market economy. This distrust has already slowed other market reforms and will affect future reforms for decades to come. That's a heavy price to pay for the uncertain economic benefits of fast privatization.

Even if insiders would loot privatized and state-owned firms equally, the political consequences are very different if the theft occurs within government ownership, rather than after privatization. In the former case, the public associates managers' theft of assets with continued state ownership. The political case for eventual privatization becomes stronger and is coupled with political pressure to control self-dealing. In the latter case, the political case for market reforms is undermined, as the public associates privatization with theft of company assets, and company insiders become potent opponents of efforts to control them.

An important political goal of voucher privatization was to build popular support for privatization by distributing share ownership broadly. What irony that the exact opposite happened! Conversely, staged privatization, starting with successful firms, could have given privatization a good name, encouraging future reform efforts. ${ }^{104}$

In addition, one hoped-for consequence of privatization was faster restructuring of major enterprises. Restructuring through new management or new investment was the exception. But restructuring through layoffs, wage arrears, and shedding of social obligations to maintain housing, kindergartens, medical clinics and the like was common.

The shedding of excess costs was inevitable. It might have been politically acceptable if the government had provided the social services that enterprises were shedding, plus some unemployment, retraining, and relocation benefits, especially in company towns where new jobs were scarce. The social consequences would have been milder if the business climate had been friendlier, so that more laid off workers could land jobs at newly created firms.

${ }^{104}$ Cf. Vincent Benziger, The Chinese Wisely Realized that They Did Not Know What They Were Doing, Transition, July-Aug. 1996, at 6, 7 (in China, "small reforms, aimed at relatively easy problems, led to economic expansion, which, in turn, led to increased political support for further reform"). 
Without these ameliorating factors, shedding of social obligations led to a large increase in seriously poor people, a sharp increase in death rates, and political unhappiness with market reforms.

The privatizers sometimes offer a political defense of the corrupt sales of Russia's major firms: The kleptocrats used their wealth and media outlets to buy Yeltsin's reelection as President in 1996. Otherwise, the Communists would have returned to power. We aren't persuaded by this "better crooks than Communists" argument. First, the poisonous mix of corruption, dirty privatization, rampant self-dealing, and Mafia-government ties was a major reason why Yeltsin was desperately unpopular and hence a Communist victory was a serious risk. Better policies might have let Yeltsin (or another reform or center candidate) win easily. Second, by 1999, as it became apparent that the kleptocrats virtually owned the Kremlin, it was no longer so clear that Zyuganov would have been a worse leader than a sick, ineffectual, corruption-tolerating Yeltsin.

\section{F. Toward A Friendlier Business Climate}

The final and perhaps most challenging part of our counterfactual involves creating a friendlier overall business climate. Creating a friendly business climate is a complex task; we list here only a few politically viable steps. But here are several plausible steps. Our goal is to suggest some steps that could have improved the business climate if given high priority.

Political attention is a scarce resource. The reformers focused on rapid large-firm privatization, and thus foreclosed the opportunity to accomplish much along other lines.

One step would have been to waive enterprise-level income taxes on businesses below a certain size, such as 1000 employees. The actual confiscatory taxes that Russia levies are hugely counterproductive. They raise negligible revenue, promote corruption, drive small businesses underground and sometimes out of business, and force businesses to hide their profits (which promotes skimming).

Even rich countries have little success collecting income taxes from small businesses. The United States recently gave up and now allows non-public firms to pass through all profits and losses to their owners, without firm-level income tax. If the United States can't collect these taxes, Russia would have done better not to try. Eliminating income taxes on small businesses has an obvious constituency and would have been politically feasible if tried.

A sec ond critical step would have been to attack corruption and organized crime. If an aggressive attack on corruption had been a top priority for internal reformers and a key condition for outside financial aid, the attack might have 
been launched and would likely have been partly successful. Such an effort is harder today because corruption is more deeply entrenched and many privatized businesses support the corrupt status quo. The political viability of an attack on corruption and the Mafia is not in doubt, only the political will to carry it out.

An attack on bureaucratic interference and on the sheer size of the bureaucracy would have helped. So would privatization of urban land. Local governments often use their control of land to limit new entry in many markets.

\section{INSIDER SELF-DEALING IN THE CZECH REPUBLIC}

The Czech Republic offers an interesting comparison to Russia that can help isolate which aspects of the Russian experience with rapid mass privatization were unique to Russia, and which may reflect deeper problems that arise when privatization precedes development of legal and institutional controls on self-dealing.

The Czech Republic was the first formerly Communist country to plunge into voucher privatization, through auctions that took place in two stages, in 1991-1992 and 1993-1994. By 1994, over 2,000 state-owned firms had been privatized through the voucher program; around 500 voucher investment funds had emerged to collect vouchers and invest in privatized firms; most of Czech industry was in private hands; competing stock markets had emerged; and the Czech economy was growing briskly, with rapid formation of new businesses and low unemployment. As late as 1996, the Czech Republic seemed to be "the success story of Eastern European mass privatization." 105

Today, no one is so sanguine. The early Czech stock market success was replaced by a scramble for control of privatized enterprises; stock prices that collapse once control is attained; and insider looting of many privatized companies and voucher investment funds. The Czechs invented their own term-tunneling - for the widespread practice of selling a company's products at below-market prices to an intermediary owned by the company's managers, to be resold at market price. As a result, the Czech Republic plunged into recession in 1997 and 1998, while neighboring Poland and Hungary, which were slower to privatize large firms but built better controls on self-dealing, continued to expand briskly.

\section{A. The Czech Experience with Tunneling}

\footnotetext{
105 John C. Coffee, Jr., Institutional Investors in Transitional Economies: Lessons from the Czech Experience, in 1 CORPORATE GOVERNANCE IN CENTRAL EUROPE AND Russia: BANKS, FundS, AND FOREIGN INVESTORS 111, 111 (Roman Frydman, Cheryl W. Gray \& Andrzej Rapaczynski eds., 1996).
} 
Czech mass privatization sparked the emergence of voucher investment funds, which collected vouchers from citizens and invested in the companies that were being privatized. The voucher investment funds often took sizeable stakes in a limited number of firms, enough to give them influence and sometimes control. This seemed at first to be encourage restructuring. When holdover management couldn't make the transition to a market economy, the funds could install new managers. There was, however, concern that the notyet-privatized Czech banks, who owned some of the largest investment funds, would use their equity stakes to cement lending relationships, rather than to promote restructuring. ${ }^{106}$

The bank-run investment funds indeed didn't generate much restructuring. But that was the good news. A retrospective analysis by the Czech Ministry of Finance found a negative correlation between post-privatization firm performance and the percentage of shares held by non-bank voucher investment funds. The principal reason was that the voucher investment funds used their influence not to restructure firms, but to tunnel away the firms' profits. ${ }^{107}$

As scandals proliferated, foreign investors withdrew-net foreign direct and portfolio investment dropped from \$103 million in 1995 to \$57 million in 1996 and turned negative in 1997. And the Czech stock market imploded. Total listed companies dropped from a peak of around 1700 in 1994 to 283 at year-end 1998. The number of companies on the "main exchange," the only one with significant liquidity, dropped from 62 in 1995 to 10 in 1998. And there has not yet been a single Czech IPO.

\footnotetext{
106 Our discussion of the Czech experience relies on the personal knowledge of Bernard Black and our research assistant, Brian Fonville, and on Coffee (1996), supra note 105; John C. Coffee, Jr., Inventing a Corporate Monitor for Transitional Economies: The Uncertain Lessons from the Czech and Polish Experiences, in Comparative Corporate Governance: The State of the ART AND EMERging Research 68 (Klaus Hopt, Hideki Kanda, Mark Roe, Eddy Wymeersch \& Stefan Prigge eds. 1998); John C. Coffee, Jr., Privatization and Corporate Governance: The Lessons from Securities Market Failure, 25 J. CORP. L. 1 (1999); Czech Ministry of Finance, Current Aspects of the Czech Capital Market (informally circulated report, 1997) (on file with authors); Raj M. Desai, Reformed Banks and Corporate Governance in the Czech Republic, 1991-1996, 37 POST-SoviET GeOgRAPHY \& ECON. 463 (1996); Andrew Weiss \& Georgiy Nikitin, Performance of Czech Companies by Ownership Structure (working paper 1998); ORGANIZATION FOR ECONOMIC Cooperation and Development, OeCD Economic Surveys 1997-1998: CZech Republic (1998) and OECD ECONOMIC SuRveys 1999-2000: CZECH RePublic (2000); Johnson \& Shleifer (1999), supra note 7.

${ }^{107}$ Cf. Weiss \& Nikitin (1998), supra note 106 (finding no correlation between performance and ownership by either bank-run or non-bank investment funds).
} 
The minimal regulation of investment funds, companies, and securities markets was by design. The Czech government was dominated by fervent free-marketeers who believed that market participants would largely regulate themselves. ${ }^{108}$ They were simply wrong. The scams that quickly developed offer a tutorial in the ways that fraudsters can extract value from both companies and investment funds. A Czech Ministry of Finance report identified fifteen common techniques: ${ }^{109}$

- the interconnection of severalcompanies - especially investment companies, investment funds and securities dealers, pension funds, banks and other companies. These interconnections are informal, hard to identify, and utilize puppets.

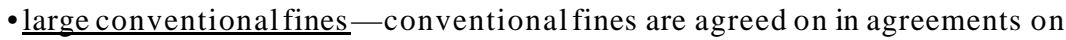
securities transfer, the amount often being a multiple of the value of the agreed deal .... Simultaneously, failure to comply with conditions is ensured by the above interconnection of persons in the contracting parties.

- purchases of worthless shares - persons controlling investment companies or investment funds found a normal joint-stock company, whose shares are based on worthless property (e.g. receivables, know-how) and the n these shares are purchased [by the] investment fund or unit trust.

- concluding unfavourable options and futures contracts - such agreements do not cover the [market price] risks associated with ... [the] securities held by the investment fund or unit trust [that are subject to the option or futures contract]....

- transfer of advances for the purchaseof securities - the investment company or investment fund transfers [funds to] ... a securities dealer; this cash is not subject to payment of interest by the dealer . . . ; the dealer makes use of this money for dealing in his own name and ... [may have] negligible assets ... .

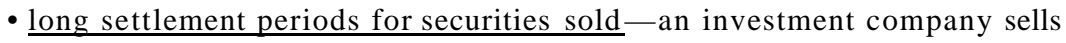
securities. ... and sets a [very] long settlement period.... In the meantime the company owing the money declares bankruptcy and is liquidated.

108 See Vaclav Klaus, Renaissance: The Rebirth of Liberty in the Heart of Europe (1997) (Klaus was Czech Prime Minister during mass privatization).

${ }^{109}$ Czech Ministry of Finance (1997), supra note 106, at 4-9. 


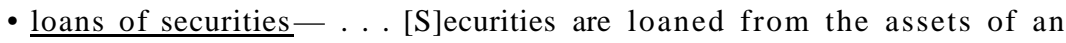
investment fund or a unit trust without any guarantees and even without any payment for the loan.

- poorly drawn-up agreements on the transfer of securities - the agreements do not cover basic obligations, such as the date of supply of the security [or the] date of settlement of advances for the purchase of the securities....

- irrational movements of securities - there are entire chains of trades in a single type of security; over a few days or weeks or even months, the respective security is owned by a whole series of companies and then returns to the fund at an entirely different price than that when it left. . .

- trading in securities at ridiculous prices - such operations can be carried out especially because there is no objectively determinable price for most securities as the price-creating function of the public market fails to operate. ... [Czech law] prohibits funds fromloaning money from their assets to other (i.e.third) parties. Funds evade this restriction by concluding an agreement on the sale of securities from their assets to some other legal entity, usually an associated one, at a very low price. A verbal agreement is then made that this associated person will sell the securities back to the fund after a certain period of time, again at a very low price. . .

- disadvantageous purchases and sales of securities- - . . [funds may purchase new issues of a company's shares] for large sums while the se shares can be purchased on the market at much lower prices....

- trading by management on its own account-these practices ... [are] associated with the misuse of confidential information, obtained on Boards or Directors of joint-stock companies, whose shares are part of the assets of the fund; this information is supplied to the [fund's] management, employees, or relatives, or the [company's] shares are sold to such persons at low prices...

- concentration of considerable amounts of cash in the accounts of investment funds or unit trusts in banks. This method formed the basis for subsequent "tunneling" into unit trusts managed by the CS Fund, ... [which] gradually sold securities from the assets of the unit trustand when the entire assets were transferred in the form of deposits to a bank, the deposits were withdrawn and transferred to an account abroad. ...

- failure to comply with limits for restricting and spreading risks - [Czech law] sets forth limits for holding securities [of a single issuer] in relation to the total volume of assets owned by an investment fund or unit trust . . . Cases have been registered in which investment funds... exceeded the limits for restricting and spreading risks.... Simultaneously, the [companies] whose 
shares were owned by the funds encountered difficulties, . . . their shares fell to zero value and the investment funds often suffered considerable losses. .

- "tunneling" into companies is a frequent phenomenon-current "corporate raiders" have discovered a risk-free method of removing money from companies. This method consists of holding a general meeting of shareholders, in which the "raiders" have a voting majority; this meeting passes a decision on a transaction involving company property ... and the Board of Directors of the company then carries out this operation, with consequent damage to the company. No (minority) shareholder can blame the Board of Directors of the company for this operation as it is bound by the decision of the general meeting ....

These ways of "handling" the assets of investment funds and unit trusts are combined in practice and are very difficult to demonstrate and penalize.

The ardent free-marketeers who resisted calls to regulate Czech capital markets may have been sincere in the beginning. But by the late 1990s, many had been bought, as company managers turned to bribery to ward off regulation or prosecution. The Klaus government fiercely resisted calls for an anticorruption probe; Klaus himself simply denied (against all evidence) that the Czech Republic had a problem with corruption or tunneling. ${ }^{110}$

The Czech Republic, unlike Russia, responded to the scandals. A corruption scandal brought down the Klaus government in 1997; a Securities Commission, which Klaus had long opposed, was installed the same year; the new government launched an anti-corruption drive which has been at least a partial success; and legal controls on investment funds and majority shareholders were tightened. Much remains to be done, but these efforts give hope of improved long-term performance. Still, for now, the government is shutting the barn door after many valuable horses have been removed and much harm has been done to the economy.

\section{B. Comparing Russia and the Czech Republic}

The Czech Republic privatized without controls on self-dealing, but otherwise provided a reasonably good business environment. It had been

110 See Peggy Simpson, Some Confess Mistakes in Velvet Revolt, but not Czech's Klaus, WARSAW Bus. J., Oct. 25, 1999. On the Klaus government's growing corruption, see Andrew Schwartz, The Best Laid Plan: Privatization and Neo-Liberalism in the Czech Republic (1999) (Ph.D. dissertation, Univ. of Calif. (Berkeley)) (on file with authors). 
Communist for only about forty years, not seventy-five like Russia; its economy wasn't as thoroughly distorted by central planning; memories of how to run a private business survived; it was close to export markets in Western Europe; and many Czech firms faced strong import competition.

That not-so-bad environment was sufficient to nourish self-dealing. One central reason: The shares of a mass-privatized company were worth more to crooks, who would use $50 \%$ control to extract $100 \%$ of value, than to honest owners who would run the company for the benefit of all shareholders. At the same time, the Czech Republic's friendlier business climate meant that for insiders, looting was sometimes less attractive than building long-term value or selling to someone else who would do so. In Russia, theft of company assets became the norm; in the Czech Republic, it merely became distressingly common.

Still, the many Czech cases where insiders skimmed from viable enterprises, instead of restructuring them, demonstrate-as the Russia example alone cannot-that strong controls on self-dealing are a necessary precondition for successful large-firm privatization. In neither country did many entrepreneurs both run the business to maximize long-term profit and skim profits in the near term. In the Czech Republic, that may reflect looters' assigning a low weight to the firm's long-term value, given the risk that a future government will investigate their near-term theft.

The Klaus government turned, between 1992 and 1997, from a collection of apparently honest free-market ideologues into corrupt opponents of restrictions on tunneling. Proposed regulations and proposed indictments of the tunnelers were routinely quashed. A (second hand, so unverifiable) story from a Finance Ministry official : The Ministry staff's record in getting Klaus and other senior officials to approve criminal cases against tunnelers was $0 / 26$. In the Czech Republic, as in Russia, privatization without controls on self-dealing fostered corruption, as the self-dealers bought government officials, both to permit continued self-dealing and to ward off prosecution.

Growth in labor productivity offers a good measure of a country's overall success in privatization and transition policy. Table III shows the striking contrasts between Hungary and Poland, which stumbled into something resembling our staged privatization/institution building proposal; the Czech Republic, which had the capacity to do likewise but pursued mass privatization instead; and Russia, which started from a worse place and pursued mass privatization. 
Table III

Labor Productivity in Selected Transition Countries, 1989-1998

$\begin{array}{lc}\text { Country } & \text { Change in Labor Productivity (\%) } \\ \text { Hungary } & 36 \% \\ \text { Poland } & 29 \% \\ \text { Czech Republic } & 6 \% \\ \text { Russia } & ! 33 \%\end{array}$

Source: ECONOMIC COMM'N FOR EUR., ECONOMIC SURVEY OF EUROPE 1999 NO. 3 (1999)

\section{The Special Case of Voucher Investment Funds}

In both Russia and the Czech Republic, the privatizers hoped that voucher investment funds would become strong outside owners, who could replace bad managers and force restructuring of enterprises. That sometimes happened, but more often, the voucher investment funds were part of the problem, not the solution. Too often, they looted the companies they invested in and were looted themselves. Roughly a quarter of Czech investment funds were looted so thoroughly that they went bankrupt; another quarter were converted into unregulated holding companies, with likely adverse consequences for their minority investors. In Russia, too, many investment funds simply disappeared, and their assets were never traced.

Our theoretical analysis in Part III.A of an amoral controller's choice between value creation and self-dealing can help to explain why. First, fund controllers hold only a modest fraction of the cash flow rights (through their management fee). Second, a value creating strategy is most likely to maximize the controller's private value for a company with strong growth prospects. For voucher investment funds, growth prospects are limited. They receive a oneshot infusion of capital at the time of voucher privatization, that won't be replicated through private investment for a long time, if ever. ${ }^{111}$ This virtually ensures that if self-dealing isn't policed, an amoral controller will be better off stealing the fund's value than keeping a partial claim on that value through management fees. All the more so if the fund can first tunnel into operating companies that it controls. ${ }^{112}$

\footnotetext{
111 In Russia, the inability of voucher investment funds to attract new investment was guaranteed by fund-level taxation that proved politically impossible to remove.

112 Thus, we disagree with arguments that stronger oversight by voucher investment funds could have ameliorated Russia's problems with manager control of privatized firms. See Raj M. Desai \&
} 
[VOL. 52:XXX

The incentive to loot created by the separation of ownership and control at the fund level is exacerbated at the level of the companies that the fund invests in. Investment fund control of operating companies is a pyramid structure under another name. Suppose that the fund manager collects an annual fee equal to $2 \%$ of assets. That might represent, in present value, a claim on $15 \%$ of the fund's value. If the fund owns $20 \%$ of an operating company, the fund manager's claim on the operating company's value is a scant $15 \% \cdot 20 \%=3 \%$. The smaller that percentage claim, the more attractive looting becomes. ${ }^{113}$

Just as crooks can outbid honest owners for control of operating companies, making dispersed ownership unstable if self-dealing is easy, so too for investment funds. An example: The Austrian bank Creditanstalt sponsored a major Czech investment fund. But Czech citizens who though they were safe entrusting funds to Creditanstalt soon discovered otherwise. Motoinvest bought $11 \%$ of the fund's shares in the market, called a special shareholder meeting, replaced Creditanstalt as manager, and proceeded to loot the fund. ${ }^{114}$

It also was never realistic to expect even honest fund managers to devote much attention to restructuring portfolio firms. The same pyramid structure that creates incentives to loot creates disincentives to pursue restructuring: the fund manager will realize only a small fraction of the resulting gains in company value. Nor were voucher funds a source of the new capital that many firms needed. ${ }^{115}$

\section{A Czech Counterfactual: Mass Privatization with Institution Building}

The Czech Republic's chose to privatize in a hurry, and not to build institutions to control self-dealing. That hands-off policy gave the tunnelers a six-year head start; the regulators have not yet caught up. A difficult counterfactual: What if the Czech Republic had vigorously pursued both mass privatization and institution building?

\footnotetext{
Itzhak Goldberg, The Vicious Circles of Control: Regional Governments and Insiders in Privatized Russian Enterprises (working paper 1999), available in Social Sciences Research Network at <http://papers.ssrn.com/paper.taf?abstract_id=190570〉.

${ }^{113}$ See David Ellerman, Lessons from Voucher Privatization (working paper 2000).

114 See Bruce Kogut \& Andrew Spicer, Institutional Technology and the Chains of Trust: Capital Markets and Privatization in Russia and the Czech Republic (working paper 1999) <http://eres.bus.umich.edu/docs/workpap-dav/wp291.doc〉.

115 See Bernard Black, Shareholder Passivity Reexamined, 89 Mich. L. Rev. 520, 575-84 (1990) (modeling money managers' incentives to monitor); Ellerman (1999), supra note 2 (discussing reasons why voucher funds weren't a promising source of restructuring effort).
} 
Our own judgment: The tunnelers would still have largely outrun the regulators. In the early 1990s, Czech regulators and prosecutors were completely inexperienced in how to regulate capital markets or control selfdealing. Czech courts were and remain overloaded and unsophisticated. Neither could deal with the misdeeds of the controllers of thousands of enterprises and voucher funds. Mass privatization, even with coupled with an immediate effort to build these and other needed institutions, would have given the crooks a critical head start. The crooks would then have used the funds generated by that head start to compromise the regulators, ensuring that the government wouldn't run too fast to catch up. ${ }^{116}$

\section{IMPLICATIONS FOR FUTURE PRIVATIZATION EFFORTS}

Mass privatization was motivated, in important respects, by faith. As Andrei Shleifer and Robert Vishny, key Western advisers on Russian privatization, wrote as recently as 1998:

We believe that managerial discretion problems are usually minor relative to political discretion problems. Privatization works because it controls political discretion. ${ }^{117}$

For Russia, we once shared that belief. ${ }^{118}$ So did the Western advisors who pushed the Czech Republic, Russia, and many other countries to plunge ahead with mass privatization. But they and we were wrong. The faith that any private owner was better than state ownership rested on an unexamined premise-that a country has the will and infrastructure to control managerial discretion manifested through overt self-dealing. If the state cannot control this form of white-collar crime, then the balance between the problems of managerial discretion and political discretion is uncertain.

We have learned that Western-style capitalism is more fragile than we thought. It will not emerge — certainly not quickly, perhaps not at all—if seeds are simply scattered widely through mass privatization, to grow in the thin soil of an institutionally impoverished country. Instead, the institutions that control theft in its myriad forms, especially self-dealing by managers and controlling shareholders, are an essential fertilizer.

\footnotetext{
116 Accord, Schwartz (1999), supra note 110, at 209, see also Kogut \& Spicer (1999), supra note 114

${ }^{117}$ SHLEIFER \& ViSHNY(1998), supra note 50, at 150 (emphasis added).

${ }^{118}$ Black and Kraakman did, anyway. Tarassova disclaims ever having done so.
} 
The task of creating fertile soil in which privatized companies can take root is not a simple one. We don't yet know how strong the infrastructure must be before large-firm privatization is likely to significantly promote economic growth. Moreover, many of the necessary institutions can develop only as the market develops. The securities commission and criminal prosecutors need fraud to practice on, if they are to become skilled at combating fraud. Accountants, investment bankers, and other reputational intermediaries also learn from their mistakes-from the frauds they didn't catch.

What we do know is discouraging. The necessary tasks can't be completed quickly. Controlling corruption is essential, but not enough. Ironically, the countries that have made the worst hash of managing their state-owned enterprises are least likely to possess the institutions that would let them gain from rapidly privatizing large firms. ${ }^{119}$

\section{A. Steps Toward Successful Large-Firm Privatization}

What then should a country with weak institutions do, with its not-yetprivatized firms or its already privatized firms? For not-yet-privatized firms, the counterfactual that we offered in Part IV, including attacking corruption, building institutions to control self-dealing, staged privatization, and a privatization plan that produces concentrated rather than dispersed ownership where feasible, offers a guide on how one might proceed.

For both already privatized and not-yet-privatized firms, Russia needs a serious, top-down effort to control corruption, organized crime, and self-dealing; adopt a rational tax system; reduce the broad administrative discretion that invites corruption; shrink the bloated bureaucracy; enforce existing rules that limit self-dealing; remove the principal loopholes in those rules; and improve financial reporting by major firms (which isn't feasible until the tax system permits firms to report results honestly). The relevant "top" could be a central government or a regional government. No one of these steps is sufficient by itself, but each will help and progress on any one can reinforce progress on others.

No sensible person could be against these changes, and many Russians understand their importance. But none is yet at the top of the Russian government's agenda. They need to be. Otherwise, Russia risks going the way of Nigeria-another oil-rich country whose government is thoroughly corrupt and its population impoverished, while a favored few skim billions into offshore accounts. There's hope that Russia's new President, Vladimir Putin, will mount

119 Black (2000), supra note 6, discusses the institutions that underlie strong securities markets. 
a serious attack on corruption, but as yet no solid evidence that he will do so. His public anti-corruption, anti-kleptocrat rhetoric hasn't thus far been matched by his behind-the-scenes actions. ${ }^{120}$

\section{B. The Case for Selective Renationalization and Reprivatization}

For already privatized firms with bad owners, there are no easy solutions, but here is one unconventional proposal. Western advisors are reluctant to propose renationalization as a remedy, no matter how corrupt the initial privatization. In contrast, we see possible merit in selective renationalization, followed promptly by reprivatization. When - and only when - the government develops the will and ability to reprivatize promptly and honestly, it could make sense to both prosecute corporate thieves and renationalize companies that were, for all practical purposes, stolen.

The case for renationalization and reprivatization will depend on companyspecific misdeeds that justify this remedy. Here are two examples. Suppose that Mikhail Khodorkovski transfers all value from Yukos and its subsidiaries to shadowy offshore companies. Renationalization and reprivatization would harm no one but Khodorkovski and his accomplices, could produce better owners who will pay workers, pay taxes, and invest in Yukos' oil fields, and raise serious revenue for the government. A reprivatization auction that raised $20 \%$ of the value of a comparably sized Western firm could raise $\$ 35$ billion, which exceeds the government's current annual tax revenue. Similarly, renationalization of Zarubezhtsvetmet would harm only its current crooked owners, benefit the Erdenet copper mine and the entire country of Mongolia, and permit Russia to earn the revenue from privatization that it should have earned the first time.

The appropriate analogy is to thieves who steal government property. The government's appropriate response is put the thieves in jail (unless they flee the country first) and seize and resell their ill-gotten property. As long as the government seizes property only from thieves, we shouldn't worry too much that honest owners will be scared off from investing, lest the government treat them the same way.

Indeed, the anti-renationalization advice now proffered by the multilateral institutions is internally inconsistent. The IMF and the World Bank are encouraging governments around the world to seize insolvent financial institutions (often made so by bad loans to insiders). They have missed the

120 See David Hoffman, Putin's Actions Seem to Belie Promises on Tycoons, WASH. Post, May 7, 2000, at A21. 
analogy between seizing a financial institution that has been stripped by insiders and seizing a nonfinancial institution that has been stripped by insiders.

We propose renationalization plus prompt reprivatization, when and only when the government can do a better job both in reprivatizing and in controlling insider self-dealing. ${ }^{121}$ We have no opinion on whether renationalization without privatization could make sense. That depends on whether a Russian government that can't conduct honest auctions of major companies can nonetheless run these companies better than their current owners. That is a tough choice between two bad owners. Moreover, reprivatization auctions make sense only if they will be more honest than the initial privatization. In Russia today, there is not yet a basis for those beliefs.

Renationalization has costs. It can cause bad owners to accelerate the plundering of the enterprises that they control. If it extends beyond clear cases of theft, it can lead managers who might otherwise manage firms with at least one eye toward long-term value to plunder instead. But if limited to clear cases of theft (of which Russia has no shortage), and if accompanied by criminal prosecution of the crooks, renationalization can also convey an important message to managers about the limits of acceptable behavior and the long-term risk from plundering. In the end, the appropriate deterrent to theft cannot be to turn a blind eye to all crooks, for fear that prosecuting some will cause others to steal faster before their turn comes.

\section{Strengthening Product Market Discipline}

Competition and trade policy are essential accompaniments to privatization. The more competitive the market, the greater the pressure to improve operational efficiency, the fewer the rents to be skimmed, and the shorter the time period for which skimming can be sustained. ${ }^{122}$ Discussion of Russia's competition and trade policies is beyond the scope of this article, but Russia has a long way to go. The European Bank for Reconstruction and Development

121 For a proposal that the Russian government swap tax obligations for additional company shares, which it will then promptly sell to investors, see Desai \& Goldberg (1999), supra note 112. In our judgment, Desai \& Goldberg don't sufficiently question whether the Russian government's auctions of shares that it receives in exchange for tax obligations would be more honest or produce better owners than recent past auctions.

122 On the correlation between competition policy and outcomes from privatization, see John Nellis, Competition and Privatization: Ownership Should Not Matter-But It Does, 4 REVISTA DO Instituto BRASILEIRO DE Estudos DAS RElACOES DE CONCORRENCIA E DE CONSUMO 211 (1997); Pankaj Tandon, The Efficiency of Privatized Firms: Evidence and Implications (Boston Univ. working paper 1994) (on file with authors). 
rates Russia as $2+$ on a 1-5 scale for competition policy. ${ }^{123}$ And Russia's trade policy has been moving in the wrong direction-toward higher customs duties and tighter restrictions on oil exports.

Competition policy should make it easy for new firms to challenge existing monopolists; trade policy should make it possible for imports to challenge domestic products. The state monopoly over distribution that still exists in much of Russia is especially pernicious, because it blocks competition across a whole range of industries. Just as it helps to install controls on self-dealing by controllers of large firms before or at least together with privatization, lest private firm owners defeat subsequent efforts to install these controls; so too with competition and trade policy, lest private firm owners defeat efforts to reduce their monopoly rents.

\section{How Can the Outside World Help Russia?}

What the world outside Russia can do now to help isn't clear. Decades of foreign aid to corrupt governments show that shoveling money at them doesn't help economic development, and might hurt by financing the society's corrupt elements and imposing a repayment burden (since most aid is in the form of loans). ${ }^{124}$ IMF aid was supposed to buy time for Russia to reform its tax system so it could collect the revenues it needed to balance its budget; instead, aid permitted the existing system to survive a bit longer, by substituting for revenues that the government didn't collect, while its tax reform promises went unkept. Most of the proceeds were apparently siphoned off by kleptocrats and government officials, leaving Russia to choose between the burden of repayment and official default (Russia has thus far mostly chosen the latter).

It might help to promise aid that is conditioned on promises being kept, not merely made. A government that first adopted simple, enforceable tax rules, put a respectable number of corrupt officials in jail, and solved a few of the many murders of politicians and businessmen might be worth trusting to use aid funds to support development or to assist the losers from the switch to a market economy. In the interim, useful steps are scarce and the payoff will be measured in decades. Here are a few modest ideas.

123 European Bank for Reconstruction and Development, Transition Report 1999 (2000), at 24; see also Broadman (2000) supra note 52.

124 See, e.g., The World BANk, ASSESSING AID: What Works, What Doesn't, AND Why (1998); Jonathan Isham \& Daniel Kaufman, The Forgotten Rationale for Policy Reform: The Productivity of Investment Projects, 114 Q.J. ECON. 149 (1999). 
[VOL. 52:XXX

Efforts to support legal reform are worthwhile. Good laws on the books are a background condition that will become important when and if an honest government emerges. Aid that helps Russia to develop enforcement capacity could be highly useful. For example, judges and prosecutors need training to handle complex corporate cases, and the Securities Commission needs all the enforcement resources it can get. Training won't help when prosecutors are called off by politicians, but not every corporate crook has as much political clout as the first-tier kleptocrats.

It could help to fund smart young Russians to study law, business, and accounting in Western countries. Many would stay (benefitting their new home country but not Russia), but some would return, and more would return in a decade or two, by then highly skilled, if opportunities improve. The return of foreign-trained professionals has aided development of other countries, including China, Taiwan, India, and Ireland. It could help Russia too.

A small example: Funding 500 top Russian law students to get Western legal training (in the U.S. and Europe) would cost perhaps $\$ 20,000,000$ per year initially, and less over time if students who took law firm jobs (as most will) had to repay their tuition loans. Many of these lawyers would return to Russia, either immediately or if business conditions improve. In twenty years, Russia would have a pool of 10,000 well-trained lawyers who understand how marketsupporting laws work. Some would become bar leaders, law teachers, senior government officials or political leaders who could help to bring such a system about.

An equally long-run project would be to develop new private Russian law and business schools. Russia's current law schools are far too small to meet its need for business lawyers and are often dominated by Communist-era holdovers. Business schools scarcely exist - the Soviet Union didn't need them.

Foreign pressure aimed at opening Russia's markets to competition could be useful, because strong product market competition can police much self-dealing. But the advice to open markets to imports and foreign investment must be coupled with the advisors' willingness to open their own markets to Russian exports-willingness that has sometimes been absent.

\section{CONCLUSION}

A central economic lesson of the 20th century is the huge difference between well-run, mostly market-centered economies and badly-run, often government-centered economies. That experience demonstrates the boost that good government can give to economic performance, and the difficulty of escaping from a legacy of bad government. 
A central lesson from the past decade is that mass privatization offers no escape from that general lesson. A sufficiently weak government can't build the infrastructure that is needed to control self-dealing and support a complex market economy. Yet without that infrastructure, rapid large-firm privatization won't help the economy much if at all. Initial conditions matter more, institutions matter more, and privatization matters much less, than we though in the early 1990s.

In the artificial world of the Coase Theorem, the manner of privatization wouldn't matter much. Bad initial owners would quickly sell enterprises to good owners, who would build long-term value. In the real world, bad initial owners loot enterprises instead and corrupt the government while they're at it. Call it the triumph of Hayek over Coase-of Hayekian respect for endogenously developed traditions over the abstract promise of Coase-influenced mass privatization schemes. ${ }^{125}$

More generally, mass privatization was part of the shock therapists' effort to destroy the existing structure of state control, quickly and irrevocably. In the political sphere, as Edmund Burke taught us two centuries ago, destructive revolutions often come to bad ends. ${ }^{126}$ That lesson has been relearned many times since (not least in Russia under the Communists). Economic revolutions that destroy existing institutions before new ones can be built are similarly likely to founder, as those without scruples take advantage of the resulting institutional vacuum.

\section{REFERENCES}

Paul S. Adler \& Seok-Woo Kwon, Social Capital: The Good, the Bad, and the Ugly (working paper 1999), available in Social Science Research Network at <http://papers.ssrn.com/paper.taf?abstract_id=186928>.

Alice H. A mSden, JaceK Kochanowicz \& Lance TAYlor, The Market Meets Its MATCH: RESTRUCTURING THE ECONOMIES OF EASTERN EUROPE (1994).

ANDERS A SLUnd, How RuSSIA BECAME A MARKET ECONOMY (1995).

Anders Aslund, Russia's Collapse, FOREIGN AfF. Sept./Oct. 1999, at 64.

Lucian Arye Bebchuk, A Rent-Protection Theory of Corporate Ownership and Control (Nat'l Bureau of Econ. Research Working Paper No. W7203, 1999), available in

\footnotetext{
125 See Kornai (2000), supra note 2, 126 (contrasting the roots of his own work in Hayek and Schumpeter to the "vulgar Coase-ism" of the shock therapists). For Hayek's views, see FRIEDRICH A. HAYek, 1 LAw, Legislation AND Liberty: Rules And Order (1973). For Coase's views about the Coase theorem and what he meant by it, see Ronald H. CoAse, ThE FIRM, THE MARKET, AND THE LAW chs. 5-6 (1988).

126 See Edmund Burke, Reflections on the Revolution IN France (1790) (Thomas H.D. Mahoney ed., Liberal Arts Press 1955).
} 
S o c i a l S c i e n c e R e s e a r c h N e t w o r k a t <http://papers.ssrn.com/papaer.taf?abstract_id=203110>.

Lucian Bebchuk, Reinier Kraakman \& George Triantis, Stock Pyramids, CrossOwnership, and Dual Class Equity: The Creation and Agency Costs of Separating Control from Cash Flow Rights (Olin Ctr. for Law, Econ., and Bus., Harvard Law Sch., Working Paper No. 249 1998), available in Social Science Research Network at <http://papers.ssrn.com/paper.taf?abstract_id=147590>.

Laura Belin, A Year of Discord, in AnNuAl SURVEY of EASTERn Europe AND THE FORMER SOVIET UNION: 1997-THE CHALLENGE OF INTEGRATION, at 276 (Peter Rutland ed. 1998).

Laura Belin, Changes in Editorial Policy and Ownership at Izvestiya, in ANNUAL SURVEY OF EASTERN EUROPE AND THE FORMER SOVIET UNION: 1997-THE CHALLENGE OF INTEGRATION at 291.

Vincent Benziger, The Chinese Wisely Realized that They Did Not Know What They Were Doing, TRANSITION, July-Aug. 1996, at 6.

Matt Bivens \& Jonas Bernstein, The Russia You Never Met (informally circulated English version; Russian version published in DEMOKRATIZATZIYA (1999)) (on file with authors, available without footnotes at <//http://www.wayan.net/journal/russia/feb_22.htm>).

Bernard Black \& Reinier Kraakman, A Self-Enforcing Model of Corporate Law, 109 HARV. L. REV. 1911 (1996).

BERNARD S. BLACK, REINIER KRAAKMAN \& ANNA TARASSOVA, GUIDE TO THE RUSSIAN LAW ON JOINT STOCK COMPANIES (1998).

Bernard S. Black, The Legal and Institutional Preconditions for Strong Securities Markets, 48 UCLA L. REV. (forthcoming 2000), available in Social Science Research Network at <http://papers.ssrn.com/paper.taf?abstract_id=182169>.

Bernard Black, Shareholder Passivity Reexamined, 89 Mich. L. Rev. 520, 575-84 (1990).

Bernard Black, Shareholder Robbery, Russian Style, ISSUE ALERT, Oct. 1998, at 3 (published by Institutional Shareholder Services).

OLIVIER BLANCHARD, THE ECONOMICS OF POST-COMMUNIST TRANSITION (1997).

Joseph R. Blasi, Maya Kroumova \& Douglas Kruse, Kremlin Capitalism: PRIVATIZING THE RUSSIAN ECONOMY (1997).

M AXIM BOYCKO, A NDREI SHLEIFER \& ROBERT ViSHNY, PRIVATIZING RuSSIA (1995).

Maxim Boycko, Andrei Shleifer \& Robert W. Vishny, Voucher Privatization, 35 J. FIN. ECON. 249 (1994).

Elizabeth Brainerd, Winners and Losers in Russia's Economic Transition, 88 AMER ECON. REV. 1094 (1998).

Harry G. Broadman, Reducing Structural Dominance and Entry Barriers in Russian Industry, REV. IND'L ORG. (forthcoming 2000).

J. David Brown \& John Earle, Competition and Firm Performance: Lessons from Russia (working paper 2000), available in Social Science Research Network at <http://papers.ssrn.com/paper.taf?abstract_id=222229>.

EDMUND BURKe, REFleCtions ON THE REVOLUTION IN FRANCE (1790) (Thomas H.D. Mahoney ed., Liberal Arts Press 1955).

RONALD H. COASE, THE FIRM, THE MARKET, AND THE LAW chs. 5-6 (1988). 
John C. Coffee, Jr., Institutional Investors in Transitional Economies: Lessons from the Czech Experience, in 1 CORPORATE GOVERnANCE IN CENTRAL EUROPE AND RuSSIA: BANKS, FUNDS, AND FOREIGN INVESTORS 111 (Roman Frydman, Cheryl W. Gray \& Andrzej Rapaczynski eds., 1996).

John C. Coffee, Jr., Inventing a Corporate Monitor for Transitional Economies: The Uncertain Lessons from the Czech and Polish Experiences, in COMPARATIVE CORPORATE GOVERnANCE: THE STATE OF THE ART AND EMERGING RESEARCH 68 (Klaus Hopt, Hideki Kanda, Mark Roe, Eddy Wymeersch \& Stefan Prigge eds. 1998).

John C. Coffee, Jr., Privatization and Corporate Governance: The Lessons from Securities Market Failure, 25 J. CORP. L. 1 (1999).

Stephen S. Cohen \& Andrew Schwartz, Privatization in the Former Soviet Empire: The Tunnel at the End of the Light, A MER. PROSPECT, Spr. 1993, at 99.

Michael Ian Cragg \& I.J. Alexander Dyck, Management Control and Privatization in the United Kingdom, 30 RAND J. ECON. 475 (1999).

Czech Ministry of Finance, Current Aspects of the Czech Capital Market (informally circulated report, 1997) (on file with authors).

Raj M. Desai, Reformed Banks and Corporate Governance in the Czech Republic, 1991-1996, 37 POST-SOVIET GEOGRAPHY \& ECON. 463 (1996).

Raj M. Desai \& Itzhak Goldberg, The Vicious Circles of Control: Regional Governments and Insiders in Privatized Russian Enterprises (working paper 1999), available in $\mathrm{S}$ o c i a $1 \quad \mathrm{~S}$ c i e n c e s $\mathrm{R}$ e s e a r c h N e t w o r k a $<$ http://papers.ssrn.com/paper.taf?abstract_id=190570>.

Simeon Djankov \& Peter Murrell, Enterprise Restructuring in Transition: A Quantitative Survey (working paper 2000).

David Ellerman, Lessons from Voucher Privatization (working paper 2000).

David P. Ellerman, Management and Employee Buy-Outs as a Technique of Privatization: Overview, in MANAGEMENT AND EMPLOYEE BUY-OUTS AS A TECHNIQUE OF PRIVATIZATION 31(David P. Ellerman ed. 1993).

David Ellerman, Voucher Privatization with Investment Funds: An Institutional Analysis (World Bank Pol'y Research Paper No. 1924, 1998).

EUROPEAN BANK FOR RECONSTRUCTION AND DEVELOPMENT, TRANSITION REPORT 1999 (2000).

ROMAN FRYDMAN, A NDRZEJRAPACZYNSKI \& JOHN S. EARLE, THE PRIVATIZATION PROCESS IN RUSSIA, UKRAINE AND THE BALTIC STATES 20 (1993).

Francis Fukuyama, Trust: The Social Virtues and the Creation of Prosperity (1995).

Clifford G. Gaddy \& Barry W. Ickes, Russia's Virtual Economy, ForeIGN AFF., Sept./Oct. 1998 , at 53.

Dale F. Gray, Evaluation of Taxes and Revenues from the Energy Sector in the Baltics, Russia, and Other Former Soviet Union Countries (Int'l Monetary Fund Working Paper 98/34, 1998).

Luigi Guiso, Paola Sapienza \& Luigi Zingales, The Role of Social Capital in Financial Development (Ctr. for Research in Sec. Prices Working Paper No. 511, 2000), avalable in Social Science Research Network at <http://papers.ssrn.com/paper.taf?abstract_id=209610>. 
Jonathan R. Hay \& Andrei Shleifer, Private Enforcement of Public Laws: A Theory of Legal Reform, 88 A MER. ECON. REV. (Papers \& Proceedings), 398 (1998).

FRIEDRICH A. HAYEK, 1 LAW, LEGISLATION AND LIBERTY: RULES AND ORDER (1973).

Kathryn Hendley, Barry Ickes \& Randi Ryterman, Remonetizing the Russian Economy, in RUSSIAN ENTERPRISE REFORM: POLICIES TO FURTHER THE TRANSITION 101 (Harry G. Broadman ed., 1999) (World Bank Discussion Paper No. 400).

Jeffrey M. Hertzfeld, Russian Corporate Governance: The Foreign Direct Investor's Perspective, in Organization for Economic Co-operation and Development, Corporate Governance in Russia at 6-7, (Conference Proceedings 1999) <http://www.oecd.org/daf/corporate-affairs/governance/roundtables/inRussia/1999/index.htm>

Mary Holland \& Olga Kozyr, Downsizing Russian-Style, CIS LAWNOTES (Patterson Belknap Webb \& Tyler), Mar. 1999, at 6.

INTERNATIONAL MONETARY FUND, FISCAL A FFAIRS DEPARTMENT, EVALUATIONOF TAXES AND REVENUES FROM THE ENERGY SECTOR IN THE BALTICS, RUSSIA, AND OTHER FORMER SOVIET UNION COUNTRIES (IMF Working Paper 98/34, 1998).

Jonathan Isham \& Daniel Kaufman, The Forgotten Rationale for Policy Reform: The Productivity of Investment Projects, 114 Q.J. ECON. 149 (1999).

Juliet Johnson, Russia's EmergingFinancial-Industrial Groups, 13 POST-SovIET AFF. 333 (1997).

Simon Johnson \& Andrei Shleifer, Coase v. the Coasians (working paper 1999), avalable in Social Science Research Network at <http://papers.ssrn.com/abstract_id=193776>.

Simon Johnson, John McMillan \& Christopher Woodruff, Contract Enforcement in Transition (working paper 1999).

Simon Johnson, Peter Boone, Alasdair Breach \& Eric Friedman, Corporate Governance in the Asian Financial Crisis (working paper 1999).

Steven L. Jones, William L. Megginson, Robert C. Nash \& Jeffry M. Netter, Share Issue Privatizations as Financial Means to Political and Economic Ends, 53 J. FIN. ECON. 217 (1999).

VACLAV KLAUS, RENAISSANCE: THE REBIRTH OF LIBERTY IN THE HEART OF EUROPE(1997).

Bruce Kogut \& Andrew Spicer, Institutional Technology and the Chains of Trust: Capital Markets and Privatization in Russia and the Czech Republic (working paper 1999).

Grzegorz W. Kolodko, From SHOCK to Therapy: The POlitical ECONOMY of POSTSOCIALIST TRANSFORMATION (2000).

JANOS KORNAI, THE ROAD TO A FREE ECONOMY: SHIFTING FROM A SOCIALIST SYSTEM-THE EXAMPLE OF HUNGARY (1990).

Janos Kornai, Ten Years After "The Road to a Free Economy": The Author's SelfEvaluation, working paper presented at the Annual Bank Conference on Development Economics (World Bank) 2000.

Ira W. Lieberman \& Rogi Veimetra, The Rush for State Shares in the "Klondyke" of Wild East Capitalism: Loans-for-Shares Transactions in Russia, 29 GEO. W ASH. J. INT'L L. \& ECON. 737 (1996).

William L. Megginson \& Jeffry M. Netter, From State to Market: A Survey of Empirical Studies on Privatization (N.Y. Stock Exchange Working Paper No. 98-05, 2000), 
available in Social Science Research Network at <http://papers.ssrn.com/paper.taf?abstract_id=158313>.

MCKInSEY GLOBAL INSTITUTE, UNLOCKING ECONOMIC GROWTH IN RUSSIA 24 (1999).

BRANKO MILANOVIC, INCOME, INEQUALITY, AND POVERTY DURING THE TRANSITION FROM PLANNED TO MARKET ECONOMY (World Bank 1998) <http://www.worldbank.org/research/transition/inequal.htm>.

Peter Murrell, What is Shock Therapy? What Did it Do in Poland and Russia?, 9 Pos TSOVIET AFF. 111 (1993).

Peter Murrell \& Yijiang Wang, When Privatization Should be Delayed: The Effect of Communist Legacies on Organizational and Institutional Reforms, 17 J. COMP. ECON. 385 (1993).

John Nellis, Competition and Privatization: Ownership Should Not Matter-But It Does, 4 Revista do Instituto Brasileiro De Estudos Das Relacoes DE CONCORRENCIA E DE CONSUMO 211 (1997).

John Nellis, Time to Rethink Privatization in Transition Economies?, FIN. \& DEV., June 1,1999 , at 16.

ORGANIZATION FOR ECONOMIC COOPERATION AND DEVELOPMENT, OECD ECONOMIC SURVEYS 1997-1998: CZECH REPUBLIC (1998) and OECD ECONOMIC SURVEYS 19992000: CZECH REPUBLIC (2000).

Robert Orttung, Newly Elected Regional Governors Grapple with Moscow, in ANNUAL SURVEY OF EASTERN EUROPE AND THE FORMER SOVIET UNION: 1997-THE CHALLENGES OF INTEGRATION 285 (Peter Rutland ed., 1998).

Brian Pinto, Vladimir Drebentsov \& Alexander Morozov, Give Growth and Macroeconomic Stability in Russia a Chance: Harden Budgets By Eliminating Nonpayments (working paper 2000).

Katharina Pistor, Martin Raiser \& Stanislaw Gelfer, Law and Finance in Transition Economies (Eur. Bank for Reconstr. and Dev. Working Paper No. 48, 2000), avalable in Social Science Research Network at <http://papers.ssrn.com/paper.taf?abstract_id=214648>.

A lexander Radygin, Ownership and Control of the Russian Industry, in Organization for Economic Co-operation and Development, Corporate Governance in Russia (Conference Proceedings 1999) <http://www.oecd.org/daf/corporateaffairs/governance/roundtables/in-Russia/1999/index.htm>.

Alan Reynolds, Russia and Japan in the Shadow of Tax Policy, JoBS AND CAPITAL, Summer/Fall 1998, at 50 (published by Milken Inst.).

Mark J. Roe, Backlash, 98 ColuM. L. REV. 217 (1998).

Gerard Roland, Corporate Governance Systems and Restructuring: The Lessons from the Transition Experience; working paper presented at the Annual Bank Conference on Development Economics (World Bank) 2000.

GERARD ROLAND, TRANSITION ECONOMICS: POLITICS, MARKETS AND FIRMS (forthcoming 2000).

Rozalina V. Ryvkina, What Kind of Capitalism Is Being Created in Russia?, RussiAN POL. \& L., May-June 1998, at 5.

Andrew Schwartz, The Best Laid Plan: Privatization and Neo-Liberalism in the Czech Republic (1999) (Ph.D. dissertation, Univ. of Calif. (Berkeley)) (on file with authors). Andrei Shleifer \& Robert W. Vishny, Corruption, 108 Q. J. ECON. 599 (1993). 
A NDREI SHLEIFER \& Robert W. Vishny, The GRABbing HAND: Government PATHOLOGIES AND THEIR CURES 147 (1998).

Andrei Shleifer \& Dmitry Vasiliev, Management Ownership and Russian Privatization, in 2 CORPORATE GOVERNANCE IN CENTRAL EUROPE AND RUSSIA: INSIDERS AND THE STATE 62 (Roman Frydman, Cheryl W. Gray \& Andrzej Rapaczynski eds., 1996).

A NDREI ShlEIFER \& DANIEL TREISMAN, W ITHOUT A MAP: POlitical TACTICS AND ECONOMIC REFORM IN RUSSIA (2000).

Jeffrey Sachs, Accelerating Privatization in Eastern Europe: The Case of Poland, 1 NEW EUR. L. REV. 71 (1992).

JEFFREY SACHS, POLAND's JUMP TO THE MARKET ECONOMY (1993).

Joseph E. Stiglitz, Whither Reform? Ten Years of the Transition, working paper presented at Annual Bank Conference on Development Economics (World Bank) 1999.

Pankaj Tandon, The Efficiency of Privatized Firms: Evidence and Implications (Boston Univ. working paper 1994) (on file with authors).

Jonathan Temple \& Paul A. Johnson, Social Capability and Economic Growth, 113 Q.J. ECON. 965 (1998).

Transparency International, 1999 Corruption Perceptions Index, available at <http://www.transparency.de/documents/cpi/index.html>.

JANine R. W EDEL, Collision AND Collusion: The StRANGe CASE OF W ESTERn A ID to EASTERN EUROPE, 1989-1998 (1998).

Andrew Weiss \& Georgiy Nikitin, Performance of Czech Companies by Ownership Structure (working paper 1998).

Lee S. Wolosky, Putin's Plutocrat Problem, ForeIGn AfF., Mar./Apr. 2000, at 18.

DAVID W OOdRUfF, MONEy UnMade: BARTER AND THE FATE OF RUSSIAN CAPITALisM (1999).

THE W ORLD BANK, A SSESSING A ID: W HAT W ORKS, W HAT DOESN'T, AND W HY (1998).

Paul J. Zak \& Stephen Knack, Trust and Growth (working paper 1998), available in $\mathrm{S}$ o c i a $1 \quad \mathrm{~S}$ c i e n c e $\mathrm{R}$ e s e a r c h N e t w o r k a t <http://papers.ssrn.com/paper.taf?abstract_id=136961>. 